\title{
Chave de identificação de espécies lenhosas de um trecho de Floresta Ombrófila Densa Atlântica, no Sudeste do Brasil, baseada em caracteres vegetativos
}

\author{
Catia Urbanetz ${ }^{1,2}$, Jorge Yoshio Tamashiro ${ }^{1}$ \& Luiza Sumiko Kinoshita \\ ${ }^{1}$ Departamento de Biologia Vegetal, Instituto de Biologia, \\ Universidade Estadual de Campinas - UNICAMP, \\ CP 6109, CEP 13083-970, Campinas, SP, Brasil \\ ${ }^{2}$ Autor para correspondência: Catia Urbanetz,e-mail: catia.urbanetz@gmail.com
}

URBANETZ, C., TAMASHIRO, J.Y. \& KINOSHITA, L.S. Identification key for woody species of an Atlantic Rain Forest remnant, in the Southeast of Brazil, based on vegetative characters. Biota Neotrop. 10(2): http:// www.biotaneotropica.org.br/v10n2/en/abstract?identification-key+bn00910022010.

Abstract: (Identification key for woody species of an Atlantic Rain Forest remnant, in the Southeast of Brazil, based on vegetative characters). Our main objective was to elaborate an identification key for 185 woody species from an Atlantic Rain Forest fragment in Cananéia, in the South of São Paulo State (24 $54^{\circ} \mathrm{S}$ and $\left.47^{\circ} 56^{\prime} \mathrm{W}\right)$. The key is based on morphological characters such as phyllotaxis, leaf type and shape, stipules, indument, exsudates, and glands. Images of branches, details of the reproductive and vegetative structures of 123 species were acquired to support the species identification. Most of the species (84\%) can be easily separated in the key based on vegetative characters. For the other species, reproductive characters must be also considered.

Keywords: Submontane Dense Ombrophylous Forest, dichotomous identification key.

URBANETZ, C., TAMASHIRO, J.Y. \& KINOSHITA, L.S. Chave de identificação de espécies lenhosas de um trecho de Floresta Ombrófila Densa Atlântica, no Sudeste do Brasil, baseada em caracteres vegetativos. Biota Neotrop.10(2): http://www.biotaneotropica.org.br/v10n2/pt/abstract?identification-key+bn00910022010.

Resumo: (Chave de identificação de espécies lenhosas de um trecho de Floresta Ombrófila Densa Atlântica, no Sudeste do Brasil, baseada em caracteres vegetativos). O presente trabalho objetivou a elaboração de uma chave de identificação para 185 espécies ocorrentes em um trecho de Floresta Ombrófila Densa no município de Cananéia, Sul do Estado de São Paulo (245ㄴ ' S e $47^{\circ} 56^{\prime}$ O). A chave é baseada em caracteres morfológicos tais como filotaxia, composição e formato do limbo, estípulas, indumento, exsudados, estruturas secretoras internas e externas e pontuações. Foram feitas imagens de ramos, estruturas reprodutivas e de algumas estruturas vegetativas de 123 espécies de modo a auxiliar na identificação das mesmas. A maioria das espécies (84\%) foi facilmente separada na chave e somente algumas apresentaram dificuldades para serem distinguidas, sendo necessária, nesses casos, a utilização de caracteres reprodutivos.

Palavras-chave: Floresta Ombrófila Densa Sub-Montana, chave dicotômica. 


\section{Introdução}

Estudos sobre a biodiversidade são baseados na identificação correta das espécies ocorrentes em uma área considerada. No caso de florestas, os pesquisadores muitas vezes utilizam chaves de identificação de espécies que se baseiam, em sua maioria, em caracteres reprodutivos. No entanto, a ausência de estruturas reprodutivas nos indivíduos amostrados dificulta a sua identificação. Devido à existência de ciclos reprodutivos supraanuais (Freitas \& Oliveira 2002, Newstron et al. 1994), indivíduos não férteis são encontrados no campo. Além disso, a dificuldade de obtenção de ramos em estado reprodutivo de indivíduos arbóreos de grande porte, somada à existência de estruturas reprodutivas inconspícuas, justifica a coleta de ramos vegetativos para posterior identificação. Muitos estudos de florística e fitossociologia têm se baseado também em coletas de indivíduos em estado vegetativo.

Assim, a elaboração de chaves de identificação baseadas em caracteres vegetativos é útil para pesquisas ou trabalhos técnicos que necessitem de uma identificação em tempo limitado e, além de tudo, podem ser utilizadas em qualquer período do ano. Rejmánek \& Brewer (2001) publicaram um artigo de revisão sobre chaves de espécies lenhosas de plantas tropicais baseadas em caracteres vegetativos. Dentre as chaves citadas, as de Lima et al. (1994), Rossi (1994), Guedes-Bruni et al. (1997), Duarte (2003) e Braz et al. (2004) foram elaboradas para as espécies da Mata Atlântica, sendo a de Duarte (2003) restrita à família Myrtaceae e a de Braz et al. (2004) apenas para espécies litorâneas. Os trabalhos de Mantovani et al. (1985) e Batalha et al. (1998) referem-se às espécies de cerrado e o de Coutinho (2004), ao cerradão. Spichiger (1982), Alencar (1998), Ribeiro et al. (1999) elaboraram chaves para espécies ocorrentes na Amazônia, enquanto que Torres et al. (1994) e Santos (1998) referemse às espécies que ocorrem na Floresta Estacional Semidecídua. Entre todos, o trabalho de Gentry (1993) é mais amplo onde são apresentados caracteres vegetativos como descritores de famílias e gêneros das espécies ocorrentes na Colômbia, Equador e Peru. Já Smith (1975) e Smith et al. (1996) se restringiram às espécies ocorrentes na Venezuela. Stutz (1994) enfocou apenas os indivíduos jovens de espécies que ocorrem no Paraguai.

De acordo com Edwards \& Morse (1995), a ferramenta mais comumente usada para a identificação de espécies é a chave do tipo dicotômica. A primeira chave dicotômica para plantas foi publicada em 1778, pelo botânico francês Lamarck e, desde então, tornou-se amplamente utilizada (Voss 1952).

Existem também as chaves de acesso múltiplo, computadorizadas, tais como Delta - Description Language for Taxonomy (Dallwitz et al. 1984) e Lucid (LUCIDCENTRAL). Essas chaves permitem a realização de identificações interativas em que o usuário escolhe os caracteres, evitando aqueles que não foram observados. Escolhendo-se determinado caráter, os demais táxons que não o apresentarem são eliminados da identificação. As chaves de acesso múltiplo ainda não são de ampla utilização como ferramenta de trabalho dos taxonomistas como as chaves dicotômicas (Edwards \& Morse 1995). As chaves dicotômicas levam o usuário para a observação de maior número de caracteres e podem ser impressas e utilizadas no campo.

Desta maneira, o presente estudo teve como objetivo principal a elaboração de uma chave dicotômica de identificação de espécies arbustivas e arbóreas, baseada em caracteres vegetativos, para espécies lenhosas de um trecho da Mata Atlântica litorânea no sudeste do Brasil. Além disso, foram feitas imagens de grande parte das espécies presentes, de modo a auxiliar a identificação das mesmas.

\section{Material e Métodos}

As espécies incluídas na chave são aquelas que ocorrem ao longo das trilhas de um remanescente numa área de transição de Floresta
Ombrófila Densa de Terras Baixas a Floresta Ombrófila Densa Submontana (Veloso et al., 1992), localizado na propriedade particular Fazenda Folha Larga, no município de Cananéia, na rodovia estadual SP-226, km 31, entre as coordenadas $24^{\circ} 53^{\prime} 07^{\prime \prime} \mathrm{S}$ e $47^{\circ} 55^{\prime} 58^{\prime \prime} \mathrm{O}$, Vale do Ribeira, Sul do Estado de São Paulo.

A vegetação é composta por árvores cujo dossel atinge cerca de $30 \mathrm{~m}$ e os emergentes com $35 \mathrm{~m}$. As áreas de menor altitude do remanescente $(40 \mathrm{~m})$ sofreram corte raso e foram utilizadas para $\mathrm{o}$ pastoreio até cerca de 40 anos atrás. Desde então, foram abandonadas e esses locais passaram por um processo de regeneração natural; as partes de maior altitude (entre 60 e $150 \mathrm{~m}$ ) foram conservadas, devido à dificuldade de acesso (com. pess. do atual proprietário).

O clima da área é do tipo Af - tropical úmido (Koeppen 1948). A temperatura média anual do local é de $23,4{ }^{\circ} \mathrm{C}$. A temperatura média do mês mais quente no mesmo ano foi $30,6{ }^{\circ} \mathrm{C}$ e a do mais frio, $19,8{ }^{\circ} \mathrm{C}$. A temperatura mais baixa registrada foi $9,0{ }^{\circ} \mathrm{C}$ e a mais alta, $37,0^{\circ} \mathrm{C}$. A pluviosidade média anual dos anos das coletas (2003 a 2005) foi de 1973,58 mm e a média mensal 164,47 mm (dados obtidos com o proprietário).

O solo é tipo do tipo Podzólico Vermelho Amarelo-Álico (Lepsch et al. 1999.)

O levantamento florístico da área foi realizado, totalizando 216 espécies lenhosas (Urbanetz et al. - submetido). Destas, foram incluídas na chave aquelas que ocorriam ao longo das trilhas existentes, resultando em 185 espécies. Para a confecção da chave, as espécies foram divididas em quatro grupos principais, de acordo com a ramificação do caule, composição do limbo e filotaxia. Utilizaram-se caracteres que podem ser observados a olho nu ou com auxílio de uma lupa de mão com resolução de 10 vezes.

Os termos empregados para a confecção da chave foram os utilizados em estudos taxonômicos recentes, tais como Duarte (2003), Garcia (1998), Martins et al. (1996), Wanderley et al. (2002, 2003, 2005, 2007, 2009). As obras de Ferri et al. (1981), Radford et al. (1974) e Font Quer (1985) foram eventualmente consultadas.

As famílias foram organizadas segundo a classificação de APG II (2003). Os sites do Missouri Botanical Garden (MOBOT) e International Plant Names Index (IPNI) foram consultados para conferir a grafia dos táxons e da abreviação dos nomes de seus autores, assim como Brummit \& Powell (1992).

Foram feitas imagens de ramos férteis, estruturas reprodutivas e de algumas estruturas vegetativas da maioria das espécies. As imagens foram obtidas através de câmera digital e as pranchas organizadas em ordem alfabética de família. As imagens foram citadas nas chaves, ao lado das espécies correspondentes.

\section{Resultados e Discussão}

A chave foi elaborada para 179 dicotiledôneas: espécies arbustivas (29) e espécies arbóreas (150); e seis espécies de monocotiledôneas arbóreas, distribuídas em 52 famílias e 118 gêneros (Tabela 1). Apenas três espécies estão identificadas em nível genérico.

A grande maioria das espécies pode ser facilmente separada na chave (84\%) e apenas 28 (16\%) espécies não puderam ser distinguidas com base em caracteres vegetativos devido à semelhança dos caracteres morfológicos, assim como às variações dos mesmos entre as espécies. Dentre elas estão: Guatteria australis e Rollinia sericea (mesma filotaxia e formato de folha) (Annonaceae); Vernonia puberula, Vernonia rubriramea e Vernonia beyrichii (mesmo hábito e folhas muito semelhantes) (Asteraceae); Aniba firmula, Cryptocarya saligna, Licaria armeniaca, Ocotea aciphylla e Ocotea silvestris (variação ampla de formato e tamanho de limbo) (Lauraceae); Inga edulis e Inga sessilis, Inga vera e Inga striata (Fabaceae) (folhas com presença de glândulas com formato semelhante e ausência de raque); Brosimum 
Tabela 1. Famílias e espécies presentes na chave ilustrada de identificação de espécies lenhosas de um remanescente de Floresta Ombrófila Densa Atlântica $\left(24^{\circ} 53^{\prime} 07^{\prime \prime} \mathrm{S}\right.$ e $\left.47^{\circ} 55^{\prime} 58^{\prime \prime} \mathrm{O}\right)$, Cananéia, SP. N.C.F. = não coletada fértil.

Table 1. Families and species of the illustrated identification key for woody species from an Atlantic Rain Forest remnant, Cananéia district (24 53'07' $\mathrm{S}$ and $47^{\circ} 55$ '58” W), São Paulo State, Brazil. N.C.F. = not collected fertile.

\begin{tabular}{|c|c|c|}
\hline Família/Espécie & Hábito & Número da exsicata UEC \\
\hline \multicolumn{3}{|l|}{ ANNONACEAE } \\
\hline Guatteria australis A.St.-Hil. & Arbóreo & 133.508 \\
\hline Rollinia sericea (R.E.Fr.) R.E.Fr. & Arbóreo & 132.878 \\
\hline Xylopia brasiliensis Spreng. & Arbóreo & 132.874 \\
\hline \multicolumn{3}{|l|}{ APOCYNACEAE } \\
\hline Aspidosperma olivaceum Müll.Arg. & Arbóreo & 133.534 \\
\hline Malouetia arborea (Vell.) Miers & Arbóreo & 132.839 \\
\hline \multicolumn{3}{|l|}{ AQUIFOLIACEAE } \\
\hline Ilex amara (Vell.) Loes. & Arbóreo & 133.710 \\
\hline Ilex theezans Mart. & Arbóreo & 132.849 \\
\hline \multicolumn{3}{|l|}{ ARALIACEAE } \\
\hline Schefflera angustissima (Marchal) Frodin & Arbóreo & 149.907 \\
\hline \multicolumn{3}{|l|}{ ARECACEAE } \\
\hline Astrocaryum aculeatissimum (Schott) Burret & Palmeira & - \\
\hline Attalea dubia (Mart.) Burret & Palmeira & N.C.F. \\
\hline Bactris hatschbachii Noblick ex A.J.Hend. & Palmeira & - \\
\hline Bactris setosa Mart. & Palmeira & N.C.F. \\
\hline Euterpe edulis Mart. & Palmeira & N.C.F. \\
\hline Geonoma gamiova Barb. Rodr. & Palmeira & - \\
\hline \multicolumn{3}{|l|}{ ASTERACEAE } \\
\hline Baccharis semiserrata DC. & Arbóreo & 133.362 \\
\hline Baccharis singularis (Vell.) G.M.Barroso & Arbustivo & 133.363 \\
\hline Piptocarpha macropoda (DC.) Baker & Arbóreo & 132.877 \\
\hline Vernonia argyrotrichia Sch.Bip. ex Baker & Arbustivo & - \\
\hline Vernonia beyrichii Less. & Arbustivo & - \\
\hline Vernonia petiolaris DC. & Arbóreo & 132.886 \\
\hline Vernonia puberula Less. & Arbustivo & 133.368 \\
\hline Vernonia rubriramea Mart. ex DC. & Arbustivo & - \\
\hline Vernonia scorpioides (Lam.) Pers. & Arbustivo & 133.367 \\
\hline \multicolumn{3}{|l|}{ BIGNONIACEAE } \\
\hline Jacaranda puberula Cham. & Arbóreo & 132.842 \\
\hline Tabebuia umbellata (Sond.) Sandwith & Arbóreo & 133.529 \\
\hline \multicolumn{3}{|l|}{ BORAGINACEAE } \\
\hline Cordia magnoliifolia Cham. & Arbóreo & - \\
\hline Cordia sellowiana Cham. & Arbóreo & 132.867 \\
\hline \multicolumn{3}{|l|}{ BURSERACEAE } \\
\hline Protium heptaphyllum (Aubl.) Marchand & Arbóreo & 132.888 \\
\hline \multicolumn{3}{|l|}{ CELASTRACEAE } \\
\hline Maytenus schumanniana Loes. & Arbóreo & 133.925 \\
\hline \multicolumn{3}{|l|}{ CHRYSOBALANACEAE } \\
\hline Hirtella hebeclada Moric. ex DC. & Arbóreo & 133.541 \\
\hline Licania octandra (Hoffmanns. ex Roem. \& Schult.) Kuntze & Arbóreo & 132.866 \\
\hline Parinari excelsa Sabine & Arbóreo & 133.557 \\
\hline \multicolumn{3}{|l|}{ CLETHRACEAE } \\
\hline Clethra scabra Pers. & Arbóreo & - \\
\hline \multicolumn{3}{|l|}{ CLUSIACEAE } \\
\hline Clusia criuva Cambess. & Arbóreo & 132.887 \\
\hline Garcinia gardneriana (Planch. \& Triana) Zappi & Arbóreo & 133.525 \\
\hline
\end{tabular}


Urbanetz, C. et al.

Tabela 1. Continuação...

\begin{tabular}{|c|c|c|}
\hline Família/Espécie & Hábito & Número da exsicata UEC \\
\hline \multicolumn{3}{|l|}{ CUNONIACEAE } \\
\hline Weinmannia paullinifolia Pohl ex Ser. & Arbóreo & 149.416 \\
\hline \multicolumn{3}{|l|}{ ELAEOCARPACEAE } \\
\hline Sloanea guianensis (Aubl.) Benth. & Arbóreo & 132.889 \\
\hline \multicolumn{3}{|l|}{ ERYTHROXYLACEAE } \\
\hline Erythroxylum cuspidifolium Mart. & Arbóreo & 133.540 \\
\hline Actinostemon concolor (Spreng.) Müll.Arg. & Arbóreo & 133.905 \\
\hline Alchornea glandulosa Poepp. & Arbóreo & 132.829 \\
\hline Alchornea triplinervia (Spreng.) Müll.Arg. & Arbóreo & 132.838 \\
\hline Aparisthmium cordatum (A.Juss.) Baill. & Arbóreo & 133.547 \\
\hline Maprounea guianensis Aubl. & Arbóreo & 133.499 \\
\hline Pera glabrata (Schott) Poepp. ex Baill. & Arbóreo & 133.530 \\
\hline Tetrorchidium rubrivenium Poepp. & Arbóreo & 132.879 \\
\hline \multicolumn{3}{|l|}{ FABACEAE } \\
\hline Andira fraxinifolia Benth. & Arbóreo & 133.522 \\
\hline Balizia pedicellaris (DC.) Barneby \& J.W. Grimes & Arbóreo & N.C.F. \\
\hline Centrolobium tomentosum Guill. ex Benth. & Arbóreo & - \\
\hline Copaifera trapezifolia Hayne & Arbóreo & N.C.F. \\
\hline Dahlstedtia pinnata (Benth.) Malme & Arbóreo & 133.527 \\
\hline Hymenaea courbaril $\mathrm{L}$. & Arbóreo & - \\
\hline Inga bullata Benth. & Arbóreo & 132.883 \\
\hline Inga edulis Mart. & Arbóreo & 132.832 \\
\hline Inga lanceifolia Benth. & Arbóreo & 133.482 \\
\hline Inga sessilis (Vell.) Mart. & Arbóreo & 132.834 \\
\hline Inga striata Benth. & Arbóreo & - \\
\hline Inga vera Willd. & Arbóreo & 133.484 \\
\hline Pterocarpus rohrii Vahl & Arbóreo & 132.884 \\
\hline Schizolobium parahyba (Vell.) S.F.Blake & Arbóreo & 133.713 \\
\hline Sclerolobium denudatum Vogel & Arbóreo & 133.936 \\
\hline Actinostemon concolor (Spreng.) Müll.Arg. & Arbóreo & 133.905 \\
\hline Alchornea glandulosa Poepp. & Arbóreo & 132.829 \\
\hline Alchornea triplinervia (Spreng.) Müll.Arg. & Arbóreo & 132.838 \\
\hline Aparisthmium cordatum (A.Juss.) Baill. & Arbóreo & 133.547 \\
\hline Maprounea guianensis Aubl. & Arbóreo & 133.499 \\
\hline Pera glabrata (Schott) Poepp. ex Baill. & Arbóreo & 133.530 \\
\hline Tetrorchidium rubrivenium Poepp. & Arbóreo & 132.879 \\
\hline \multicolumn{3}{|l|}{ FABACEAE } \\
\hline Andira fraxinifolia Benth. & Arbóreo & 133.522 \\
\hline Balizia pedicellaris (DC.) Barneby \& J.W. Grimes & Arbóreo & N.C.F. \\
\hline Centrolobium tomentosum Guill. ex Benth. & Arbóreo & - \\
\hline Copaifera trapezifolia Hayne & Arbóreo & N.C.F. \\
\hline Dahlstedtia pinnata (Benth.) Malme & Arbóreo & 133.527 \\
\hline Hymenaea courbaril L. & Arbóreo & - \\
\hline Inga bullata Benth. & Arbóreo & 132.883 \\
\hline Inga edulis Mart. & Arbóreo & 132.832 \\
\hline Inga lanceifolia Benth. & Arbóreo & 133.482 \\
\hline Inga sessilis (Vell.) Mart. & Arbóreo & 132.834 \\
\hline Inga striata Benth. & Arbóreo & - \\
\hline Inga vera Willd. & Arbóreo & 133.484 \\
\hline Pterocarpus rohrii Vahl & Arbóreo & 132.884 \\
\hline Schizolobium parahyba (Vell.) S.F.Blake & Arbóreo & 133.713 \\
\hline Sclerolobium denudatum Vogel & Arbóreo & 133.936 \\
\hline Senna multijuga (Rich.) H.S.Irwin \& Barneby & Arbóreo & 133.514 \\
\hline Senna silvestris (Vell.) H.S.Irwin \& Barneby & Arbóreo & 149.956 \\
\hline Swartzia submarginata (Benth.) Mansano & Arbóreo & - \\
\hline Zollernia ilicifolia (Brogn.) Vogel & Arbóreo & N.C.F. \\
\hline
\end{tabular}


Tabela 1. Continuação...

\begin{tabular}{|c|c|c|}
\hline Família/Espécie & Hábito & Número da exsicata UEC \\
\hline \multicolumn{3}{|l|}{ HUMIRIACEAE } \\
\hline Vantanea compacta (Schnizl.) Cuatrec. & Arbóreo & 149.911 \\
\hline \multicolumn{3}{|l|}{ LACISTEMATACEAE } \\
\hline Lacistema lucidum Schnizl. & Arbóreo & 133.903 \\
\hline \multicolumn{3}{|l|}{ LAURACEAE } \\
\hline Aniba firmula (Nees \& Mart.) Mez & Arbóreo & 133.512 \\
\hline Cryptocarya saligna $\mathrm{Mez}$ & Arbóreo & 133.707 \\
\hline Licaria armeniaca (Nees) Kosterm. & Arbóreo & 133.543 \\
\hline Nectandra oppositifolia Nees \& Mart. & Arbóreo & 133.898 \\
\hline Ocotea aciphylla (Nees) Mez & Arbóreo & - \\
\hline Ocotea daphnifolia (Meisn.) Mez & Arbóreo & 133.706 \\
\hline Ocotea diospyrifolia (Meisn.) Mez & Arbóreo & 133.372 \\
\hline Ocotea nectandrifolia $\mathrm{Mez}$ & Arbóreo & 133.371 \\
\hline Ocotea silvestris Vattimo-Gil & Arbóreo & 132.830 \\
\hline Rhodostemonodaphne macrocalyx (Meisn.) Rohwer ex Madriñan & Arbóreo & 133.370 \\
\hline \multicolumn{3}{|l|}{ MALPIGHIACEAE } \\
\hline Byrsonima ligustrifolia A.Juss. & Arbóreo & 132.892 \\
\hline \multicolumn{3}{|l|}{ MALVACEAE } \\
\hline Pseudobombax grandiflorum (Cav.) A.Robyns & Arbóreo & - \\
\hline \multicolumn{3}{|l|}{ MELASTOMATACEAE } \\
\hline Leandra scabra DC. & Arbustivo & - \\
\hline Leandra cf. dasytricha (A.Gray) Cogn. & Arbóreo & - \\
\hline Leandra cf. dubia DC. & Arbustivo & 133.361 \\
\hline Leandra cf. nianga Cogn. & Arbustivo & 149.905 \\
\hline Miconia cabussu Hoehne & Arbóreo & 149.910 \\
\hline Miconia cinerascens Miq. & Arbóreo & - \\
\hline Miconia cinnamomifolia (DC.) Naudin & Arbóreo & 133.476 \\
\hline Miconia cubatanensis Hoehne & Arbóreo & 149.958 \\
\hline Miconia dodecandra Cogn. & Arbóreo & 149.947 \\
\hline Miconia hymenonervia (Raddi) Cogn. & Arbóreo & 149.954 \\
\hline Miconia rigidiuscula Cogn. & Arbóreo & 149.959 \\
\hline Miconia saldanhaei Cogn. & Arbustivo & 133.475 \\
\hline \multicolumn{3}{|l|}{ MELASTOMATACEAE } \\
\hline Tibouchina arborea Cogn. & Arbóreo & 149.922 \\
\hline Tibouchina mutabilis Cogn. & Arbóreo & 149.920 \\
\hline Tibouchina weddellii Cogn. & Arbóreo & - \\
\hline \multicolumn{3}{|l|}{ MELIACEAE } \\
\hline Cabralea canjerana (Vell.) Mart. & Arbóreo & 132.873 \\
\hline Cedrela fissilis Vell. & Arbóreo & 133.552 \\
\hline Guarea macrophylla Vahl & Arbóreo & 132.831 \\
\hline \multicolumn{3}{|l|}{ MONIMIACEAE } \\
\hline Mollinedia schottiana (Spreng.) Perkins & Arbustivo & 133.496 \\
\hline Mollinedia boracensis Peixoto & Arbustivo & 132.841 \\
\hline \multicolumn{3}{|l|}{ MORACEAE } \\
\hline Brosimum glaziovii Taub. & Arbóreo & - \\
\hline Brosimum guianense (Aubl.) Huber & Arbóreo & - \\
\hline Ficus pulchella Schott ex Spreng. & Arbóreo & 133.373 \\
\hline \multicolumn{3}{|l|}{ MYRISTICACEAE } \\
\hline Virola bicuhyba (Schott ex Spreng) Warb. & Arbóreo & 132.868 \\
\hline Virola gardneri (A.DC.) Warb. & Arbóreo & 133.941 \\
\hline \multicolumn{3}{|l|}{ MYRSINACEAE } \\
\hline Ardisia guianensis (Aubl.) Mez & Arbóreo & 133.532 \\
\hline Myrsine ferruginea (Ruiz \& Pav.) Spreng. & Arbóreo & 133.708 \\
\hline Myrsine guianensis (Aubl.) Kuntze & Arbóreo & 132.847 \\
\hline \multicolumn{3}{|l|}{ MYRTACEAE } \\
\hline Blepharocalyx salicifolius (Kunth) O.Berg & Arbustivo & 133.516 \\
\hline Calyptranthes fusiformis M.L.Kawas. & Arbóreo & 133.723 \\
\hline
\end{tabular}


Tabela 1. Continuação...

\begin{tabular}{|c|c|c|}
\hline Família/Espécie & Hábito & Número da exsicata UEC \\
\hline \multicolumn{3}{|l|}{ MYRTACEAE } \\
\hline Calyptranthes grandifolia O.Berg & Arbóreo & 133.722 \\
\hline Calyptranthes lucida Mart. ex DC. & Arbóreo & 133.517 \\
\hline Calyptranthes strigipes O.Berg & Arbóreo & 149.918 \\
\hline Campomanesia guaviroba (DC.) Kiaersk. & Arbóreo & 133.725 \\
\hline Eugenia acutata Miq. & Arbóreo & 133.731 \\
\hline Eugenia bocainensis Mattos & Arbustivo & 133.726 \\
\hline Eugenia brasiliensis Lam. & Arbóreo & 133.963 \\
\hline Eugenia copacabanensis Kiaersk. & Arbóreo & 133.962 \\
\hline Eugenia cuprea Nied. & Arbustivo & 133.486 \\
\hline Eugenia mosenii (Kausel) Sobral & Arbóreo & 133.732 \\
\hline Eugenia multicostata D.Legrand & Arbóreo & 133.727 \\
\hline Eugenia neoaustralis Sobral & Arbóreo & 149.925 \\
\hline Eugenia umbelliflora O.Berg & Arbóreo & N.C.F. \\
\hline Gomidesia flagellaris D. Legrand & Arbóreo & 133.716 \\
\hline Gomidesia schaueriana O.Berg & Arbóreo & 133.720 \\
\hline Gomidesia spectabilis (DC.) O.Berg & Arbóreo & - \\
\hline Marlierea eugeniopsoides (D.Legrand \& Kausel) D.Legrand & Arbóreo & 133.956 \\
\hline Marlierea tomentosa Cambess. & Arbóreo & 133.721 \\
\hline Myrcia aff. grandiflora Cambess. & Arbustivo & - \\
\hline Myrcia heringii D. Legrand & Arbustivo & - \\
\hline Myrcia multiflora (Lam.) DC. & Arbóreo & 133.966 \\
\hline Myrcia pubipetala Miq. & Arbóreo & 133.969 \\
\hline Myrcia splendens (Sw.) DC. & Arbóreo & 132.855 \\
\hline Myrcia stictophylla (O.Berg) N.J.E.Silveira & Arbóreo & 133.968 \\
\hline Psidium cattleianum Sabine & Arbóreo & 133.728 \\
\hline \multicolumn{3}{|l|}{ NYCTAGINACEAE } \\
\hline Guapira opposita (Vell.) Reitz & Arbóreo & 133.498 \\
\hline Neea schwackeana Heimerl & Arbustivo & 133.535 \\
\hline \multicolumn{3}{|l|}{ OCHNACEAE } \\
\hline Ouratea parviflora (DC.) Baill. & Arbóreo & 133.938 \\
\hline \multicolumn{3}{|l|}{ OLACACEAE } \\
\hline Heisteria silvianii Schwacke & Arbóreo & 132.871 \\
\hline Tetrastylidium grandifolium (Baill.) Sleumer & Arbóreo & 133.553 \\
\hline \multicolumn{3}{|l|}{ PHYLLANTHACEAE } \\
\hline Hieronyma alchorneoides Allemão & Arbóreo & 133.536 \\
\hline \multicolumn{3}{|l|}{ PHYLLANTHACEAE } \\
\hline Richeria grandis Vahl & Arbóreo & 132.863 \\
\hline \multicolumn{3}{|l|}{ PIPERACEAE } \\
\hline Ottonia martiana Miq. & Arbustivo & 133.554 \\
\hline Piper cernuum Vell. & Arbustivo & 133.944 \\
\hline Piper aduncum $\mathrm{L}$. & Arbustivo & 133.953 \\
\hline \multicolumn{3}{|l|}{ POLYGONACEAE } \\
\hline Coccoloba mosenii Lindau & Arbóreo & 132.852 \\
\hline \multicolumn{3}{|l|}{ ROSACEAE } \\
\hline Prunus myrtifolia (L.) Urb. & Arbóreo & 132.885 \\
\hline \multicolumn{3}{|l|}{ RUBIACEAE } \\
\hline Chomelia catharinae (L.B.Sm. \& Downs) Steyerm. & Arbustivo & 133.524 \\
\hline Faramea montevidensis (Cham. \& Schltdl.) DC. & Arbóreo & 133.358 \\
\hline Faramea multiflora A.Rich. ex DC. & Arbóreo & 133.380 \\
\hline Ixora heterodoxa Müll.Arg. & Arbóreo & 133.523 \\
\hline Posoqueria latifolia (Rudge) Roem. \& Schult. & Arbóreo & 133.489 \\
\hline Psychotria birotula L.B.Sm. \& Downs & Arbustivo & 133.378 \\
\hline Psychotria carthagenensis Jacq. & Arbóreo & - \\
\hline Psychotria gracilenta Müll.Arg. & Arbustivo & - \\
\hline Psychotria hoffmannseggiana Müll.Arg. & Arbustivo & 132.860 \\
\hline Psychotria laciniata Vell. & Arbóreo & 133.558 \\
\hline Psychotria leiocarpa Cham. \& Schltdl. & Arbóreo & 133.375 \\
\hline
\end{tabular}


Tabela 1. Continuação...

\begin{tabular}{|c|c|c|}
\hline Família/Espécie & Hábito & Número da exsicata UEC \\
\hline \multicolumn{3}{|l|}{ RUBIACEAE } \\
\hline Psychotria mapourioides DC. & Arbóreo & 132.891 \\
\hline Psychotria nuda (Cham. \& Schltdl.) Wawra & Arbóreo & - \\
\hline Rudgea recurva Müll.Arg. & Arbóreo & 133.383 \\
\hline \multicolumn{3}{|l|}{ RUTACEAE } \\
\hline Esenbeckia grandiflora Mart. & Arbóreo & 132.869 \\
\hline Zanthoxylum rhoifolium Lam. & Arbóreo & 133.561 \\
\hline \multicolumn{3}{|l|}{ SALICACEAE } \\
\hline Casearia sylvestris $\mathrm{Sw}$. & Arbóreo & 133.715 \\
\hline \multicolumn{3}{|l|}{ SAPINDACEAE } \\
\hline Cupania oblongifolia Camb. & Arbóreo & 133.902 \\
\hline Matayba intermedia Radlk. & Arbóreo & 133.556 \\
\hline \multicolumn{3}{|l|}{ SAPOTACEAE } \\
\hline Chrysophyllum flexuosum Mart. & Arbóreo & 133.354 \\
\hline Diploon cuspidatum (Hoehne) Cronquist & Arbóreo & 133.497 \\
\hline Ecclinusa ramiflora Mart. & Arbóreo & 133.493 \\
\hline Manilkara subsericea (Mart.) Dubard & Arbóreo & 149.919 \\
\hline Pradosia lactescens (Vell.) Radlk. & Arbóreo & 149.908 \\
\hline \multicolumn{3}{|l|}{ SOLANACEAE } \\
\hline Brunfelsia pauciflora (Cham. \& Schltdl.) Benth. & Arbustivo & 133.342 \\
\hline Cestrum sessiliflorum Schott ex Sendt. & Arbustivo & 133.531 \\
\hline Solanum pseudoquina A.St.-Hil. & Arbóreo & 133.555 \\
\hline Solanum undulatum Dunal & Arbustivo & 132.837 \\
\hline Solanum swartzianum Roem. \& Schult. & Arbóreo & 133.488 \\
\hline \multicolumn{3}{|l|}{ SYMPLOCACEAE } \\
\hline Symplocos laxiflora Benth. & Arbóreo & 133.520 \\
\hline \multicolumn{3}{|l|}{ THYMELAEACEAE } \\
\hline Daphnopsis schwackeana Taub. & Arbustivo & 132.850 \\
\hline \multicolumn{3}{|l|}{ URTICACEAE } \\
\hline Cecropia glaziovi Snethl. & Arbóreo & - \\
\hline Cecropia pachystachya Trécul. & Arbóreo & - \\
\hline Coussapoa microcarpa (Schott) Rizzini & Arbóreo & 132.864 \\
\hline Pourouma guianensis Aubl. & Arbóreo & 133.932 \\
\hline \multicolumn{3}{|l|}{ VERBENACEAE } \\
\hline Aegiphila sellowiana Cham. & Arbóreo & N.C.F. \\
\hline Citharexylum myrianthum Cham. & Arbóreo & 133.500 \\
\hline Vitex polygama Cham. & Arbóreo & 133.494 \\
\hline \multicolumn{3}{|l|}{ VOCHYSIACEAE } \\
\hline Callisthene kuhlmanii H.F.Martins & Arbóreo & 133.940 \\
\hline Vochysia bifalcata Warm. & Arbóreo & 133.943 \\
\hline
\end{tabular}

glaziovii e Brosimum guianensis (mesma textura e nervação das folhas) (Moraceae); Miconia cinerascens e Miconia dodecandra (mesmo tipo de nervação e tamanho de folha) (Melastomataceae); Mollinedia boracensis e Mollinedia schottiana (Monimiaceae); Eugenia neoaustralis e Eugenia copacabanensis, Eugenia cuprea e Gomidesia flagellaris (nervação da folha semelhante) (Myrtaceae); Psychotria carthagenensis e Psychotria mapourioides (formato de limbo semelhante e presença do mesmo tipo de domácias nas folhas), Psychotria laciniata e Psychotria nuda (mesmo formato e textura de folha) (Rubiaceae). Estas espécies pertencem, em sua maioria, às famílias mais ricas (Asteraceae, Lauraceae, Leguminosae, Myrtaceae e Rubiaceae) e gêneros com o maior número de espécies (Eugenia, Gomidesia, Inga, Miconia, Ocotea, Psychotria e Vernonia). Nestes casos, torna-se necessário o uso de caracteres reprodutivos para sua identificação.

Algumas espécies apareceram mais de uma vez na chave por apresentarem variação em alguns caracteres, como Clethra scabra, Lacistema lucidum, Tetrorchidium rubrivenium, Vernonia puberula, Vernonia rubriramea, Vernonia beyrichii (folhas com margem lisa e serreada); e Miconia cubatanensis (folhas com todos os pares de nervuras secundárias basais quanto folhas com pelo menos um par de nervuras secundárias suprabasais). Deve ser destacado que Esenbeckia grandiflora possui folhas compostas unifolioladas e que poderiam ser confundidas com folhas simples; e pode apresentar ainda filotaxia oposta, suboposta e alterna. Dessa forma, esta espécie está presente nas três chaves de plantas com caule ramificado. Por apresentar látex em quantidade insuficiente para que possa ser notado, Heisteria silvianii foi incluída nos grupos de plantas com e sem látex.

Foram feitas 31 pranchas com imagens de 123 espécies (Figuras 1-31). As pranchas apresentam fotos de ramos, flores e frutos, além de detalhes de algumas estruturas vegetativas importantes para a identificação de algumas delas, tais como de tronco (Figuras 12c, 20d, 28c e 30a), estípula (Figura 26d), pecíolo (Figura 21d), porção distal da raque (Figuras 17d e 28d) e nectário extra-floral (Figuras 11a e 12a).

Acreditamos que tanto a chave quanto as ilustrações poderão ser úteis para a identificação de espécies em outras áreas de Mata Atlântica, uma vez que há espécies que possuem ampla distribuição e ocorrem em outras localidades (Urbanetz 2005). 
Urbanetz, C. et al.
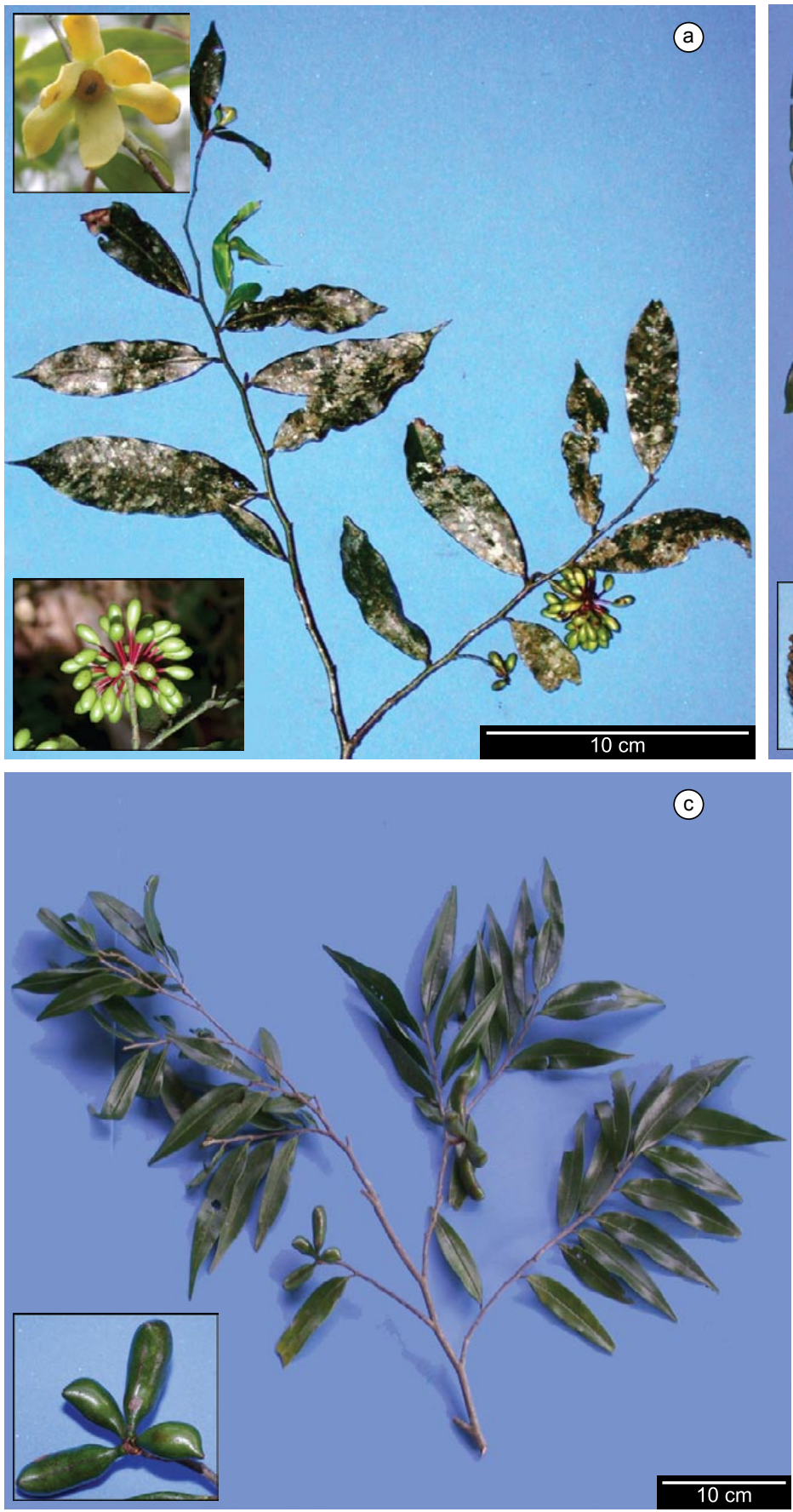
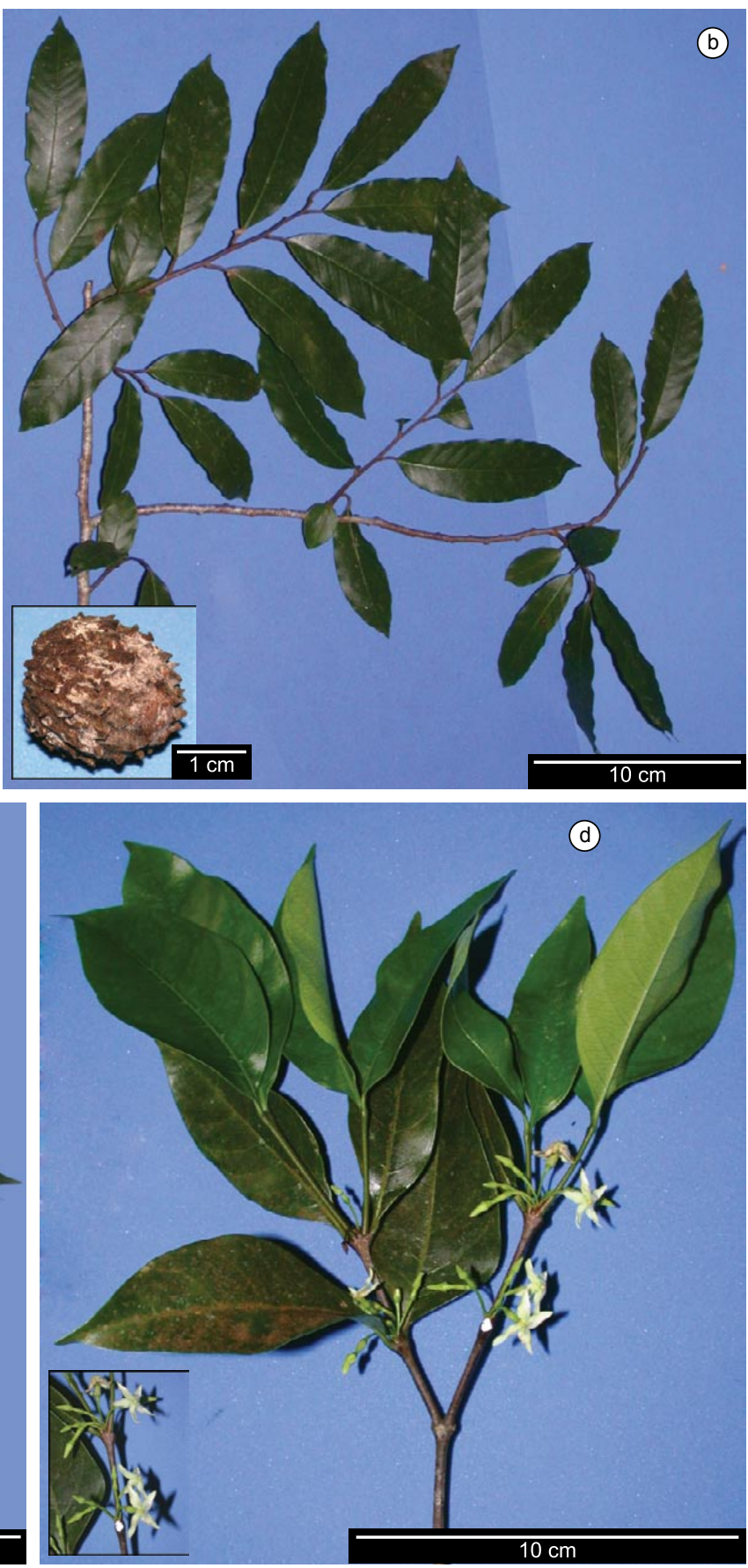

Figura 1. Annonaceae: a) Guatteria australis (C. Urbanetz 235), em destaque detalhes da flor e do fruto; b) Rollinia sericea (C. Urbanetz 132), em destaque detalhe dos frutos; c) Xylopia brasiliensis (C. Urbanetz 163), em destaque detalhe dos frutos imaturos. Apocynaceae: d) Malouetia arborea (C. Urbanetz 177), em destaque detalhe das flores.

Figure 1. Annonaceae: a) Guatteria australis (C. Urbanetz 235), flower and fruit in detail; b) Rollinia sericea (C. Urbanetz 132), fruits in detail; c) Xylopia brasiliensis (C. Urbanetz 163), immature fruits in detail. Apocynaceae: d) Malouetia arborea (C. Urbanetz 177), flowers in detail. 
Chave de identificação de espécies lenhosas
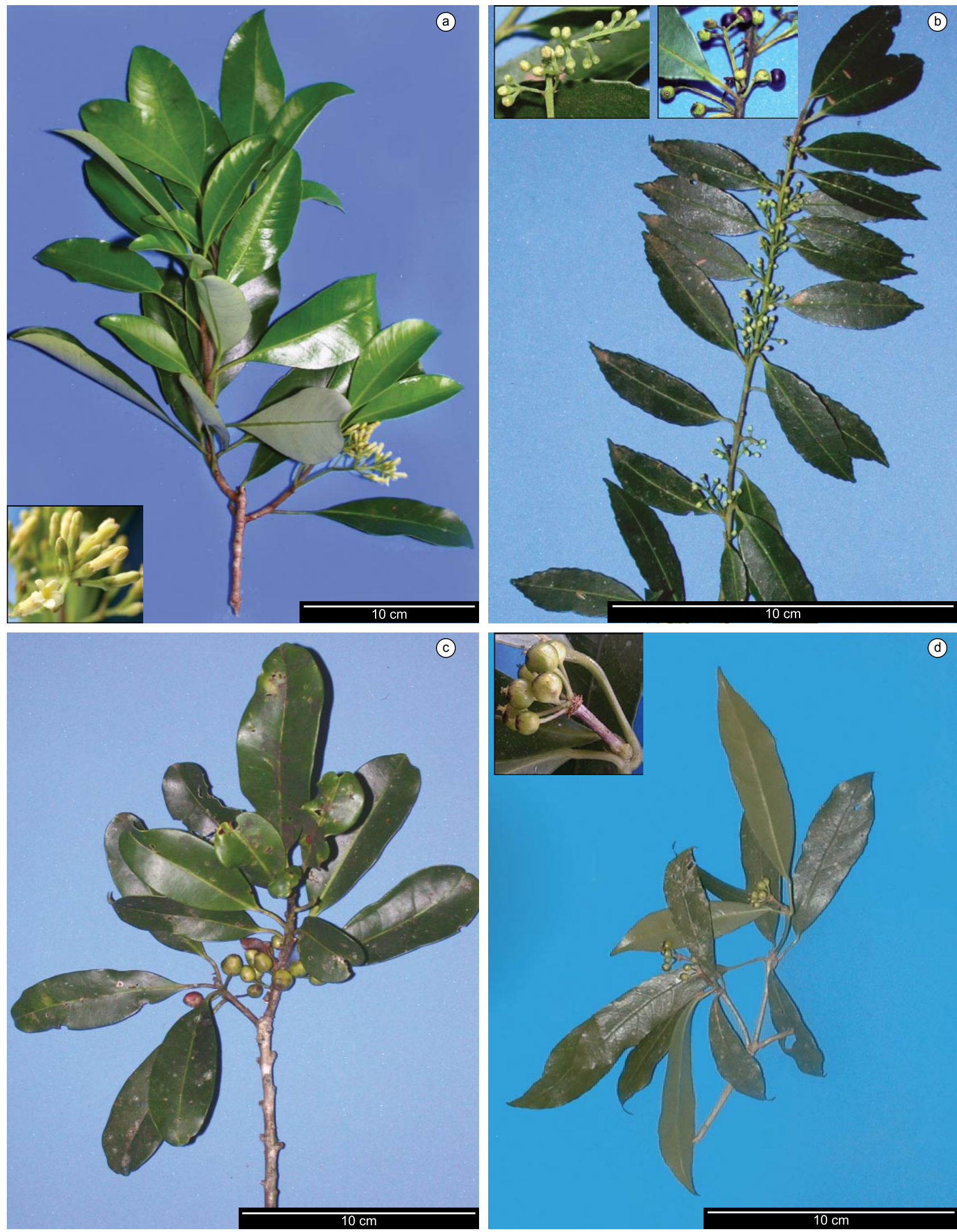

Figura 2. Apocynaceae: a) Aspidosperma olivaceum (C. Urbanetz 271), em destaque detalhe das flores. Aquifoliaceae: b) Ilex amara (C. Urbanetz 360), em destaque detalhes da inflorescência e dos frutos; c) Ilex theezans (C. Urbanetz 85). Araliaceae: d) Dendropanax monogynus (C. Urbanetz 352), em destaque detalhe dos frutos.

Figure 2. Apocynaceae: a) Aspidosperma olivaceum (C. Urbanetz 271), flowers in detail. Aquifoliaceae: b) Ilex amara (C. Urbanetz 360), inflorescence and fruits in detail; c) Ilex theezans (C. Urbanetz 85). Araliaceae: d) Dendropanax monogynus (C. Urbanetz 352), fruits in detail. 
Urbanetz, C. et al.
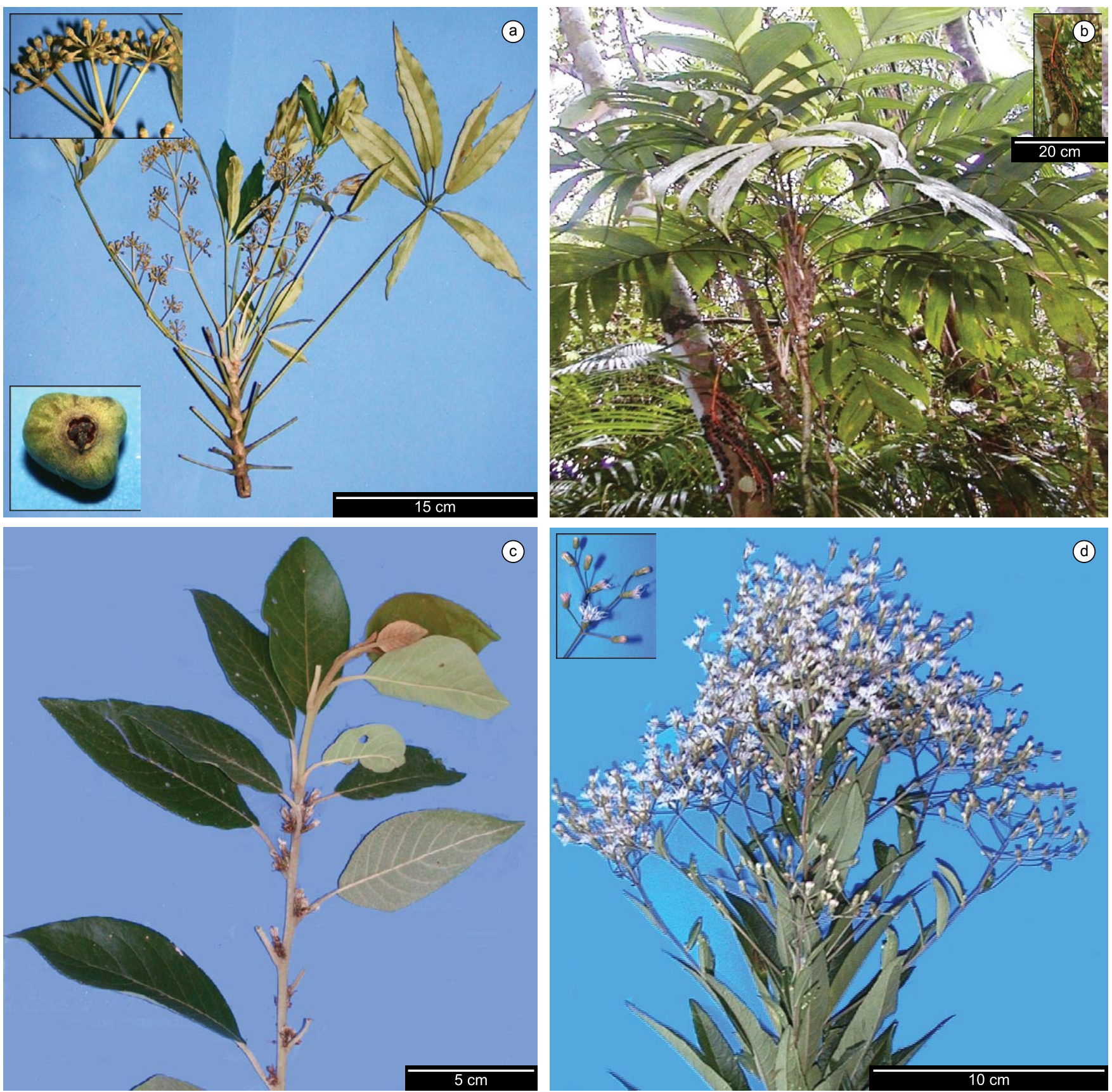

Figura 3. Araliaceae: a) Schefflera angustissima (C. Urbanetz 139), em destaque detalhes da inflorescência e do fruto. Arecaceae: b) Geonoma gamiova (C. Urbanetz 64), em destaque detalhe dos frutos. Asteraceae: c) Pitocarpha macropoda (C. Urbanetz 147); d) Vernonia beyrichii (C. Urbanetz 414), em destaque detalhe da inflorescência.

Figure 3. Araliaceae: a) Schefflera angustissima (C. Urbanetz 139), inflorescence and fruit in detail. Arecaceae: b) Geonoma gamiova (C. Urbanetz 64), fruits in detail. Asteraceae: c) Pitocarpha macropoda (C. Urbanetz 147); d. Vernonia beyrichii (C. Urbanetz 414), inflorescence in detail. 

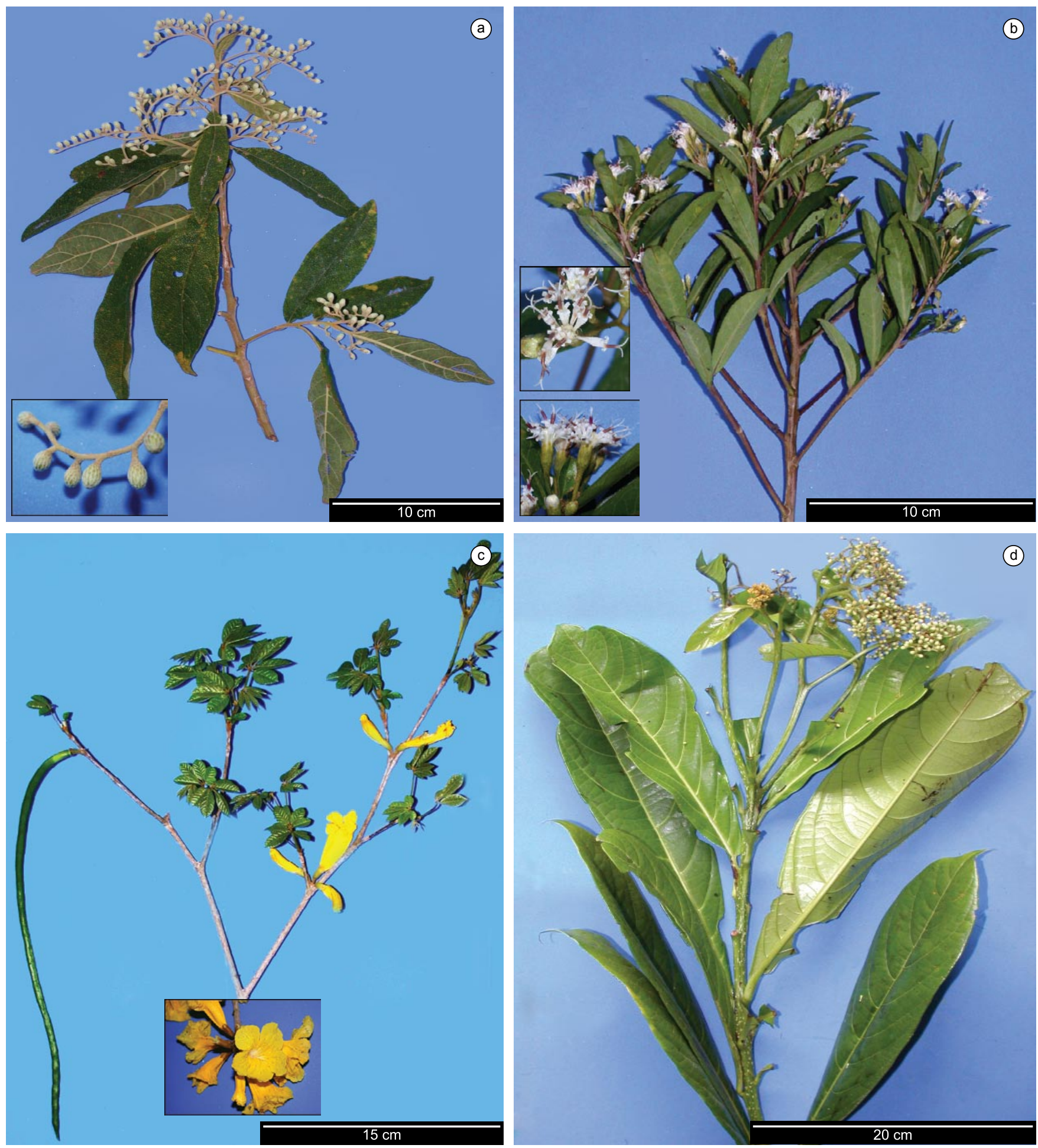

Figura 4. Asteraceae: a) Vernonia petiolaris (C. Urbanetz 159), em destaque detalhe da inflorescência; b) Vernonia puberula (C. Urbanetz 126), em destaque detalhes dos capítulos e das flores. Bignoniaceae: c) Tabebuia chrysotricha (C. Urbanetz 128), em detaque detalhe das flores. Boraginaceae: d) Cordia magnoliifolia (C. Urbanetz 391).

Figure 4. Asteraceae: a) Vernonia petiolaris (C. Urbanetz 159), inflorescence in detail; b) Vernonia puberula (C. Urbanetz 126), heads and flowers in detail. Bignoniaceae: c) Tabebuia chrysotricha (C. Urbanetz 128), flowers in detail. Boraginaceae: d) Cordia magnoliifolia (C. Urbanetz 391). 
Urbanetz, C. et al.
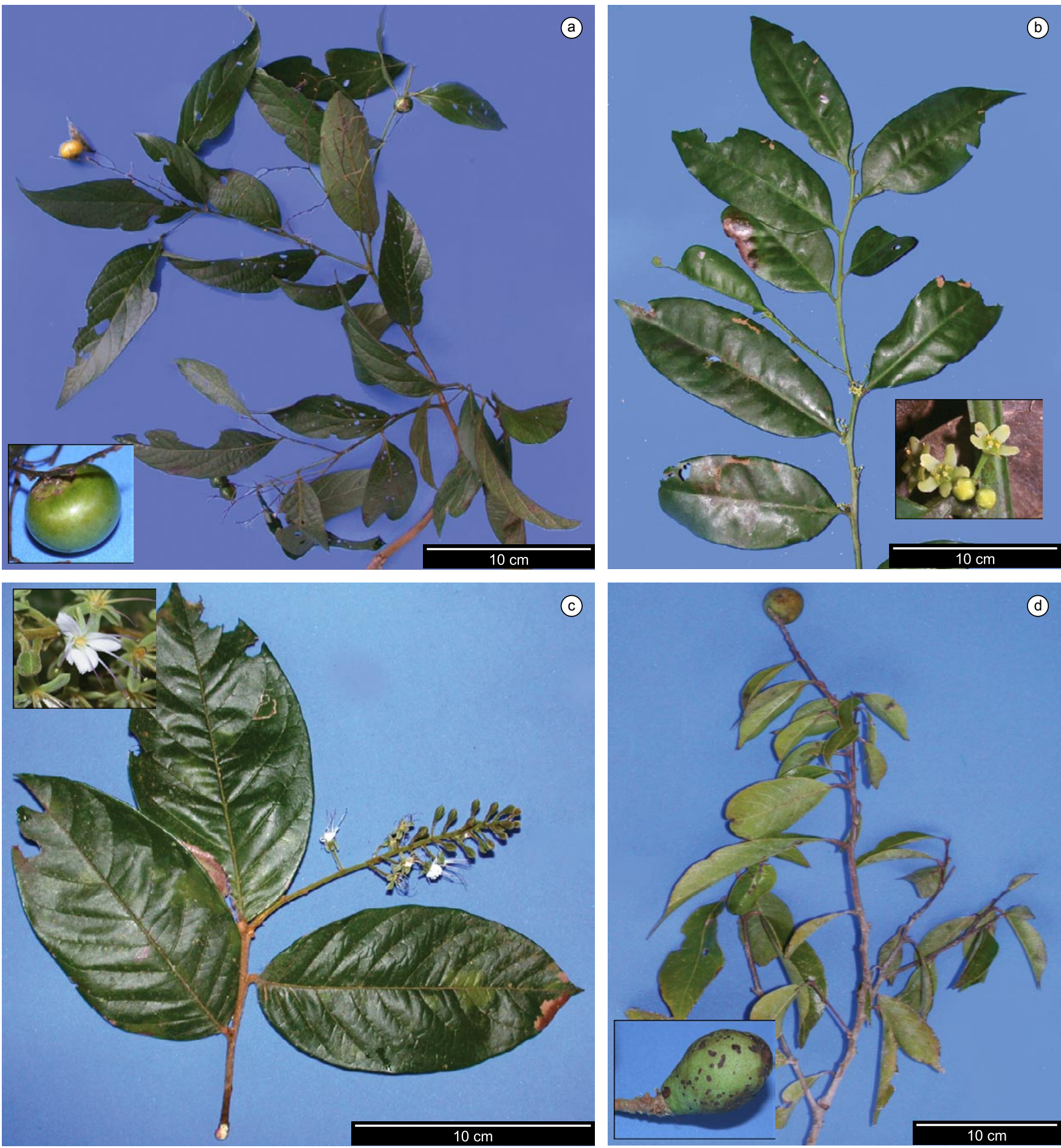

Figura 5. Boraginaceae: a) Cordia sellowiana (C. Urbanetz 140), em destaque detalhe do fruto. Celastraceae: b) Maytenus schumanniana (C. Urbanetz 232), em destaque detalhe das flores. Chrysobalanaceae: c) Hirtella hebeclada (C. Urbanetz 345), em destaque detalhe da flor; d) Licania octandra (C. Urbanetz 143), em destaque detalhe do fruto.

Figure 5. Boraginaceae: a) Cordia sellowiana (C. Urbanetz 140), fruit in detail. Celastraceae: b) Maytenus schumanniana (C. Urbanetz 232), flowers in detail. Chrysobalanaceae: c) Hirtella hebeclada (C. Urbanetz 345), flower in detail; d) Licania octandra (C. Urbanetz 143), fruit in detail. 
Chave de identificação de espécies lenhosas
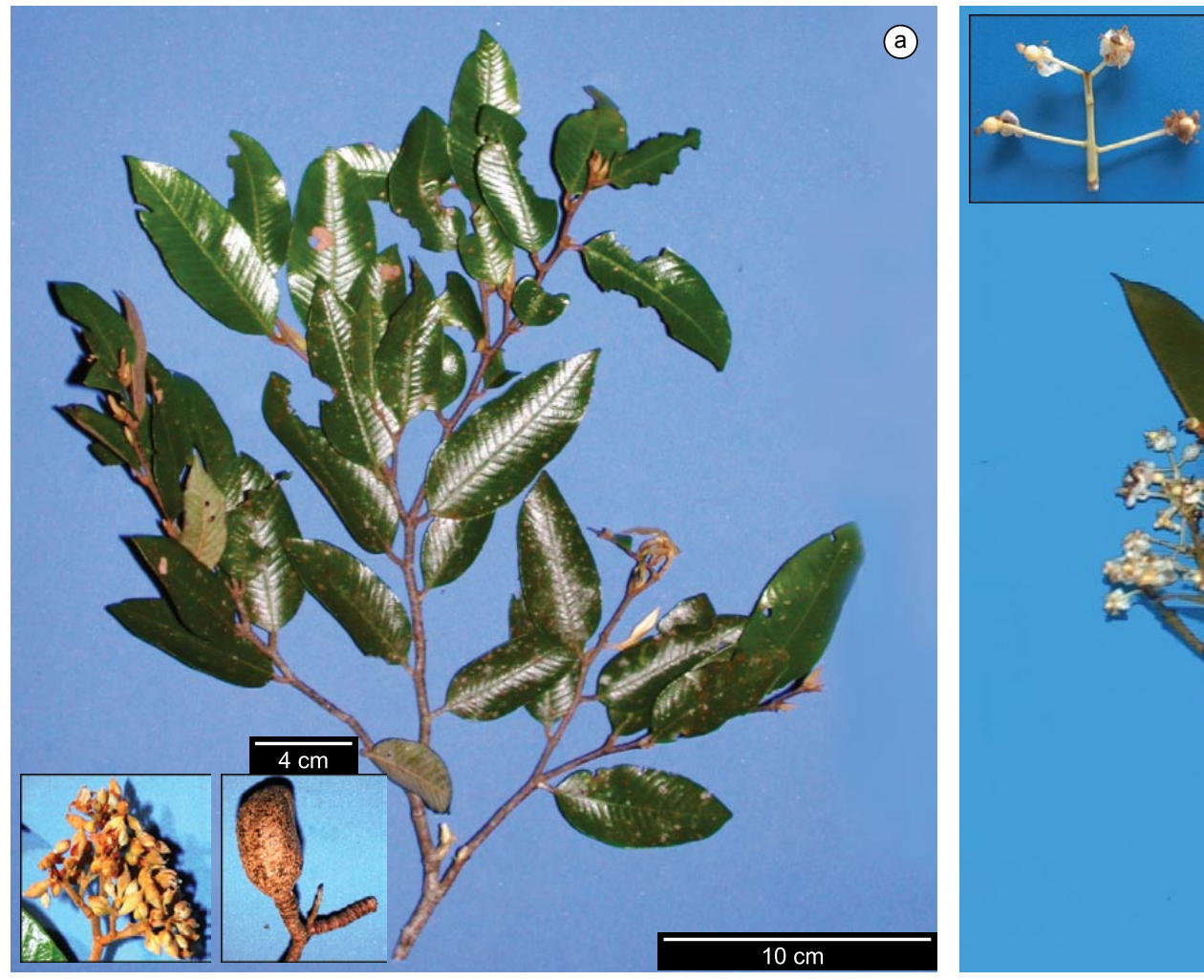

(b)

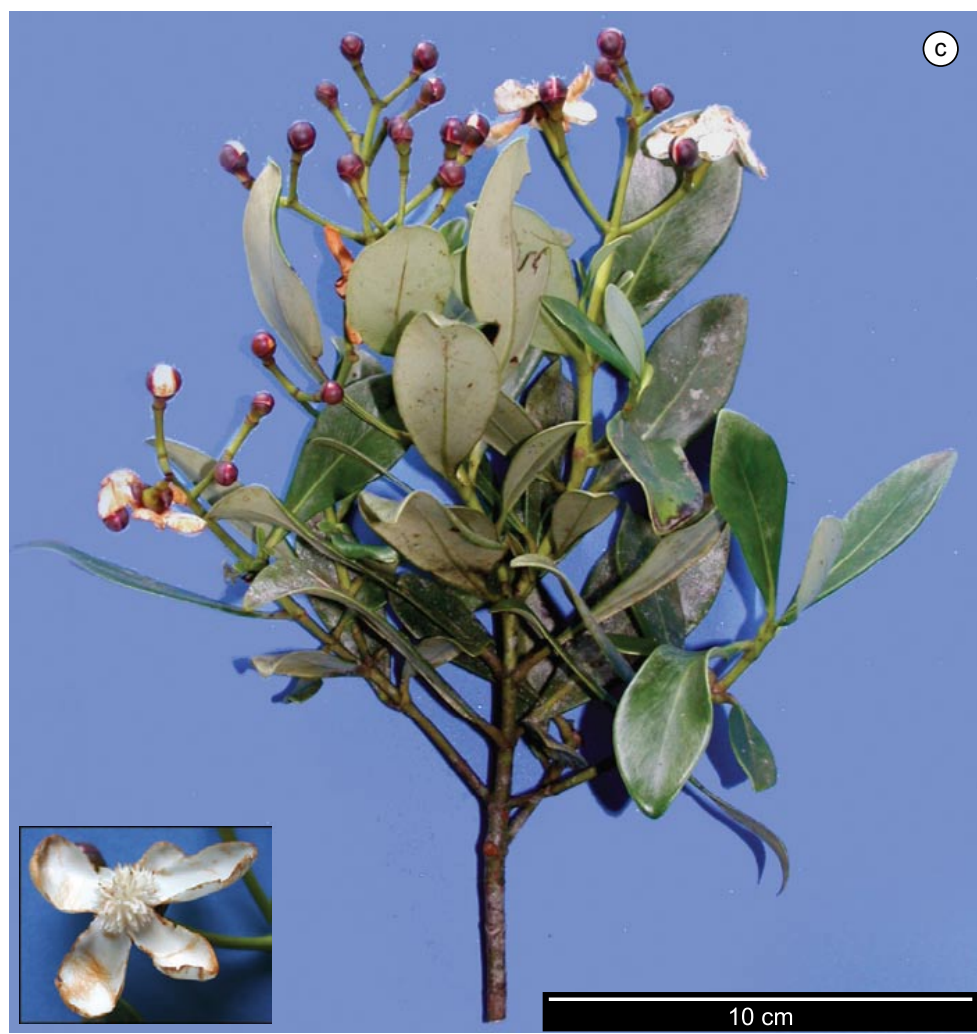

(c)

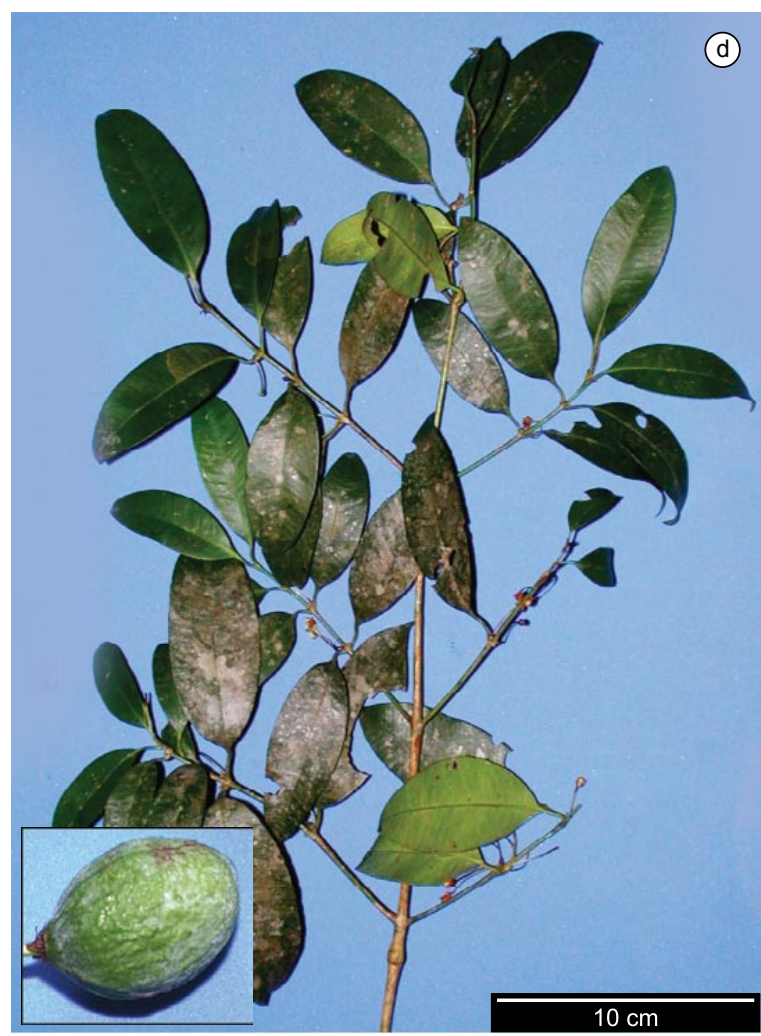

Figura 6. Chrysobalanaceae: a) Parinari excelsa (C. Urbanetz 241), em destaque detalhes da inflorescência e do fruto. Clusiaceae: b) Calophyllum brasiliense (C. Urbanetz 407), em destaque detalhe da inflorescência; c) Clusia criuva (C. Urbanetz 295), em destaque detalhe da flor; d) Garcinia gardneriana (C. Urbanetz 300), em destaque detalhe do fruto.

Figure 6. Chrysobalanaceae: a) Parinari excelsa (C. Urbanetz 241), inflorescence and fruit. Clusiaceae: b) Calophyllum brasiliense (C. Urbanetz 407), inflorescence in detail; c) Clusia criuva (C. Urbanetz 295), flower in detail; d) Garcinia gardneriana (C. Urbanetz 300), fruit in detail. 
Urbanetz, C. et al.
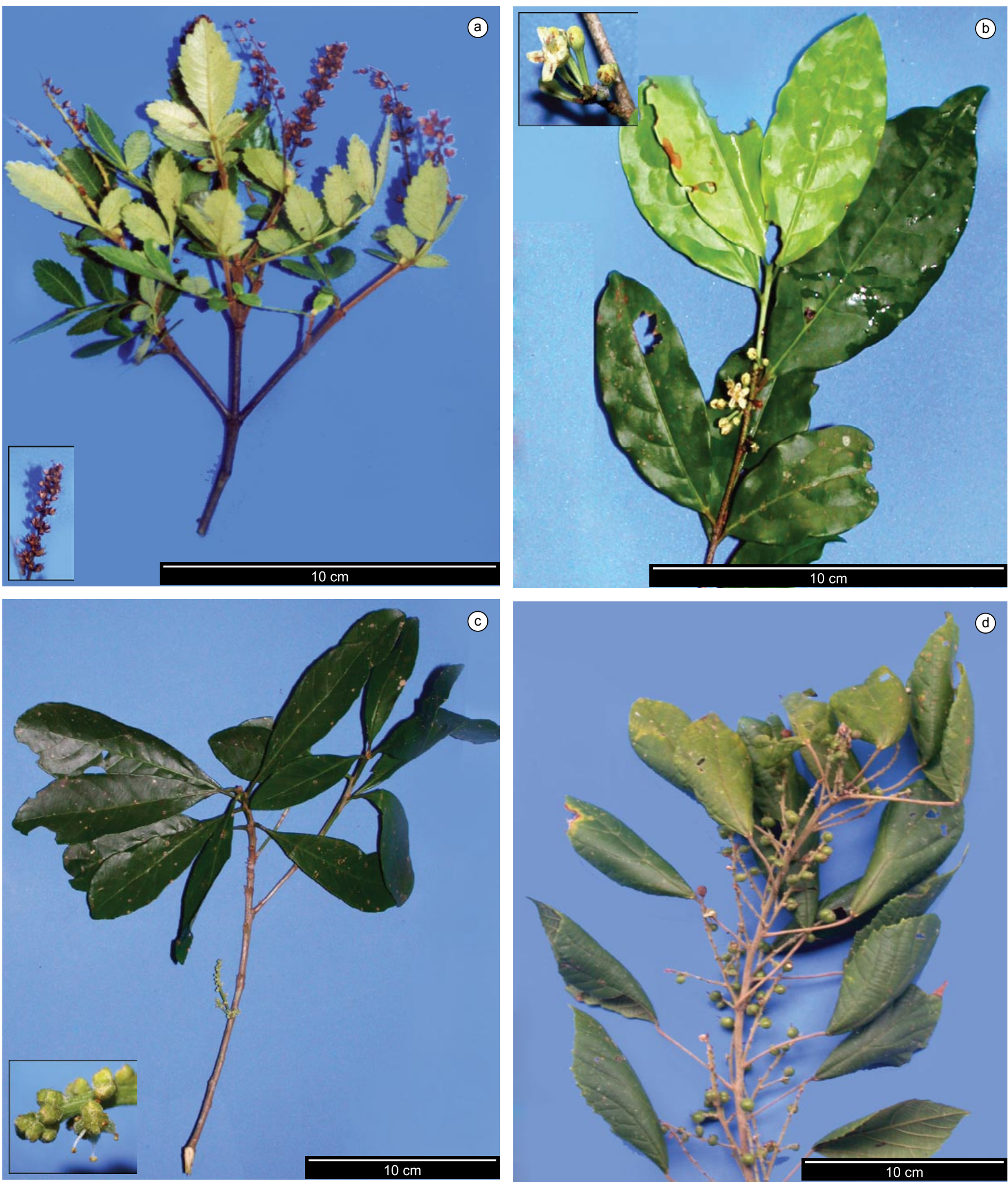

Figura 7. Cunnoniaceae: a) Weinmannia paullinifolia (C. Urbanetz 361), em destaque detalhe dos frutos. Erytrhoxylaceae: b) Erythroxylum cuspidifolium (C. Urbanetz 265), em destaque detalhe da flor. Euphorbiaceae: c) Actinostemon concolor (C. Urbanetz 359); em destaque detalhe da inflorescência; d) Alchornea glandulosa (C. Urbanetz 90).

Figure 7. Cunnoniaceae: a) Weinmannia paullinifolia (C. Urbanetz 361), fruits in detail. Erytrhoxylaceae: b) Erythroxylum cuspidifolium (C. Urbanetz 265), flower in detail. Euphorbiaceae: c) Actinostemon concolor (C. Urbanetz 359); inflorescence in detail; d) Alchornea glandulosa (C. Urbanetz 90). 
Chave de identificação de espécies lenhosas
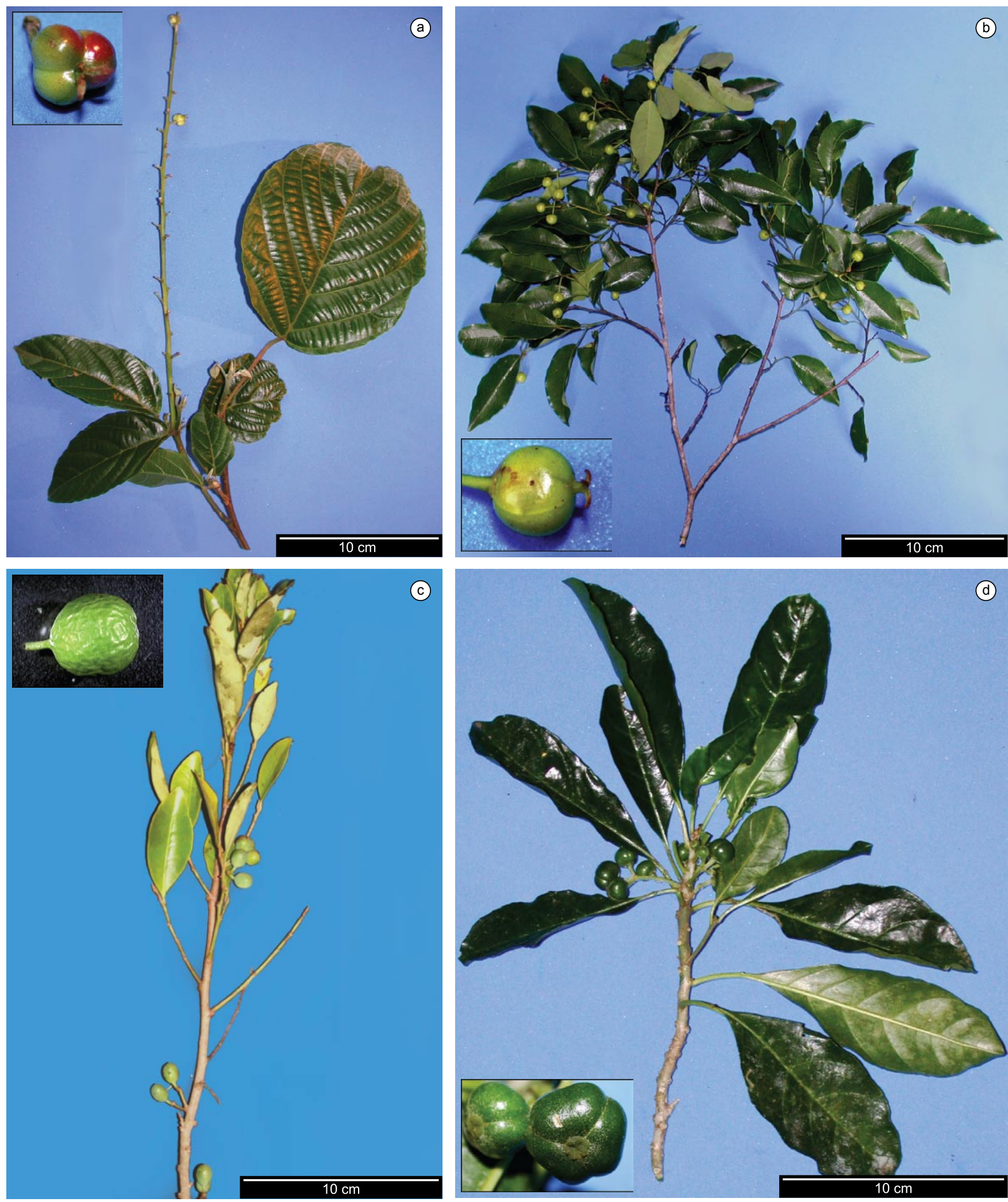

Figura 8. Euphorbiaceae: a) Aparisthmium cordatum (C. Urbanetz 318), em destaque detalhe do fruto; b) Maprounea guianensis (C. Urbanetz 332), em destaque detalhe do fruto; c) Pera glabrata (C. Urbanetz 72), em destaque detalhe do fruto; d) Tetrorchidium rubrivenium (C. Urbanetz 236), em destaque detalhe dos frutos.

Figure 8. Euphorbiaceae: a) Aparisthmium cordatum (C. Urbanetz 318), fruit in detail; b) Maprounea guianensis (C. Urbanetz 332), fruit in detail; c) Pera glabrata (C. Urbanetz 72), fruit in detail; d) Tetrorchidium rubrivenium (C. Urbanetz 236), fruits in detail. 

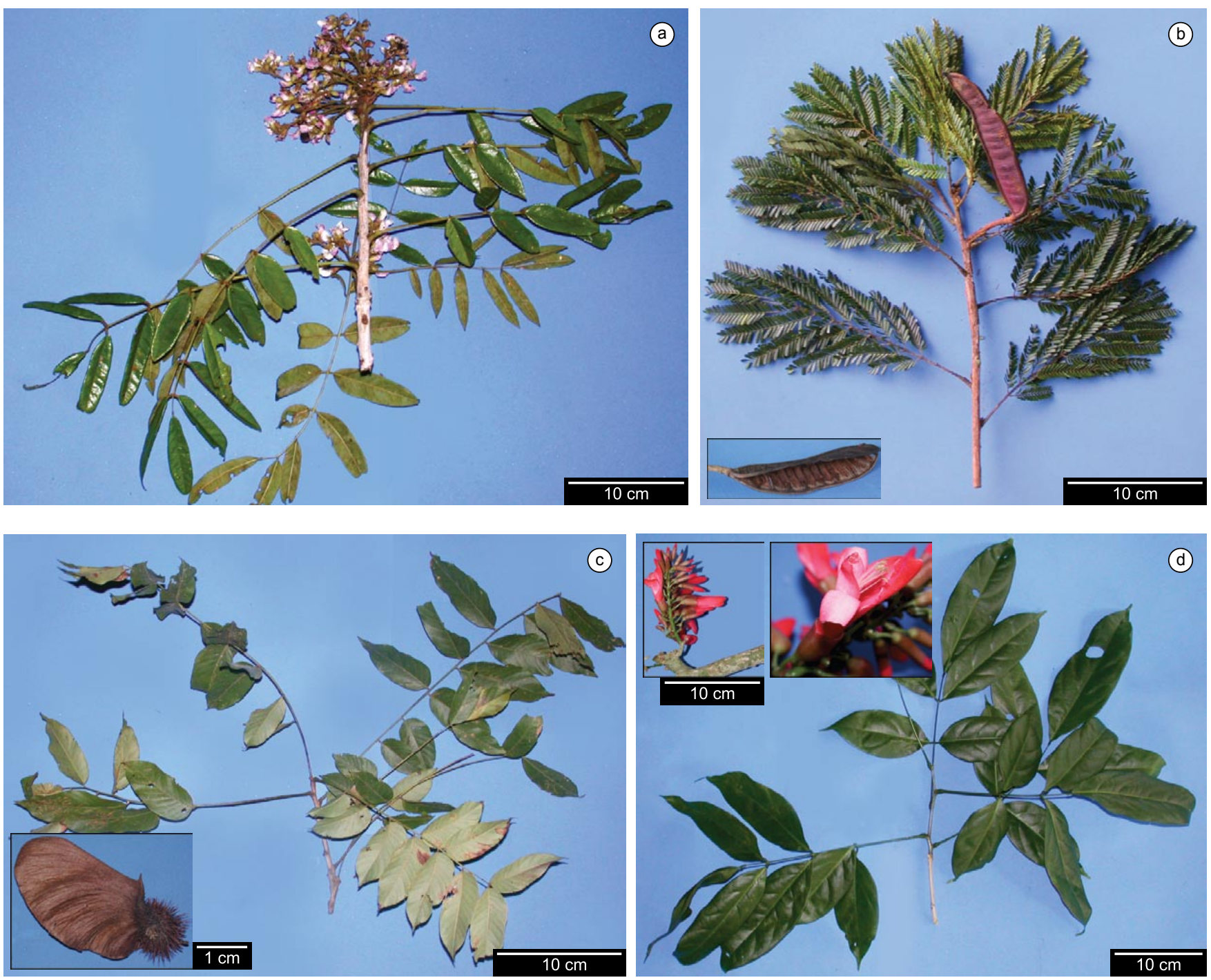

Figura 9. Fabaceae: a) Andira fraxinifolia (C. Urbanetz 225); b) Balizia pedicellaris (C. Urbanetz 57), em destaque detalhe do fruto; c) Centrolobium tomentosum (C. Urbanetz 35), em destaque detalhe do fruto; d) Dahlstedtia pinnata (C. Urbanetz 222), em destaque detalhes da inflorescência e da flor.

Figure 9. Fabaceae: a) Andira fraxinifolia (C. Urbanetz 225); b) Balizia pedicellaris (C. Urbanetz 57), fruit in detail; c) Centrolobium tomentosum (C. Urbanetz 35), fruit in detail; d) Dahlstedtia pinnata (C. Urbanetz 222), inflorescence and flower in detail. 
Chave de identificação de espécies lenhosas
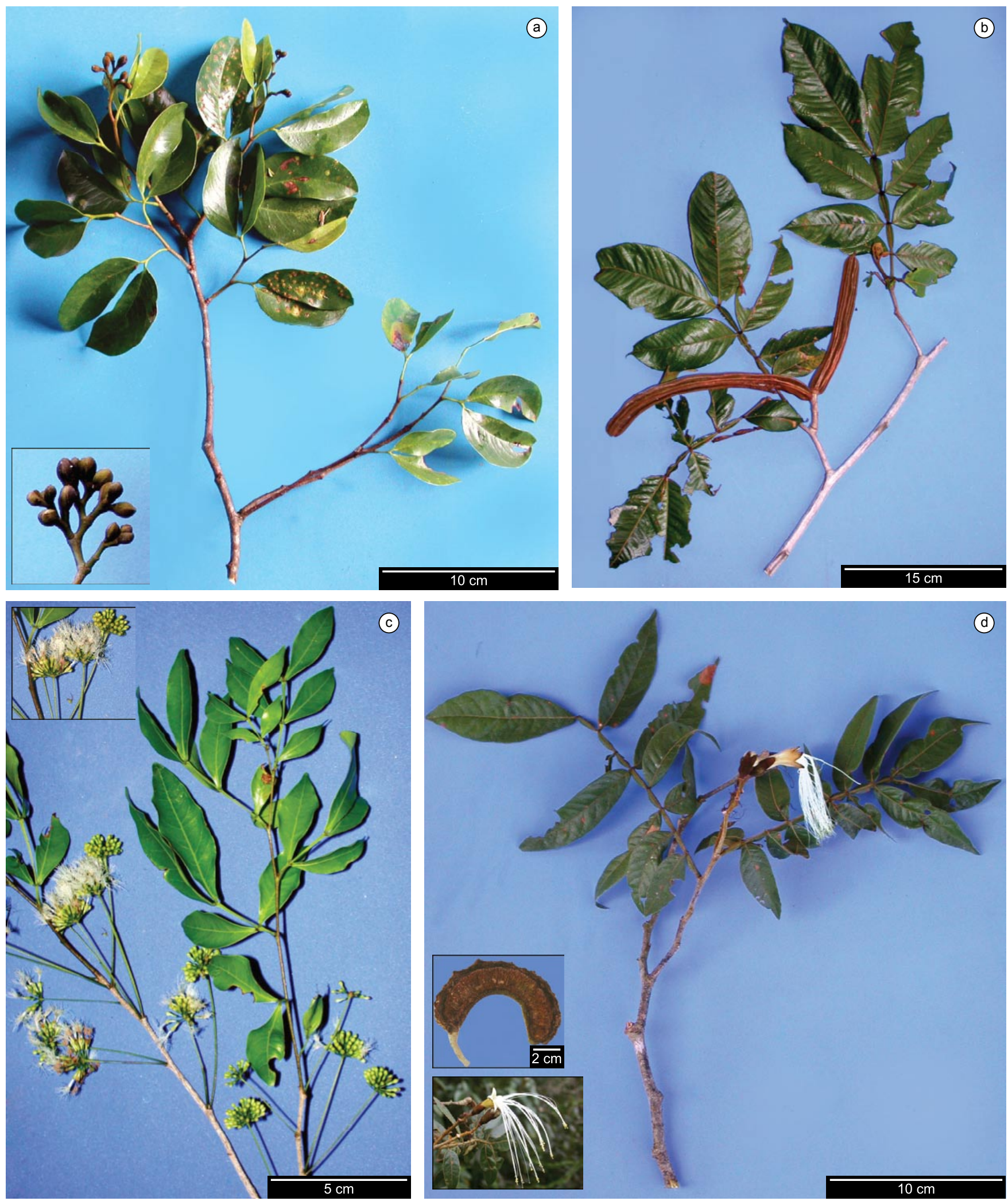

Figura 10. Fabaceae: a) Hymenaea courbaril, em destaque detalhe dos botões na inflorescência (C. Urbanetz 290); b) Inga edulis (C. Urbanetz 92); c) Inga lanceifolia (C. Urbanetz 267), em destaque detalhe da inflorescência; d) Inga sessilis (C. Urbanetz 96), em destaque detalhes da flor e do fruto.

Figure 10. Fabaceae: a) Hymenaea courbaril, buds in the inflorescence in detail (C. Urbanetz 290); b) Inga edulis (C. Urbanetz 92); c) Inga lanceifolia (C. Urbanetz 267), inflorescence in detail; d) Inga sessilis (C. Urbanetz 96), flower and fruit in detail. 

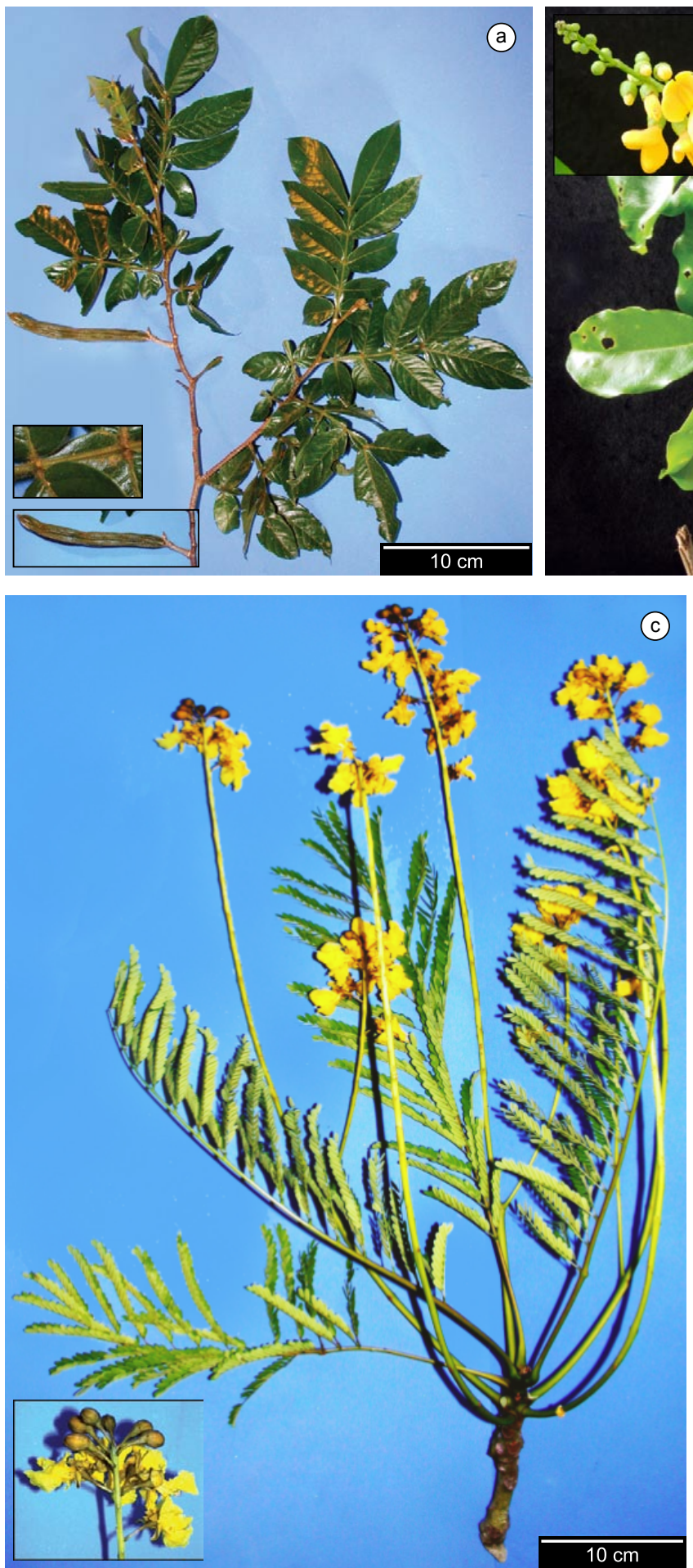
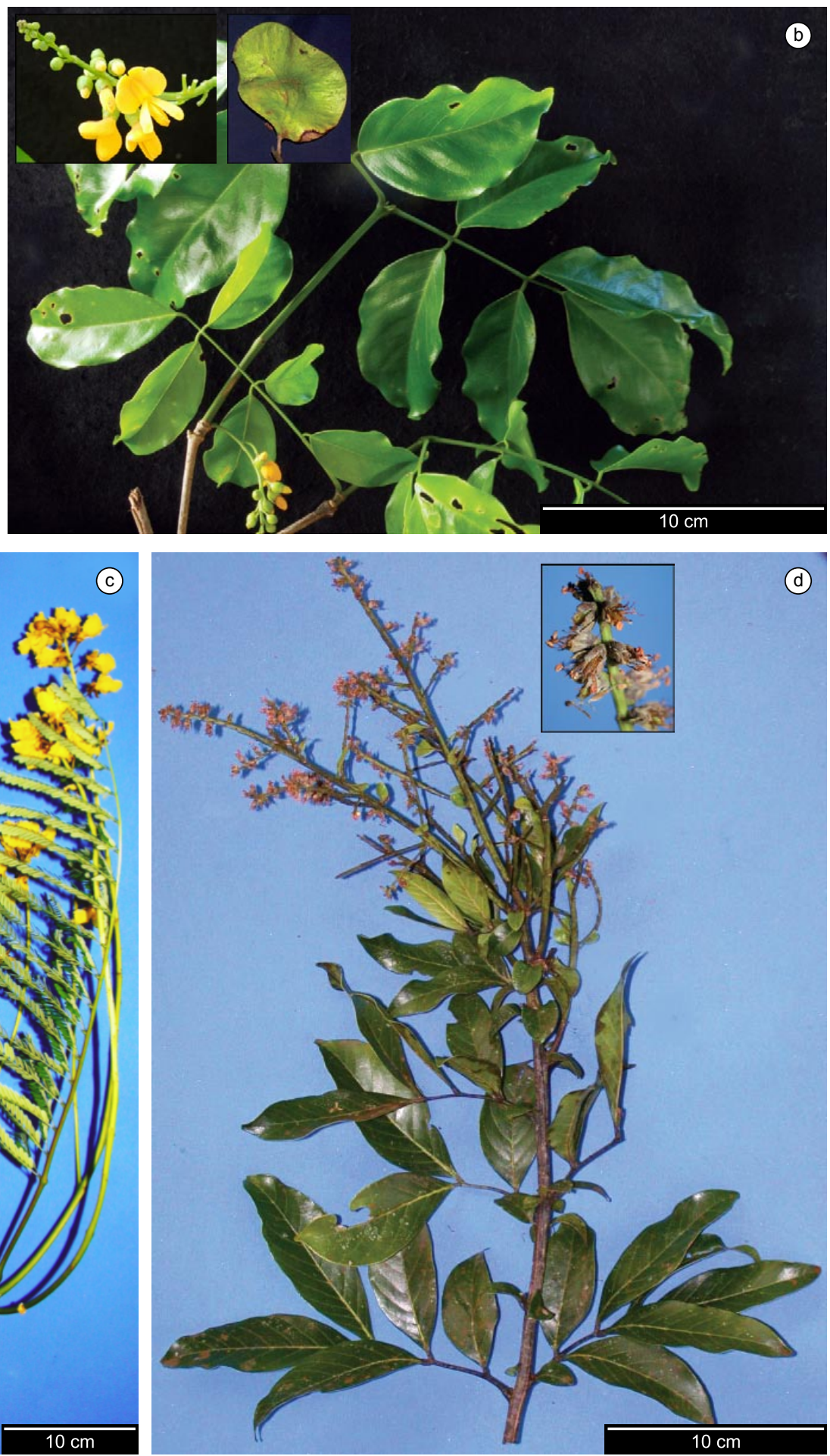

Figura 11. Fabaceae: a) Inga vera (C. Urbanetz 323), em destaque detalhes do fruto e do nectário entre os folíolos; b) Pterocarpus rohrii (C. Urbanetz 180), em destaque detalhes do fruto e da inflorescência. (C. Urbanetz 180); c) Schizolobium parahyba (C. Urbanetz 248), em destaque detalhe da inflorescência; d) Sclerolobium denudatum (C. Urbanetz 158), em destaque detalhe da inflorescência.

Figure 11. Fabaceae: a) Inga vera (C. Urbanetz 323), fruit and nectary between the leaflets in detail; b) Pterocarpus rohrii (C. Urbanetz 180), fruit and inflorescence in detail. (C. Urbanetz 180); c) Schizolobium parahyba (C. Urbanetz 248), inflorescence in detail; d) Sclerolobium denudatum (C. Urbanetz 158), inflorescence in detail. 

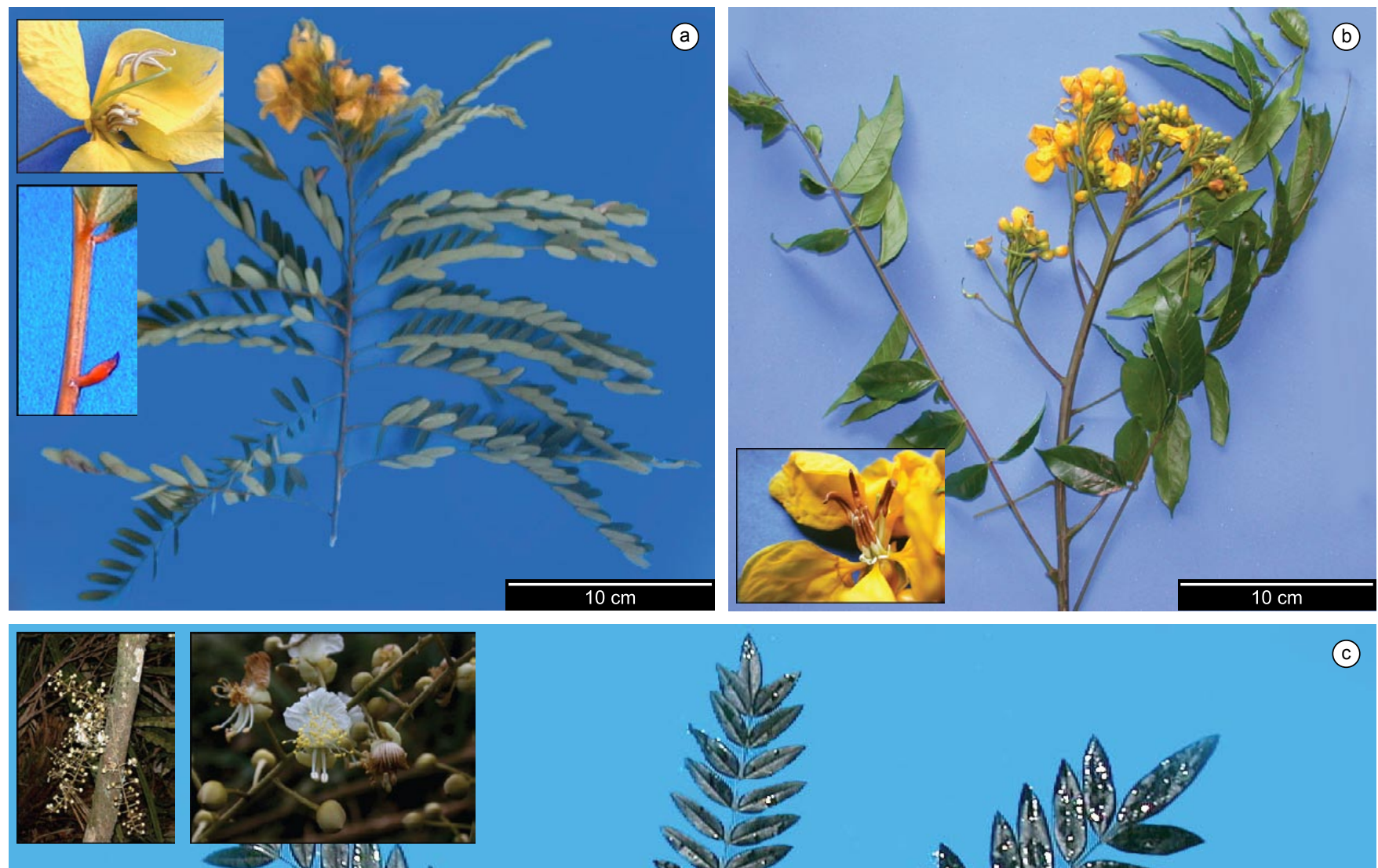

(c)

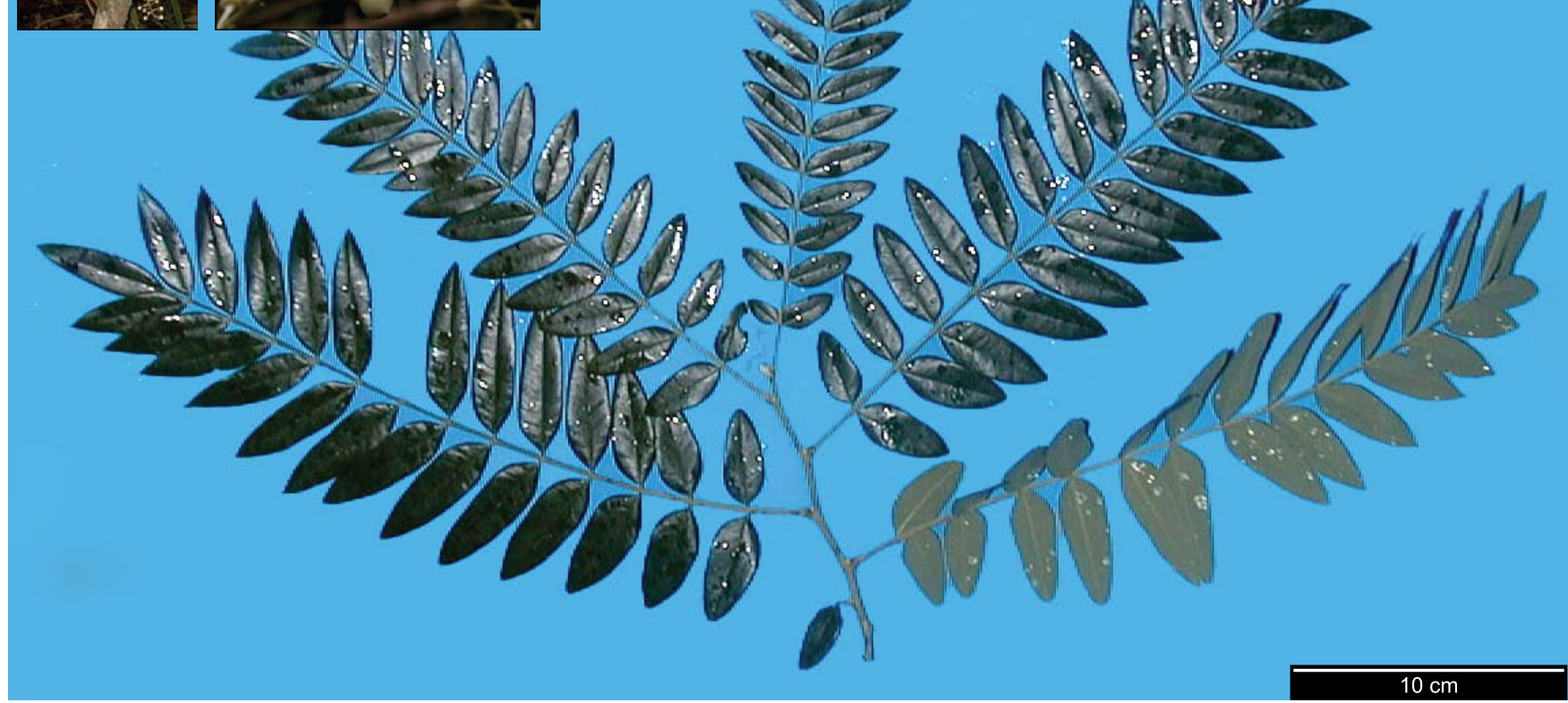

Figura 12. Fabaceae: a) Senna multijuga (C. Urbanetz 362), em destaque detalhes da flor e do nectário extra-floral no pecíolo; b) Senna silvestris. (C. Urbanetz 294), em destaque detalhe da flor; c) Swartzia submarginata (C. Urbanetz 10), em destaque detalhes das inflorescências no tronco e da flor.

Figure 12. Fabaceae: a) Senna multijuga (C. Urbanetz 362), flower and extrafloral nectary on the petiole; b) Senna silvestris. (C. Urbanetz 294), flower in detail; c) Swartzia submarginata (C. Urbanetz 10), inflorescence on the trunk and flower in detail. 
Urbanetz, C. et al.
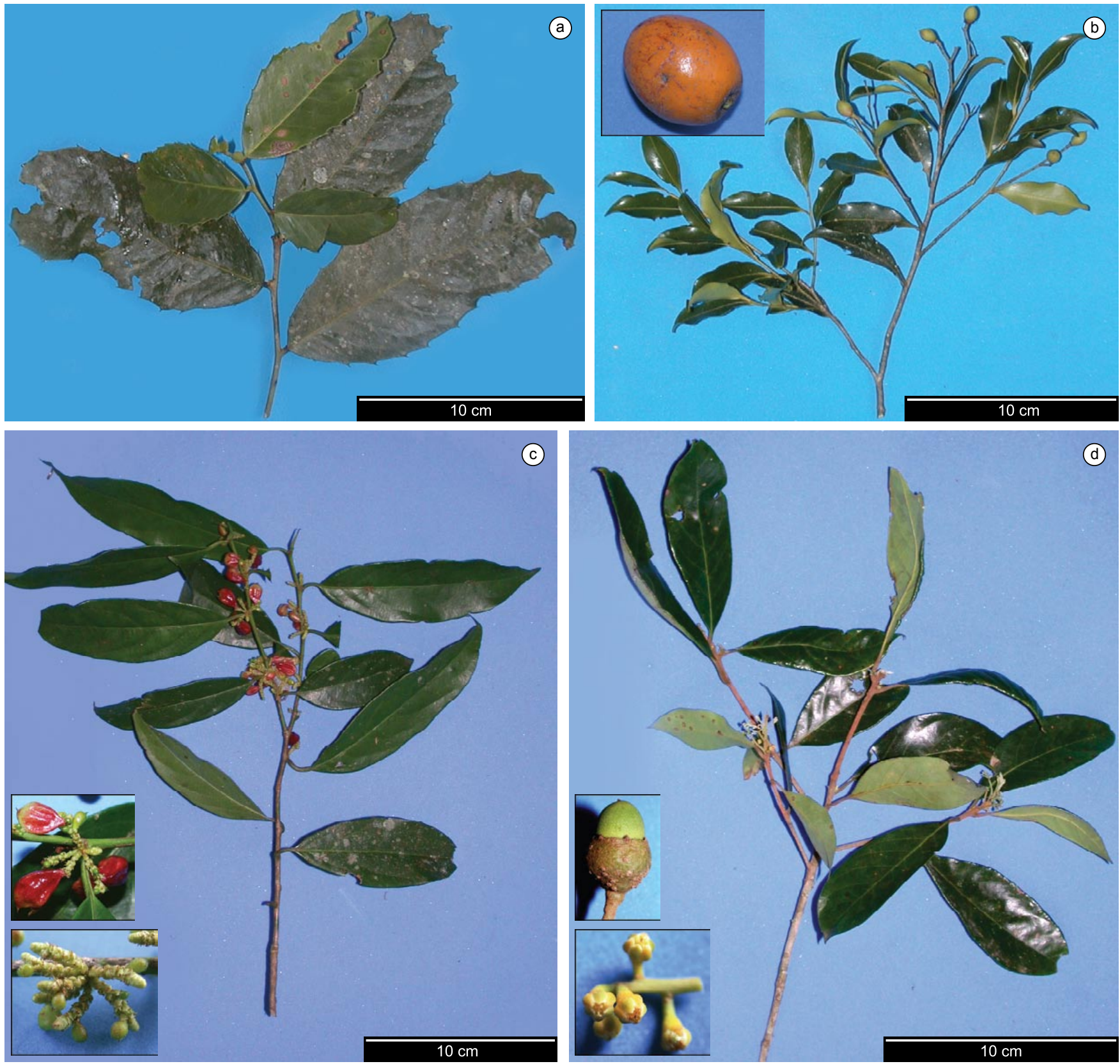

Figura 13. Fabaceae: a) Zollernia ilicifolia (C. Urbanetz 409). Humiriaceae: b) Vantanea compacta (C. Urbanetz 190), em destaque detalhe do fruto. Lacistemaceae: c) Lacistema lucidum (C. Urbanetz 110), em destaque detalhes da inflorescência e dos frutos. Lauraceae: d) Aniba firmula (C. Urbanetz 291), em destaque detalhes da inflorescência e do fruto.

Figure 13. Fabaceae: a) Zollernia ilicifolia (C. Urbanetz 409). Humiriaceae: b) Vantanea compacta (C. Urbanetz 190), fruit in detail. Lacistemaceae: c) Lacistema lucidum (C. Urbanetz 110), inflorescence and fruits in detail. Lauraceae: d) Aniba firmula (C. Urbanetz 291), inflorescence and fruit in detail. 

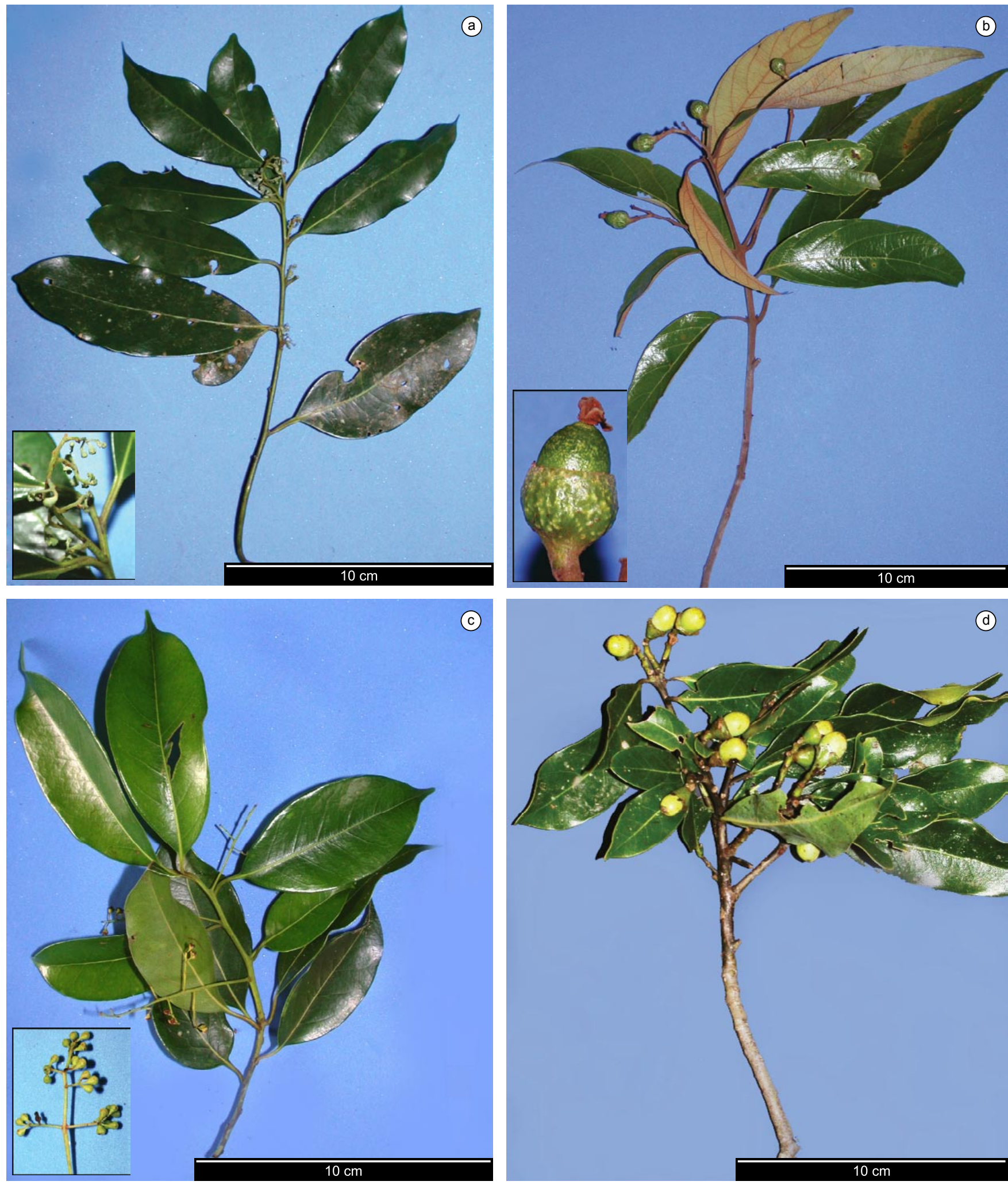

Figura 14. Lauraceae: a) Cryptocarya saligna (C. Urbanetz 217), em destaque detalhe da inflorescência; b) Nectandra oppositifolia (C. Urbanetz 48), em destaque detalhe do fruto; c) Ocotea diospyrifolia (C. Urbanetz 327), em destaque detalhe da inflorescência; d) Ocotea silvestris (C. Urbanetz 40).

Figure 14. Lauraceae: a) Cryptocarya saligna (C. Urbanetz 217), inflorescence in detail; b) Nectandra oppositifolia (C. Urbanetz 48), fruit in detail; c) Ocotea diospyrifolia (C. Urbanetz 327), inflorescence in detail; d) Ocotea silvestris (C. Urbanetz 40). 
Urbanetz, C. et al.

Famílias Malpighiaceae e Melastomataceae
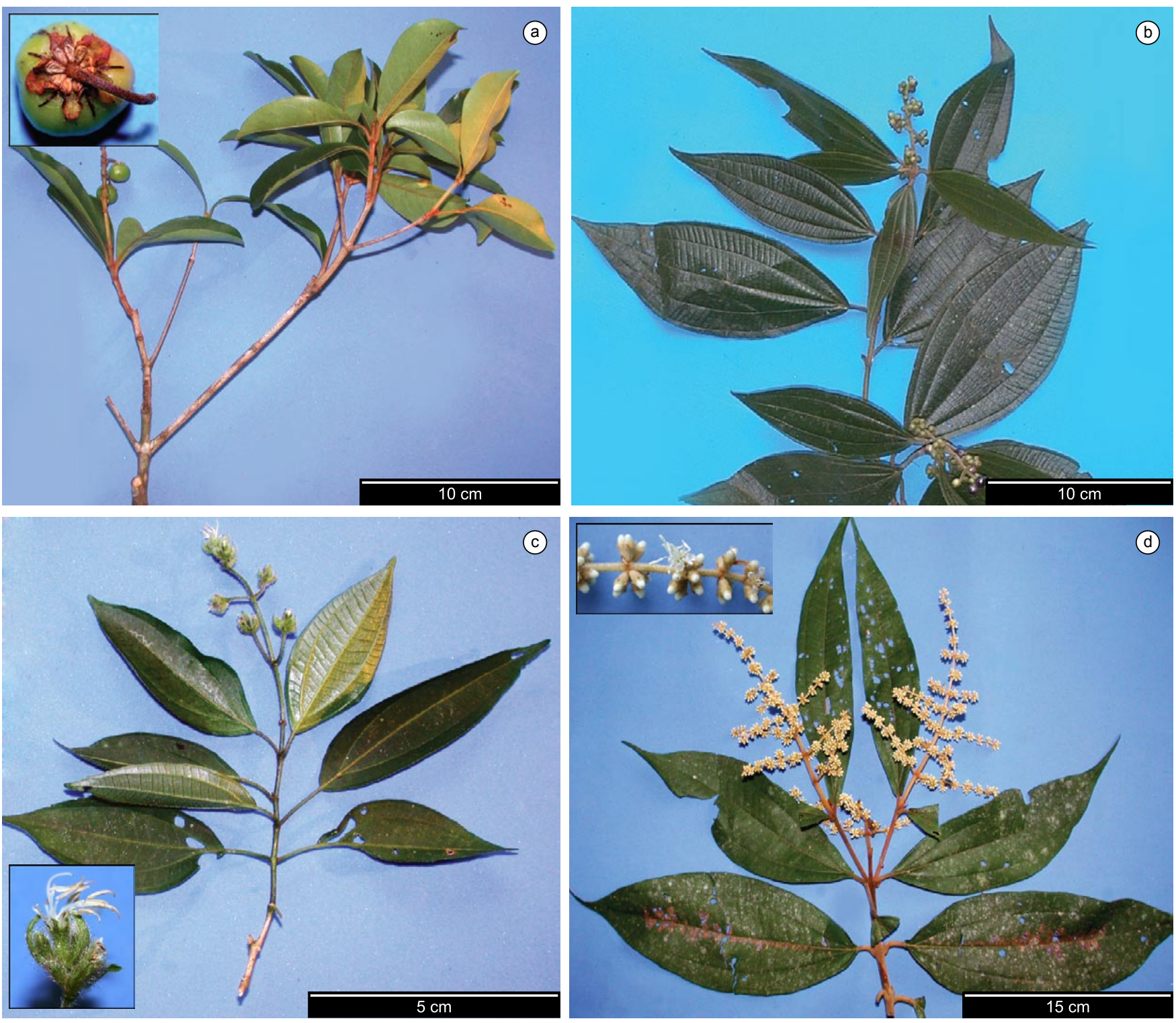

Figura 15. Malpighiaceae: a) Byrsonima ligustrifolia (C. Urbanetz 316), em destaque detalhe do fruto. Melastomataceae: b) Leandra cf. dasytricha (C. Urbanetz 376); c) Leandra cf. dubia (C. Urbanetz 317), em destaque detalhe da flor; d) Leandra scabra (C. Urbanetz 284), em destaque detalhe da inflorescência.

Figure 15. Malpighiaceae: a) Byrsonima ligustrifolia (C. Urbanetz 316), fruit in detail. Melastomataceae: b) Leandra cf. dasytricha (C. Urbanetz 376); c) Leandra cf. dubia (C. Urbanetz 317), flower in detail; d) Leandra scabra (C. Urbanetz 284), inflorescence in detail. 

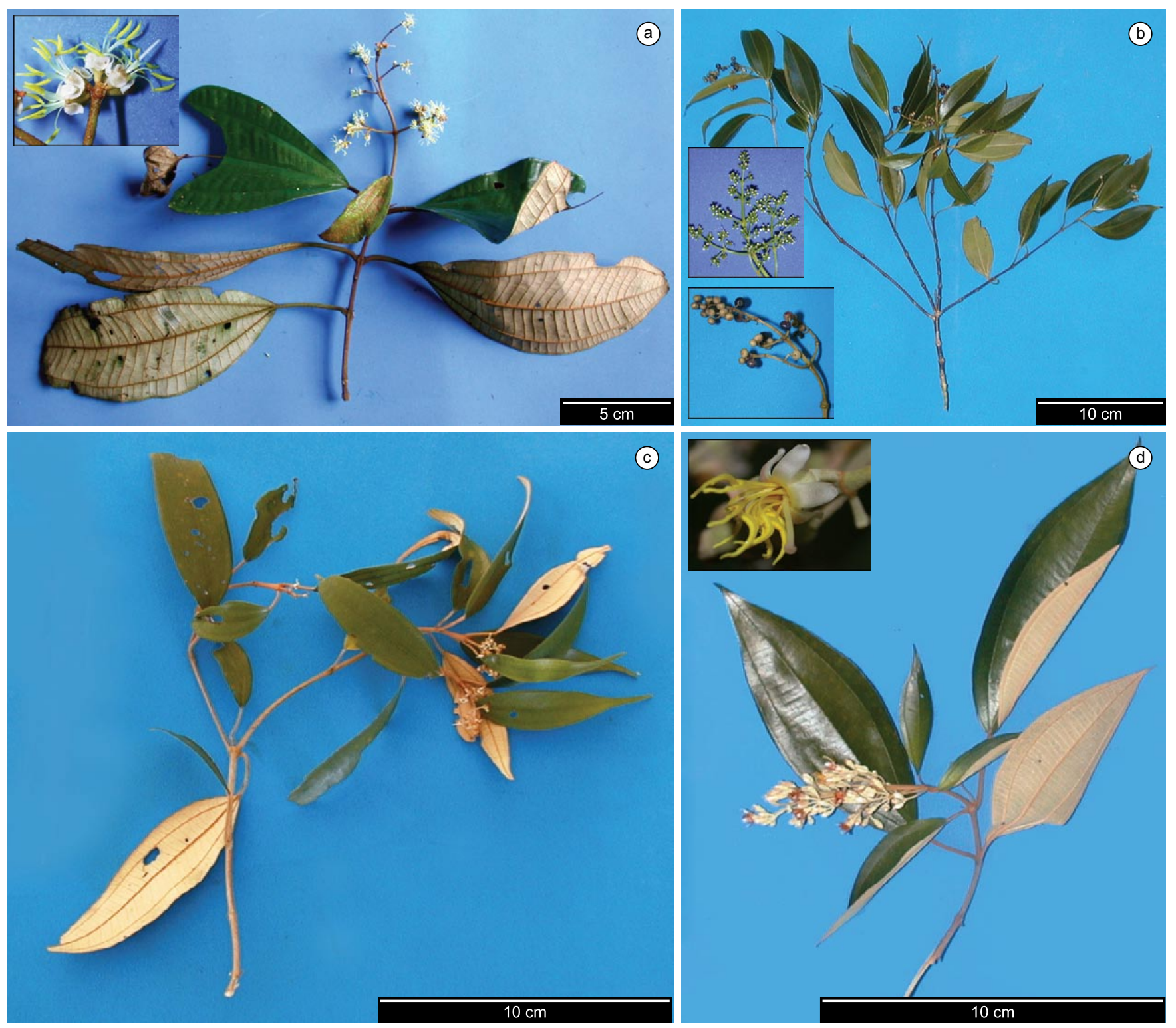

Figura 16. Melastomataceae: a) Miconia cinerascens (C. Urbanetz 293), em destaque detalhe da inflorescência; b) Miconia cinnamomifolia (C. Urbanetz 268), em destaque detalhes da inflorescência e dos frutos; c) Miconia cubatanensis (C. Urbanetz 397); d) Miconia dodecandra (C. Urbanetz 31), em destaque detalhe da flor.

Figure 16. Melastomataceae: a) Miconia cinerascens (C. Urbanetz 293), inflorescence in detail; b) Miconia cinnamomifolia (C. Urbanetz 268), inflorescence and fruits in detail; c) Miconia cubatanensis (C. Urbanetz 397); d) Miconia dodecandra (C. Urbanetz 31), flower in detail. 
Urbanetz, C. et al.

Familia Melastomataceae
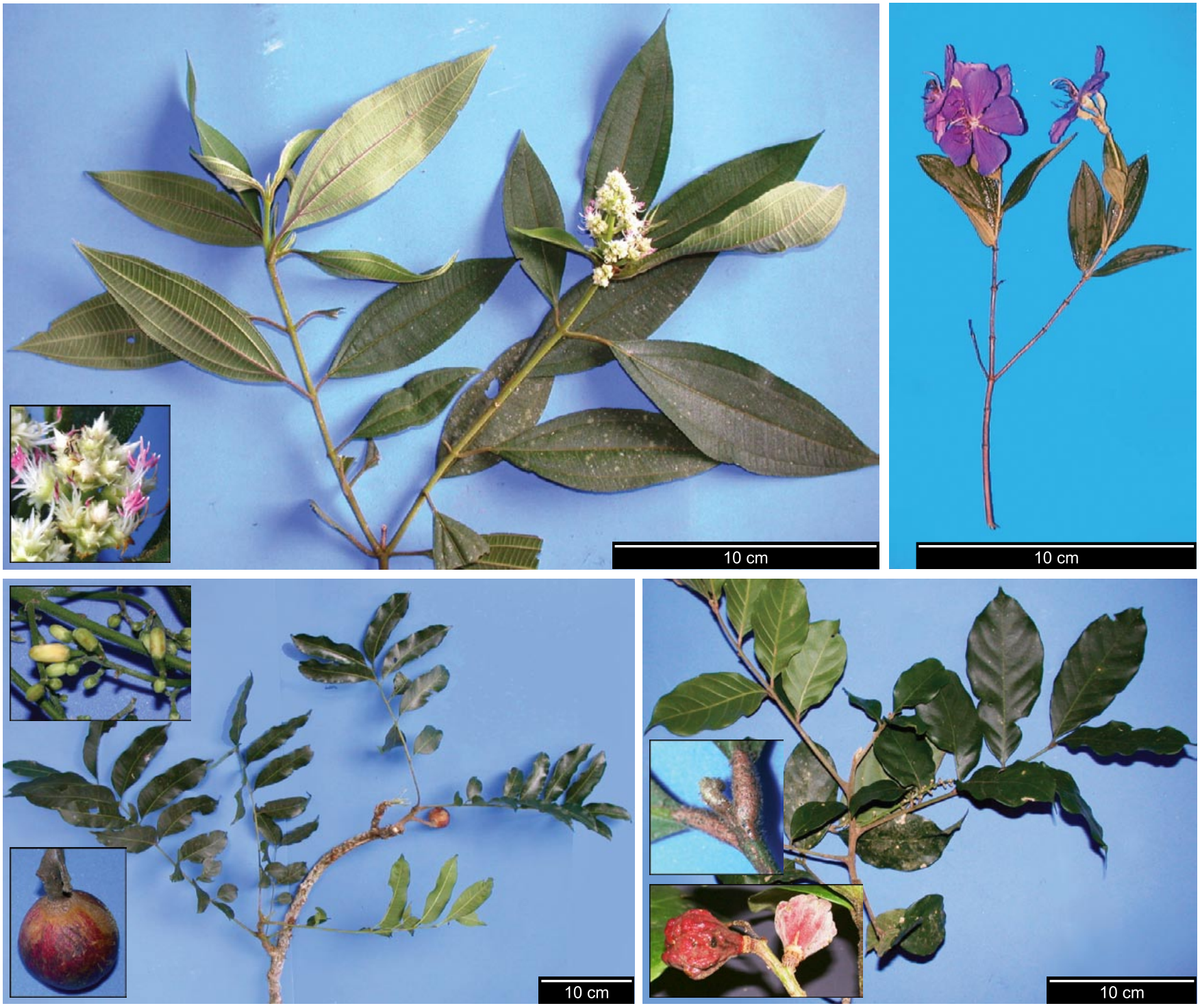

Figura 17. Melastomataceae: a) Miconia saldanhaei (C. Urbanetz 276), em destaque detalhe da inflorescência; b) Tibouchina weddelli (C. Urbanetz 403). Meliaceae: c) Cabralea canjerana (C. Urbanetz 162), em destaque detalhes da inflorescência e do fruto; d) Guarea macrophylla (C. Urbanetz 274), em destaque detalhes dos frutos e da parte terminal da folha.

Figure 17. Melastomataceae: a) Miconia saldanhaei (C. Urbanetz 276), inflorescence in detail; b) Tibouchina weddelli (C. Urbanetz 403). Meliaceae: c) Cabralea canjerana (C. Urbanetz 162), inflorescence and fruit in detail; d) Guarea macrophylla (C. Urbanetz 274), fruits and distal portion of the leave in detail. 

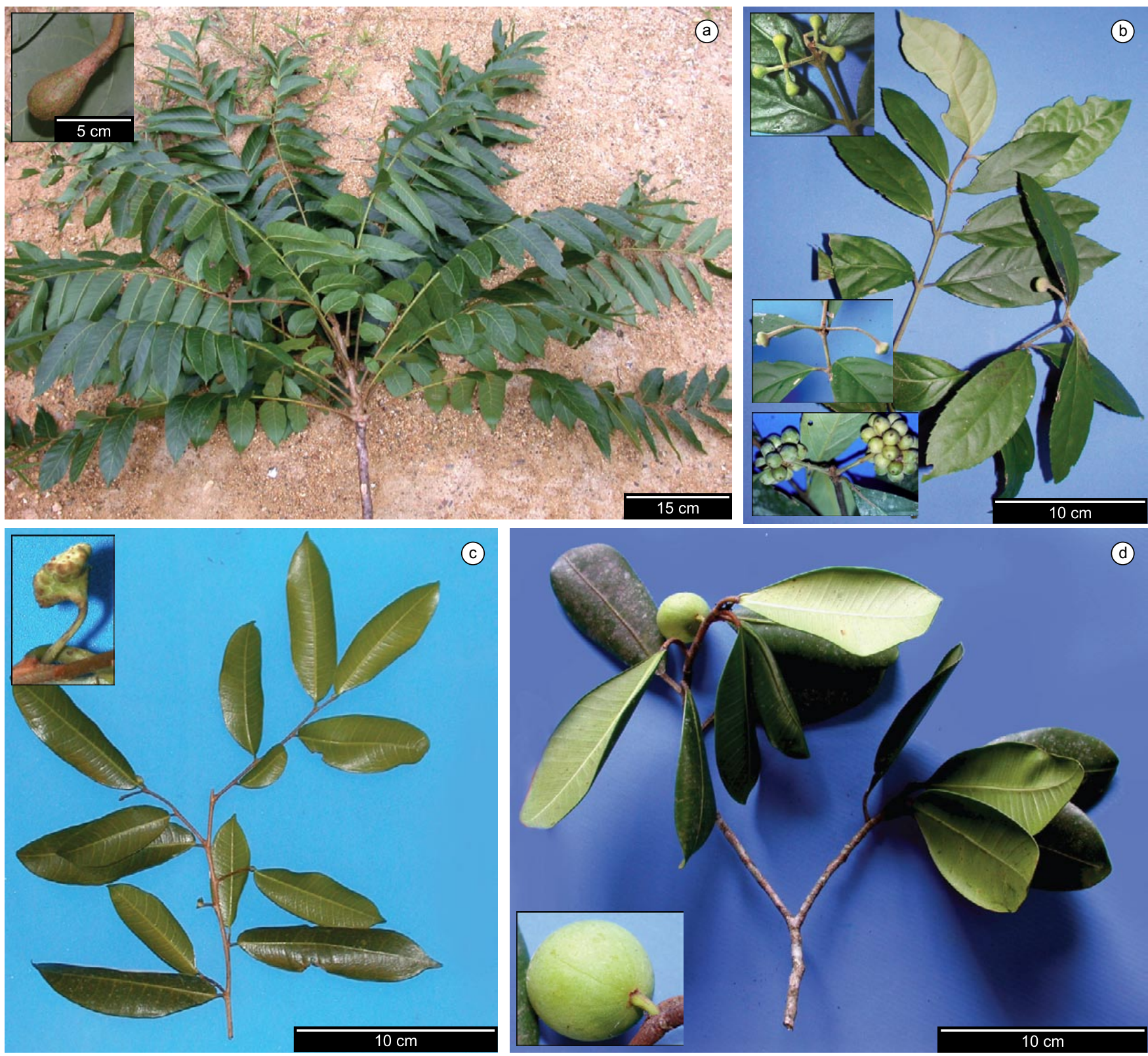

Figura 18. Meliaceae: a) Cedrela fissilis (C. Urbanetz 320), em destaque detalhe do fruto imaturo. Monimiaceae: b) Mollinedia schottiana (C. Urbanetz 278), em destaque detalhes das flores e dos frutos. Moraceae: c) Brosimum glaziovii (C. Urbanetz 379), em destaque detalhe da flor; d) Ficus pulchella (C. Urbanetz 365), em destaque detalhe do fruto.

Figure 18. Meliaceae: a) Cedrela fissilis (C. Urbanetz 320), immature fruit in detail. Monimiaceae: b) Mollinedia schottiana (C. Urbanetz 278), flowers and fruits in detail. Moraceae: c) Brosimum glaziovii (C. Urbanetz 379), flower in detail; d) Ficus pulchella (C. Urbanetz 365), fruit in detail. 

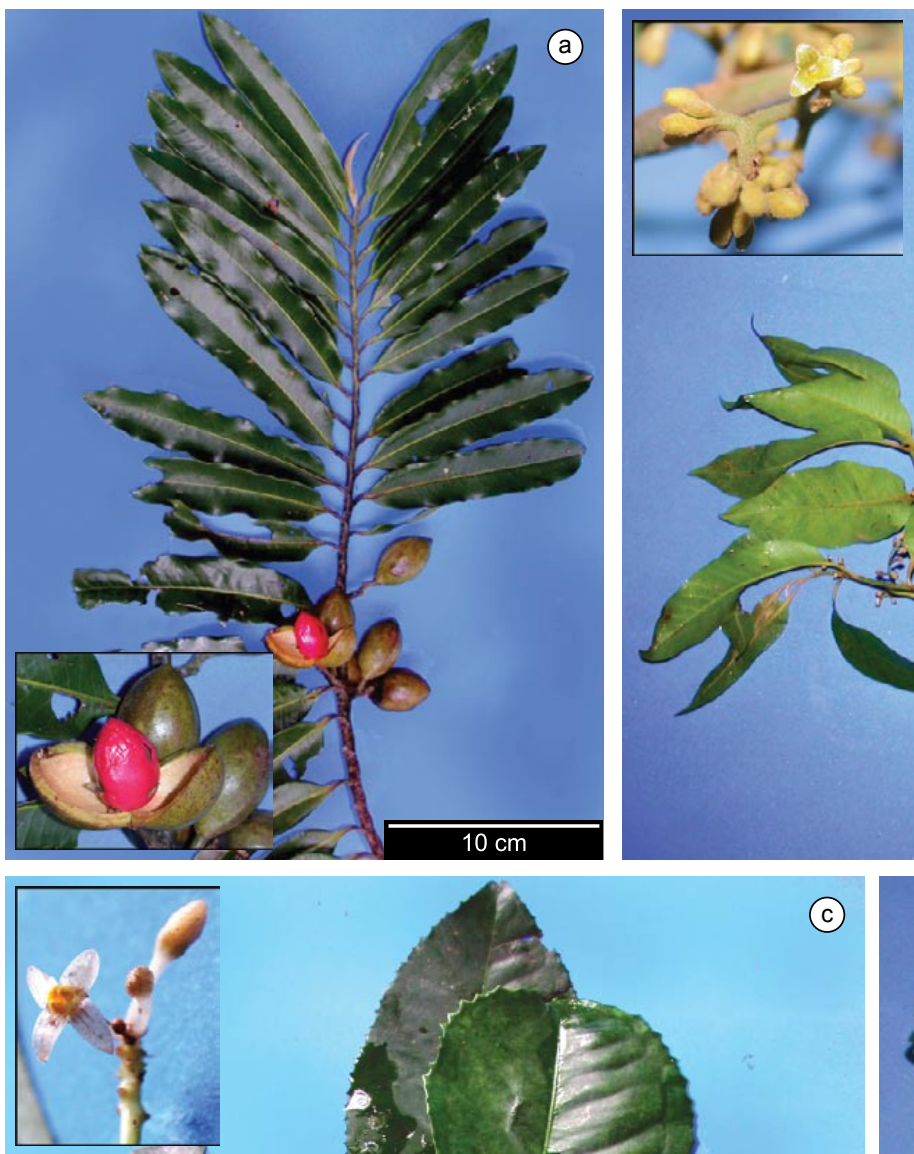

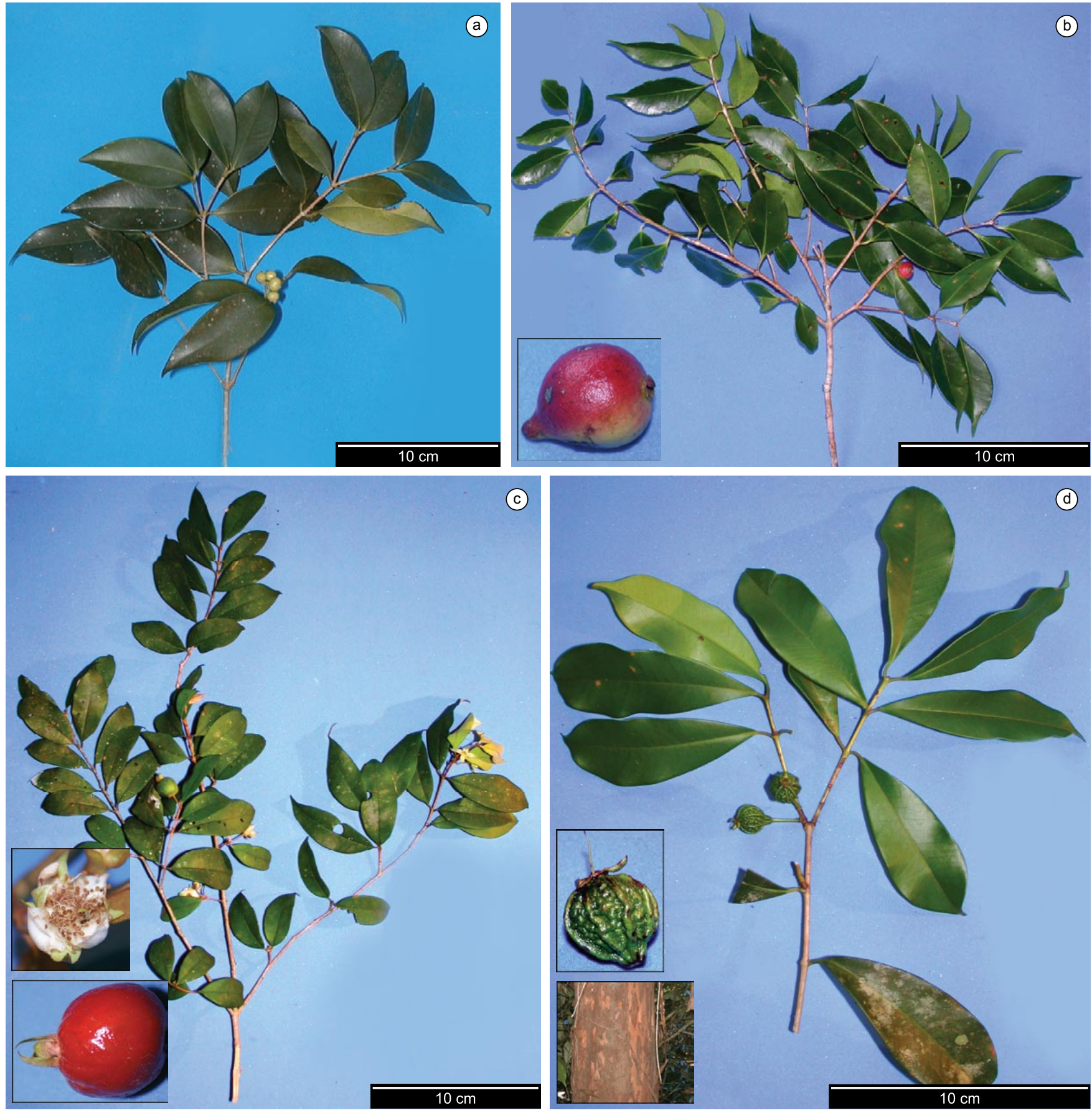

Figura 20. Myrtaceae: a) Calyptranthes strigipes (C. Urbanetz 396); b) Eugenia copacabanensis (C. Urbanetz 145), em destaque detalhe do fruto; c) Eugenia cuprea (C. Urbanetz 319), em destaque detalhes da flor e do fruto; d) Eugenia multicostata (C. Urbanetz 243), em destaque detalhes do tronco e do fruto.

Figure 20. Myrtaceae: a) Calyptranthes strigipes (C. Urbanetz 396); b) Eugenia copacabanensis (C. Urbanetz 145), fruit in detail; c) Eugenia cuprea (C. Urbanetz 319), flower and fruit in detail; d) Eugenia multicostata (C. Urbanetz 243), trunk and fruit in detail. 

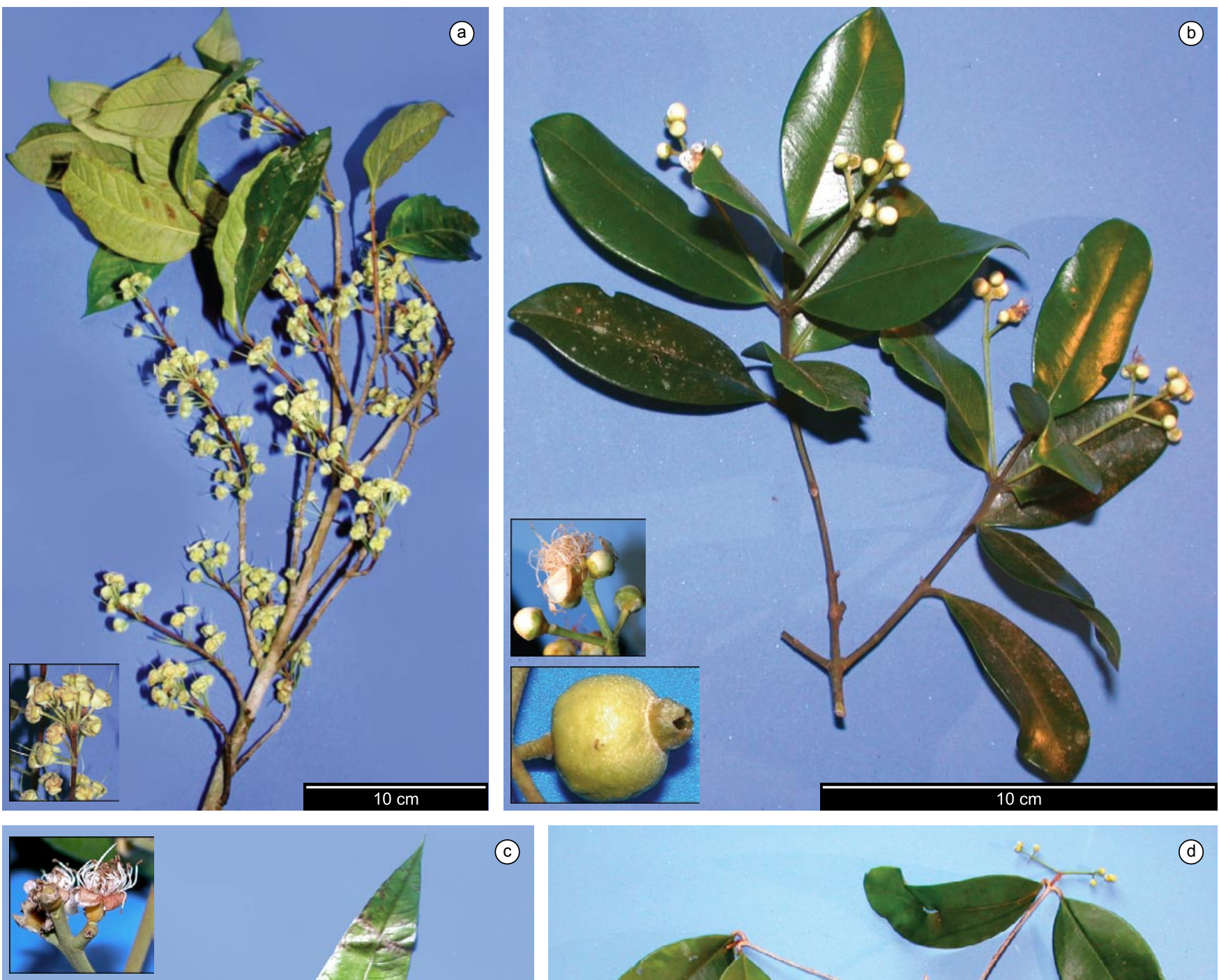

(C)

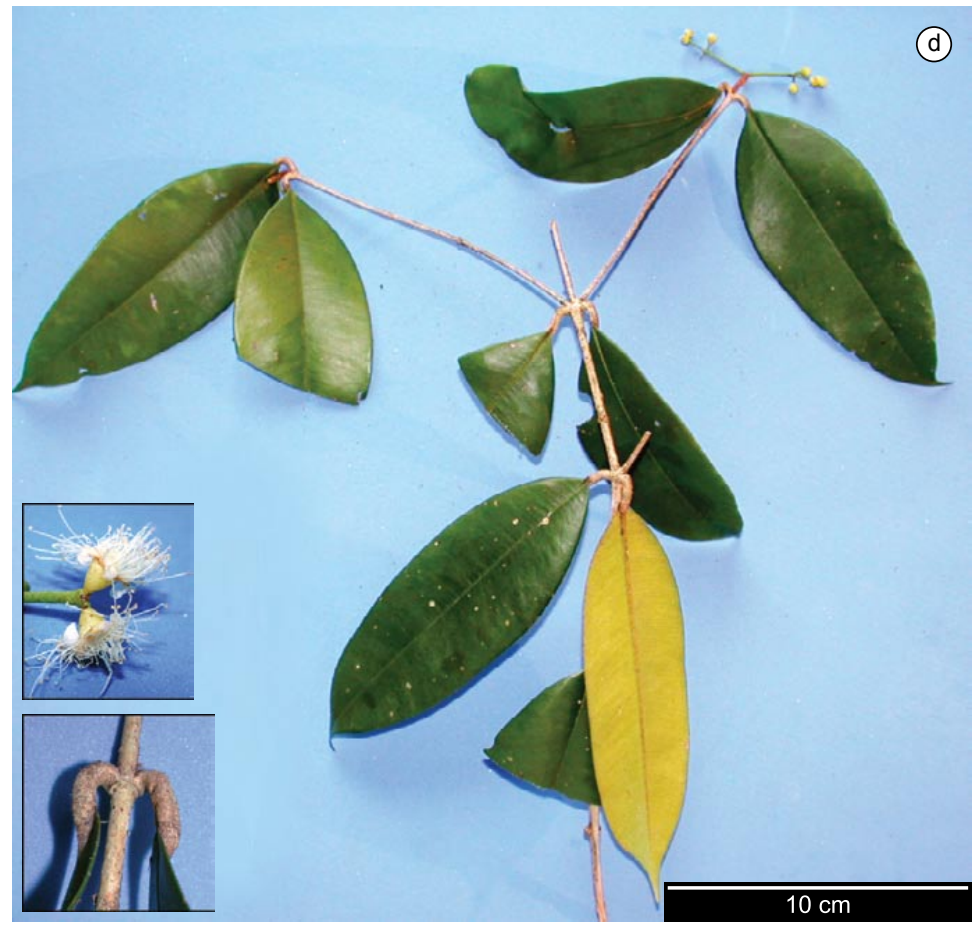

Figura 21. Myrtaceae: a) Eugenia mosenii (C. Urbanetz 410), em destaque detalhe das flores; b) Gomidesia schaueriana (C. Urbanetz 330), em destaque detalhes das flores e do fruto; c) Gomidesia spectabilis (C. Urbanetz 297), em destaque detalhe das flores; d) Marlierea eugeniopsoides (C. Urbanetz 324), em destaque detalhes das flores e do pecíolo.

Figure 21. Myrtaceae: a) Eugenia mosenii (C. Urbanetz 410), flowers in detail; b) Gomidesia schaueriana (C. Urbanetz 330), flowers and fruit in detail; c) Gomidesia spectabilis (C. Urbanetz 297), flowers in detail; d) Marlierea eugeniopsoides (C. Urbanetz 324), flowers and petiole in detail. 

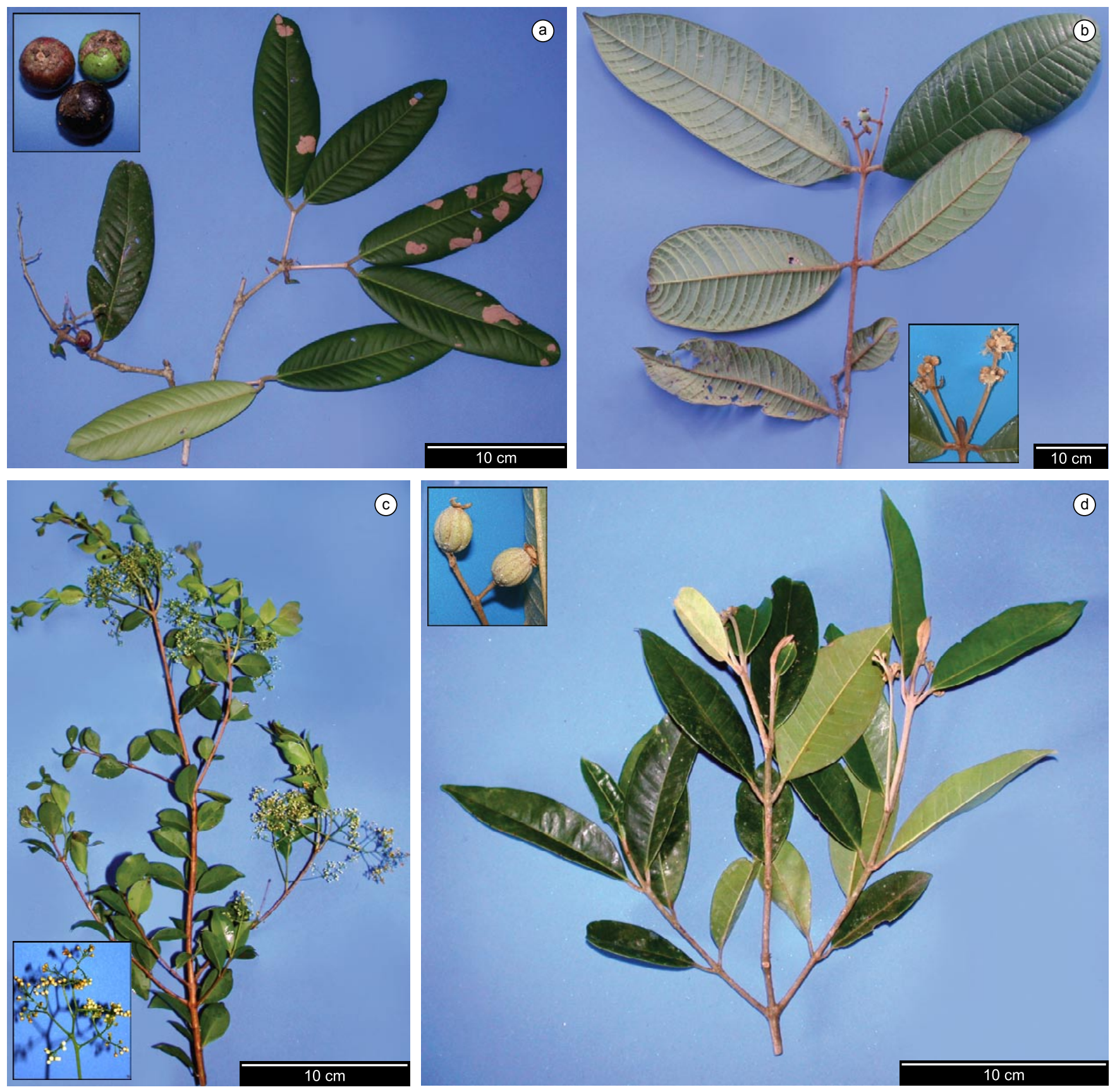

Figura 22. Myrtaceae: a) Marlierea tomentosa (C. Urbanetz 47), em destaque detalhe dos frutos; b) Myrcia aff. grandiflora (C. Urbanetz 36), em destaque detalhe da inflorescência; c) Myrcia multiflora (C. Urbanetz 254), em destaque detalhe da inflorescência; d) Myrcia pubipetala (C. Urbanetz 303), em destaque detalhe do fruto.

Figure 22. Myrtaceae: a) Marlierea tomentosa (C. Urbanetz 47), fruits in detail; b) Myrcia aff. grandiflora (C. Urbanetz 36), inflorescence in detail; c) Myrcia multiflora (C. Urbanetz 254), inflorescence in detail; d) Myrcia pubipetala (C. Urbanetz 303), fruit in detail. 

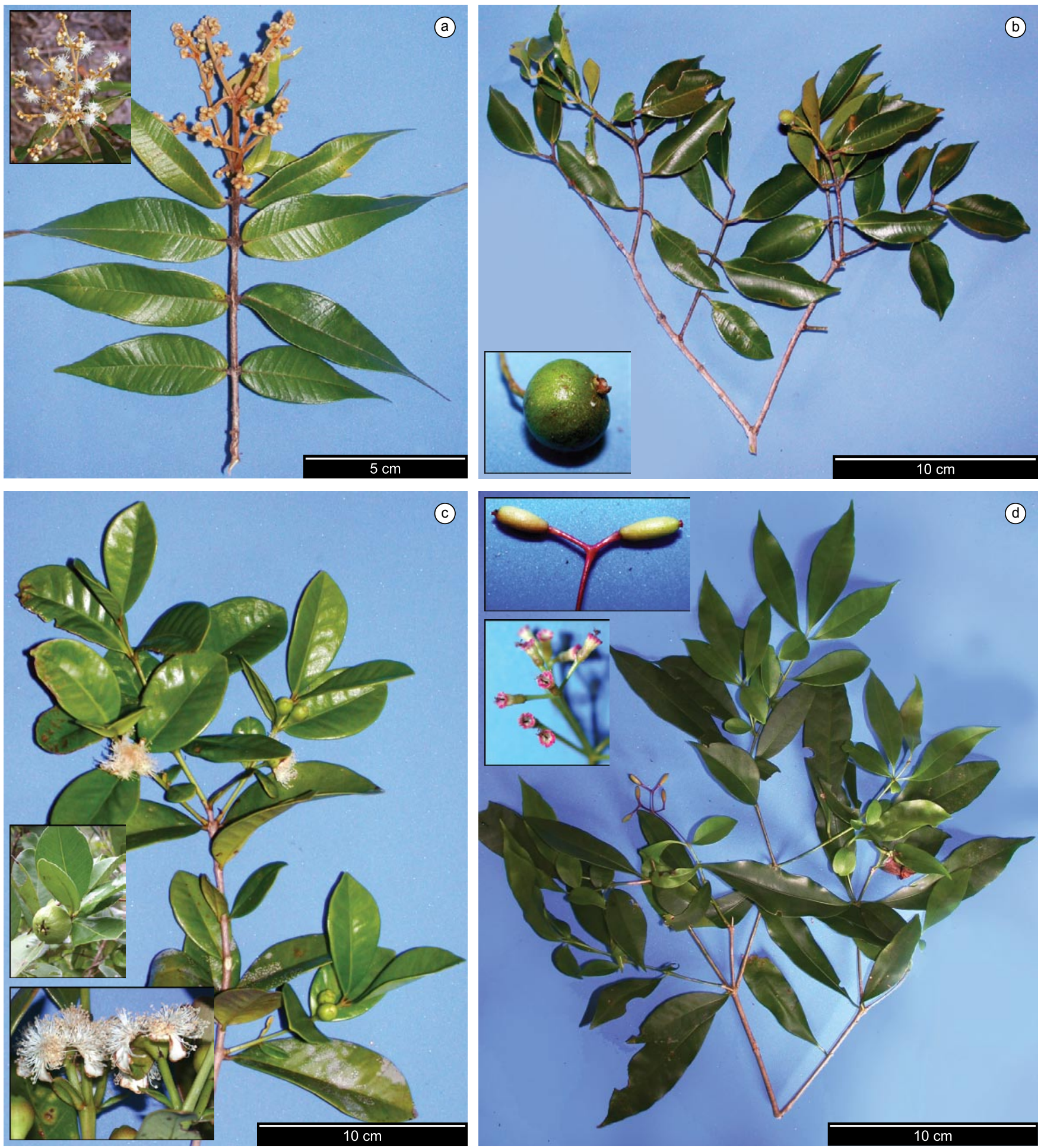

Figura 23. Myrtaceae: a) Myrcia splendens (C. Urbanetz 20), em destaque detalhe da inflorescência; b) Myrcia stictophylla (C. Urbanetz 303), em destaque detalhe do fruto; c) Psidium cattleianum (C. Urbanetz 223), em destaque detalhe das flores e do fruto. Nyctaginaceae: d) Guapira opposita (C. Urbanetz 227), em destaque detalhes da inflorescência e dos frutos.

Figure 23. Myrtaceae: a) Myrcia splendens (C. Urbanetz 20), inflorescence in detail; b) Myrcia stictophylla (C. Urbanetz 303), fruit in detail; c) Psidium cattleianum (C. Urbanetz 223), flowers and fruit in detail. Nyctaginaceae: d) Guapira opposita (C. Urbanetz 227), inflorescence and fruits in detail. 
Famílias Nyctaginaceae, Ochnaceae e Olacaceae
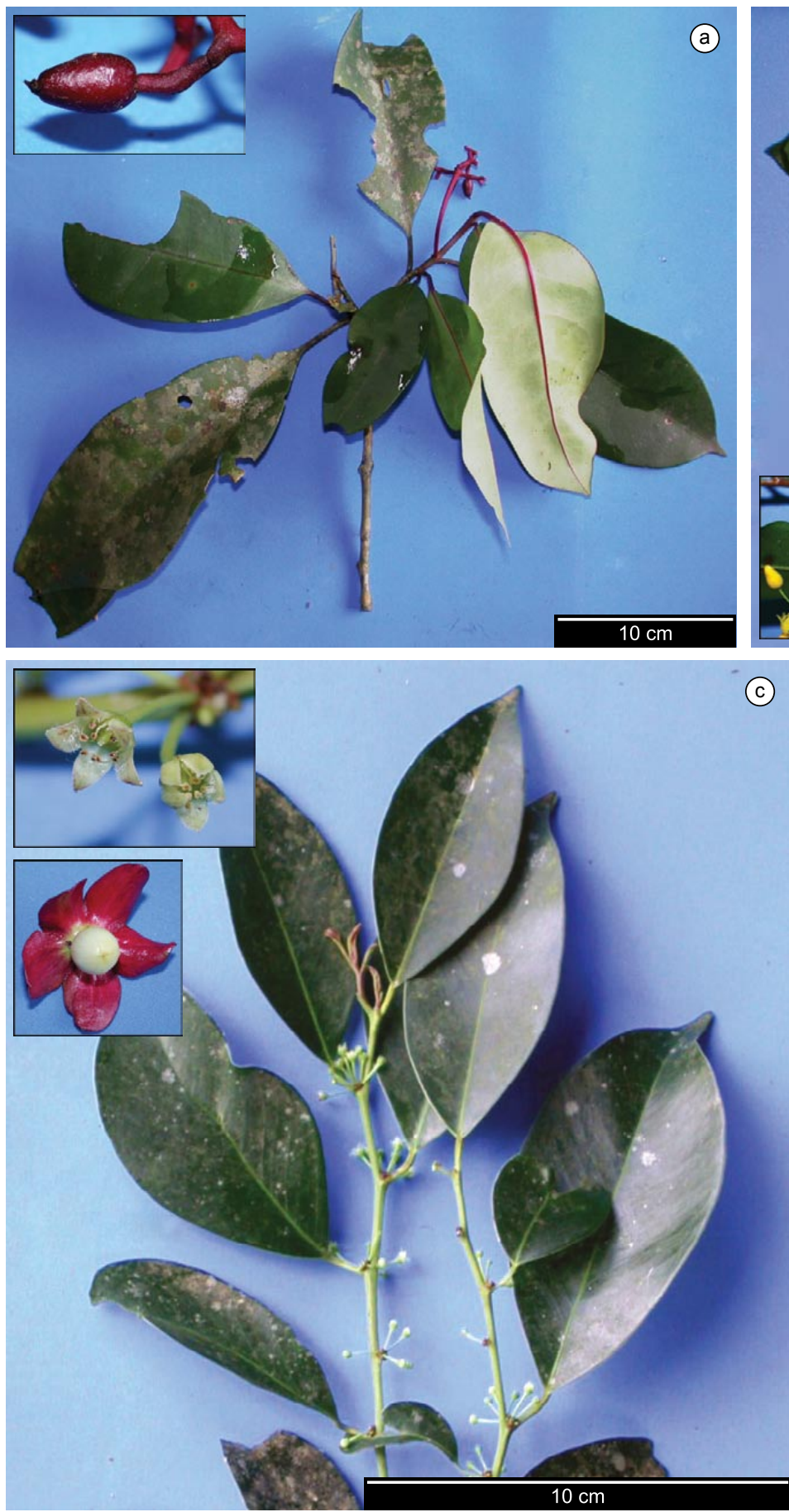

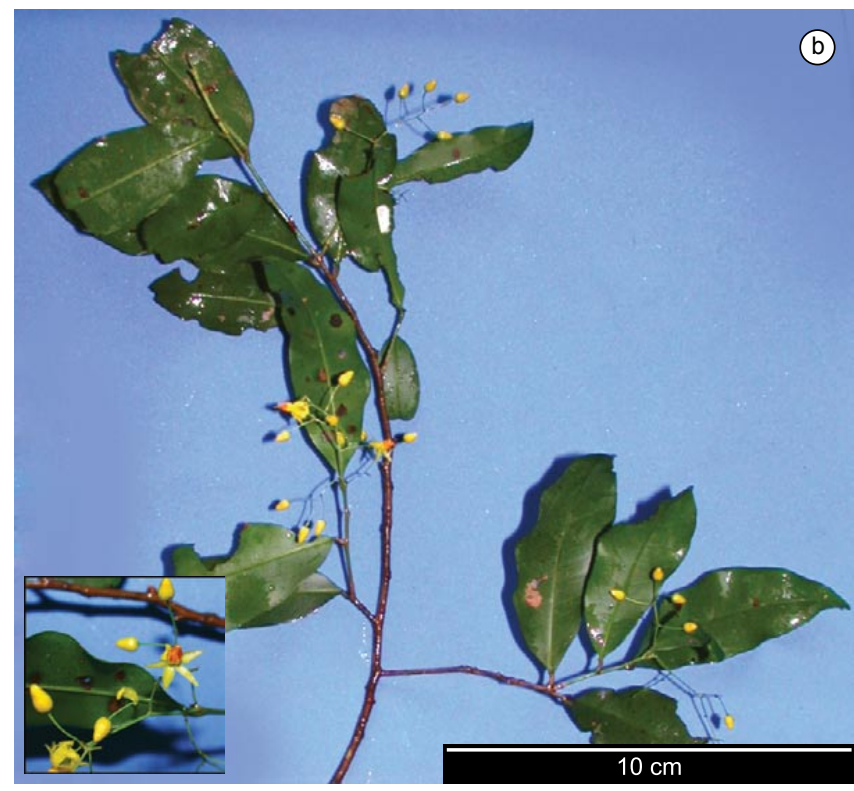

(C)

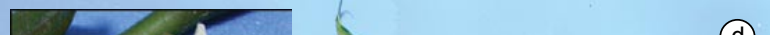

(d)

Figura 24. Nyctaginaceae: a) Neea schwackeana (C. Urbanetz 343), em destaque detalhe do fruto. Ochnaceae: b) Ouratea parviflora (C. Urbanetz 375), em destaque detalhe das flores. Olacaceae: c) Heisteria silvianii (C. Urbanetz 142), em destaque detalhes das flores e do fruto; d) Tetrastylidium grandifolium (C. Urbanetz 296), em destaque detalhe da flor.

Figure 24. Nyctaginaceae: a) Neea schwackeana (C. Urbanetz 343), fruit in detail. Ochnaceae: b) Ouratea parviflora (C. Urbanetz 375), flowers in detail. Olacaceae: c) Heisteria silvianii (C. Urbanetz 142), flowers and fruit in detail; d) Tetrastylidium grandifolium (C. Urbanetz 296), flower in detail. 
Urbanetz, C. et al.

Flamílias Phyllantaceae, Piperaceae e Rosaceae
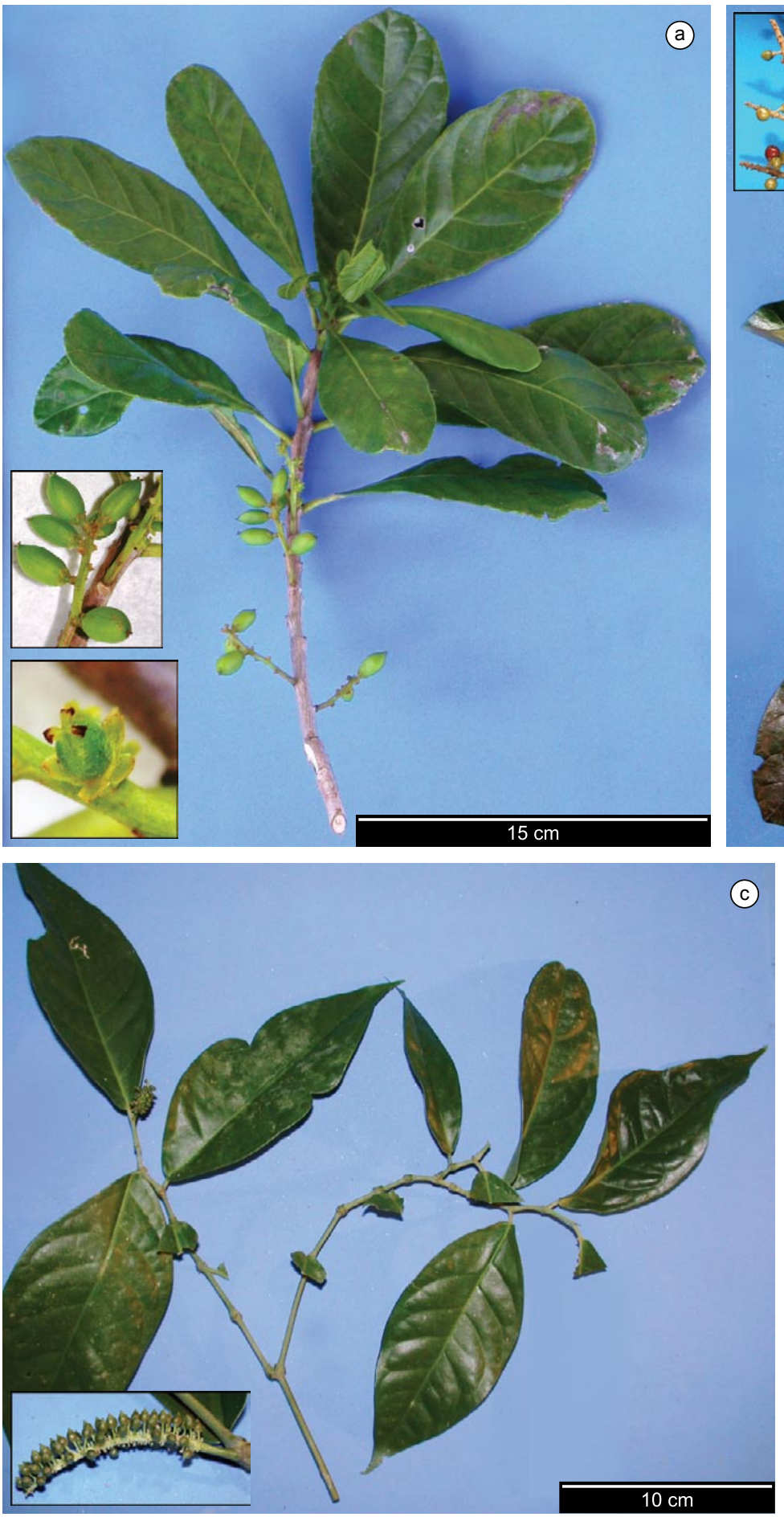

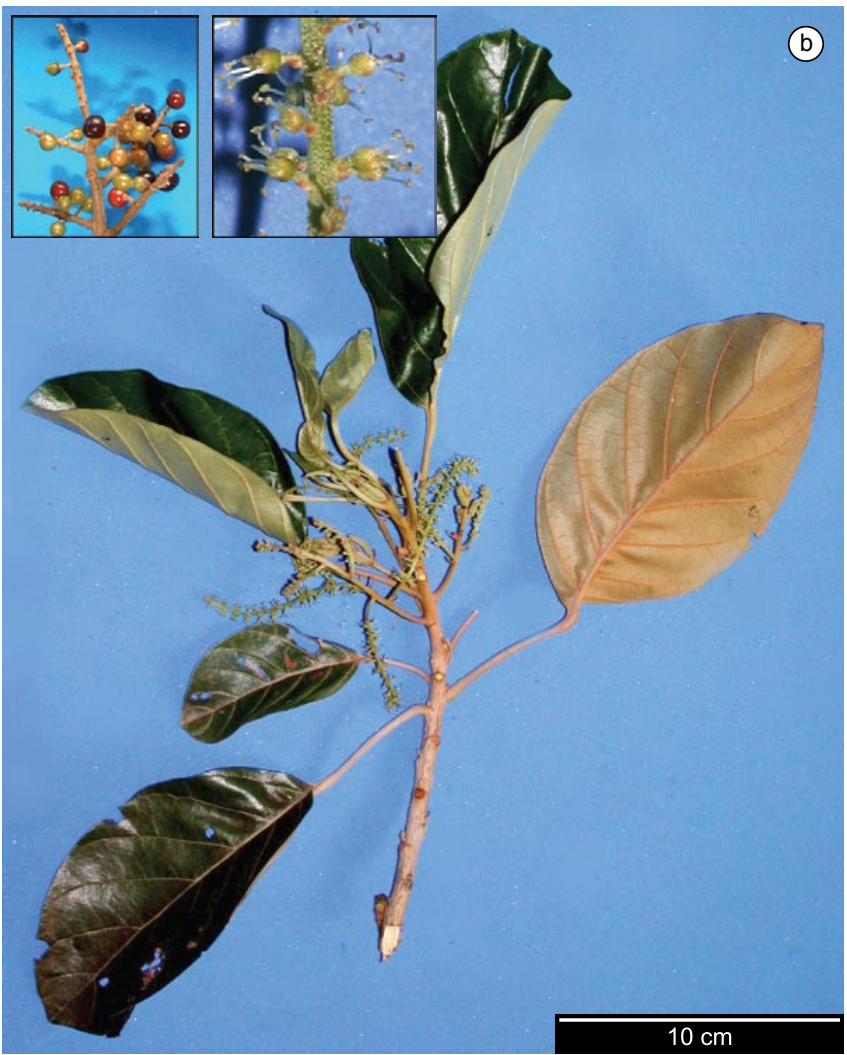

(c)

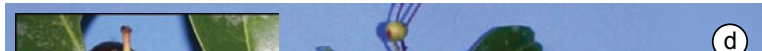

(d)

Figura 25. Phyllanthaceae: a) Richeria grandis (C. Urbanetz 130), em destaque detalhes da flor feminina e dos frutos; b) Hyeronima alchorneoides (C. Urbanetz 214), em destaque detalhes das flores e dos frutos. Piperaceae: c) Ottonia martiana (C. Urbanetz 307), em destaque detalhe do ramo com frutos. Rosaceae: d) Prunus myrtifolia (C. Urbanetz 154), em destaque detalhe dos frutos.

Figure 25. Phyllanthaceae: a) Richeria grandis (C. Urbanetz 130), female flower and fruits in detail; b) Hyeronima alchorneoides (C. Urbanetz 214), flowers and fruits in detail. Piperaceae: c) Ottonia martiana (C. Urbanetz 307), branch with fruits in detail. Rosaceae: d) Prunus myrtifolia (C. Urbanetz 154), fruits in detail. 

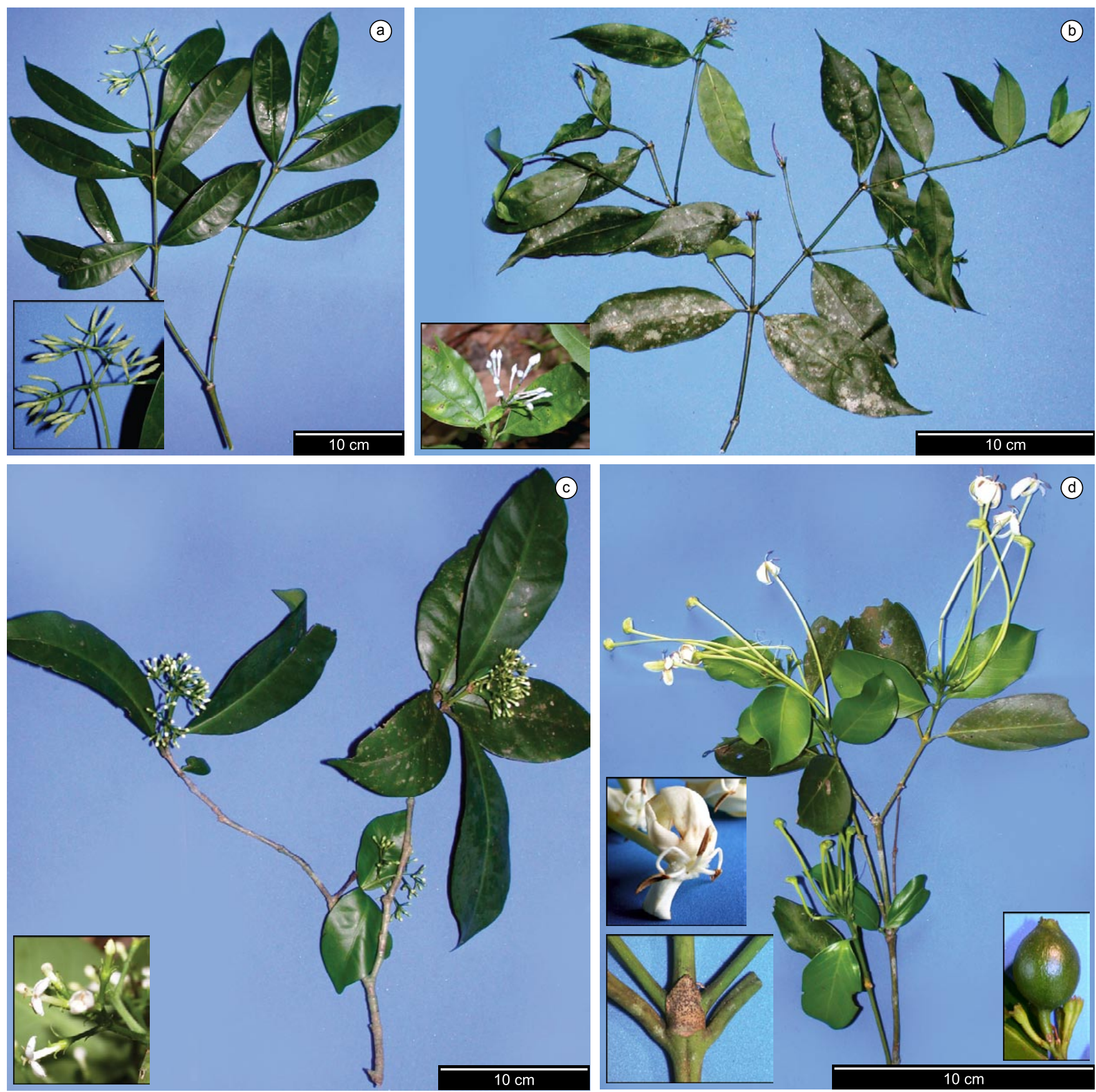

Figura 26. Rubiaceae: a) Faramea montevidensis (C. Urbanetz 262), em destaque detalhe da inflorescência; b) Faramea multiflora (C. Urbanetz 237), em destaque detalhe da inflorescência; c) Ixora heterodoxa (C. Urbanetz 371), em destaque detalhe das flores; d) Posoqueria latifolia (C. Urbanetz 213), em destaque detalhes da flor, do fruto e da estípula.

Figure 26. Rubiaceae: a) Faramea montevidensis (C. Urbanetz 262), inflorescence in detail; b) Faramea multiflora (C. Urbanetz 237), inflorescence in detail; c) Ixora heterodoxa (C. Urbanetz 371), flowers in detail; d) Posoqueria latifolia (C. Urbanetz 213), flower, fruit and stipule in detail. 
Urbanetz, C. et al.

Família Rubiaceae
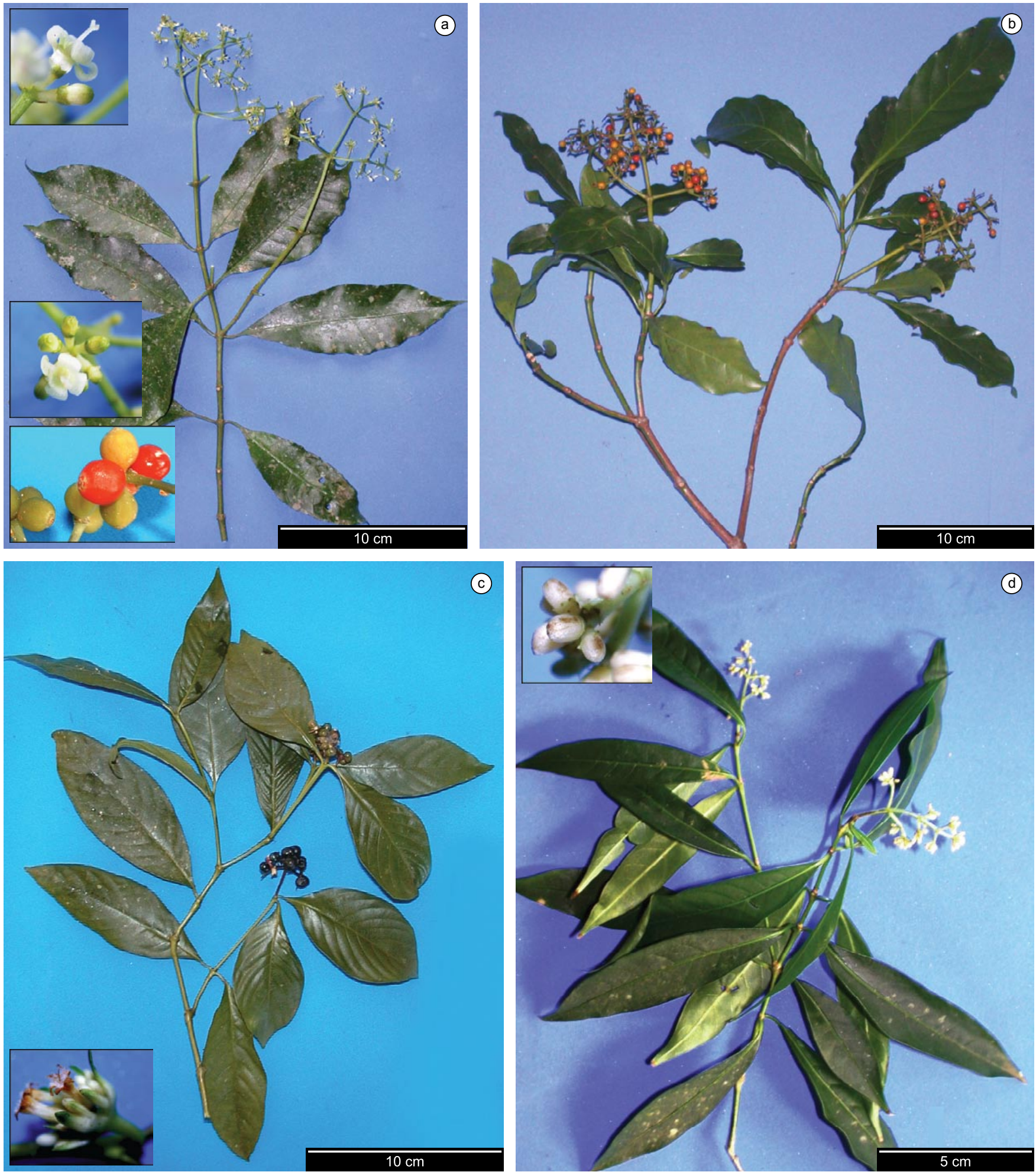

Figura 27. Rubiaceae: a) Psychotria birotula (C. Urbanetz 272), em destaque detalhes das flores e dos frutos; b) Psychotria carthagenensis (C. Urbanetz 14); c) Psychotria gracilenta (C. Urbanetz 401), em destaque detalhe da inflorescência; d) Psychotria leiocarpa (C. Urbanetz 219), em destaque detalhe dos botões.

Figure 27. Rubiaceae: a) Psychotria birotula (C. Urbanetz 272), flowers and fruits in detail; b) Psychotria carthagenensis (C. Urbanetz 14); c) Psychotria gracilenta (C. Urbanetz 401), inflorescence in detail; d) Psychotria leiocarpa (C. Urbanetz 219), buds in detail. 

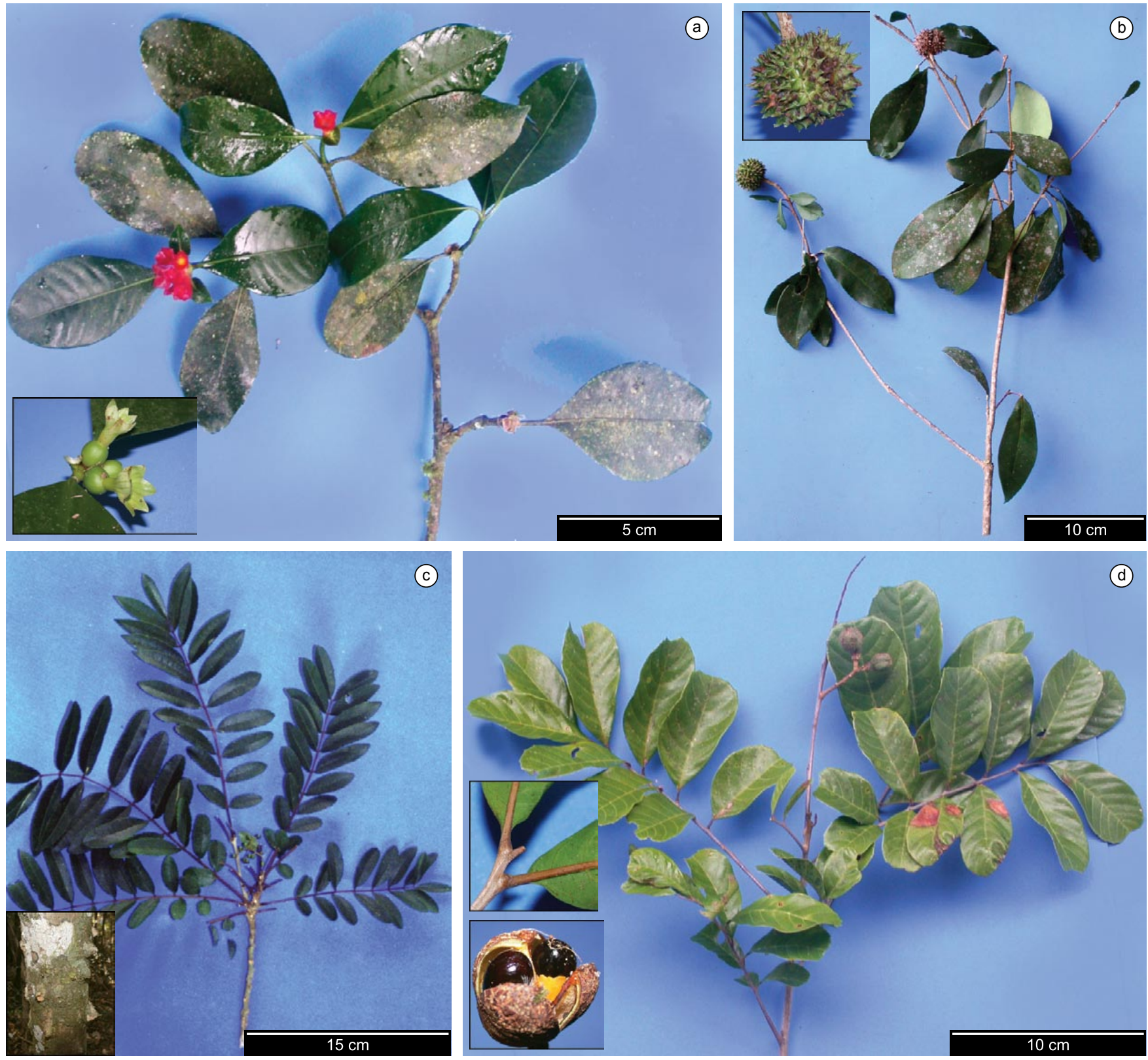

Figura 28. Rubiaceae: a) Psychotria nuda (C. Urbanetz 5), em destaque detalhe dos frutos imaturos. Rutaceae: b) Esenbeckia grandiflora (C. Urbanetz 138), em destaque detalhe do fruto; c) Zanthoxylum rhoifolium (C. Urbanetz 373), em destaque o tronco. Sapindaceae: d) Cupania oblongifolia (C. Urbanetz 93), em destaque detalhes do fruto e da parte distal da folha.

Figure 28. Rubiaceae: a) Psychotria nuda (C. Urbanetz 5), immature fruits in detail. Rutaceae: b) Esenbeckia grandiflora (C. Urbanetz 138), fruit in detail; c) Zanthoxylum rhoifolium (C. Urbanetz 373), trunk in detail. Sapindaceae: d) Cupania oblongifolia (C. Urbanetz 93), fruit and distal portion of the leave in detail. 
Urbanetz, C. et al.
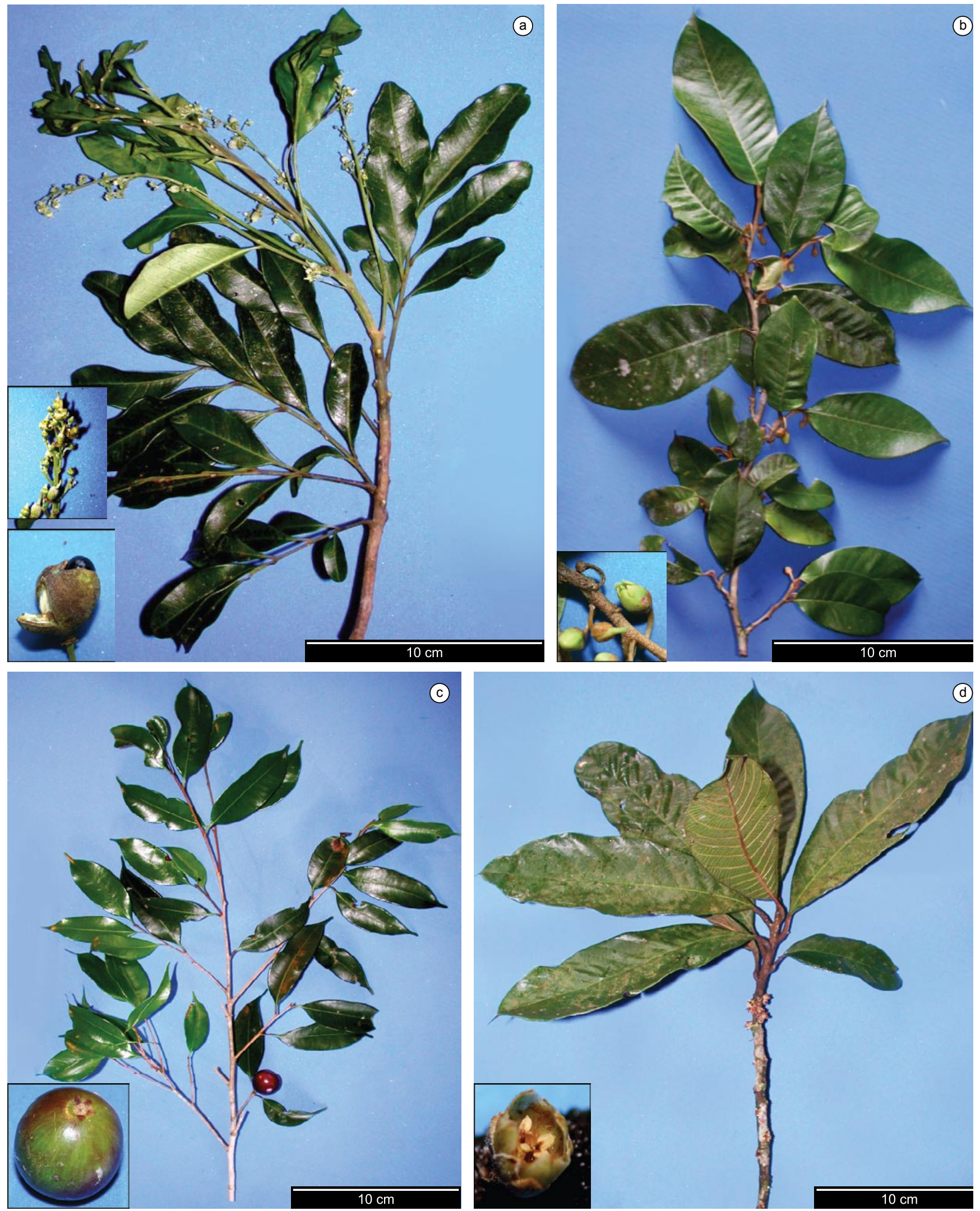

Figura 29. Sapindaceae: a) Matayba intermedia (C. Urbanetz 212), em destaque detalhes da inflorescência e do fruto. Sapotaceae: b) Chrysophyllum flexuosum (C. Urbanetz 302), em destaque detalhe das flores; c) Diploon cuspidatum (C. Urbanetz 331), em destaque detalhe do fruto; d) Ecclinusa ramiflora (C. Urbanetz 260), em destaque detalhe da flor.

Figure 29. Sapindaceae: a) Matayba intermedia (C. Urbanetz 212), inflorescence and fruit in detail. Sapotaceae: b) Chrysophyllum flexuosum (C. Urbanetz 302), flowers in detail; c) Diploon cuspidatum (C. Urbanetz 331), fruit in detail; d) Ecclinusa ramiflora (C. Urbanetz 260), flower in detail. 

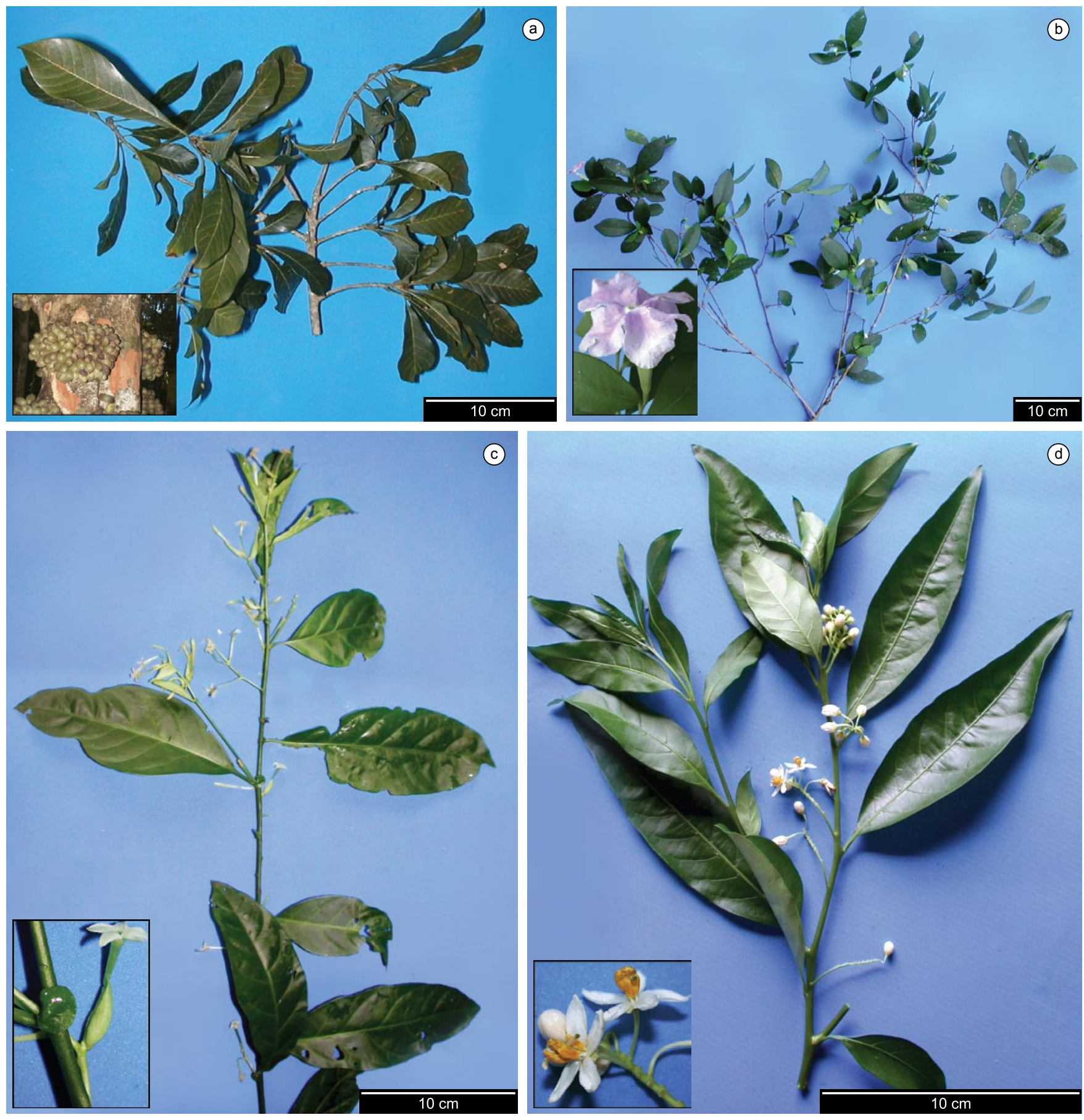

Figura 30. Sapotaceae: a) Pradosia lactescens (C. Urbanetz 380), em destaque tronco com frutos. Solanaceae: b) Brunfelsia pauciflora (C. Urbanetz 282), em destaque detalhe da flor; c) Cestrum sessiliflorum (C. Urbanetz 335), em destaque detalhe da flor; d) Solanum pseudoquina (C. Urbanetz 304), em destaque detalhe da flor.

Figure 30. Sapotaceae: a) Pradosia lactescens (C. Urbanetz 380), trunk with fruits in detail. Solanaceae: b) Brunfelsia pauciflora (C. Urbanetz 282), flower in detail; c) Cestrum sessiliflorum (C. Urbanetz 335), flower in detail; d) Solanum pseudoquina (C. Urbanetz 304), flower in detail. 

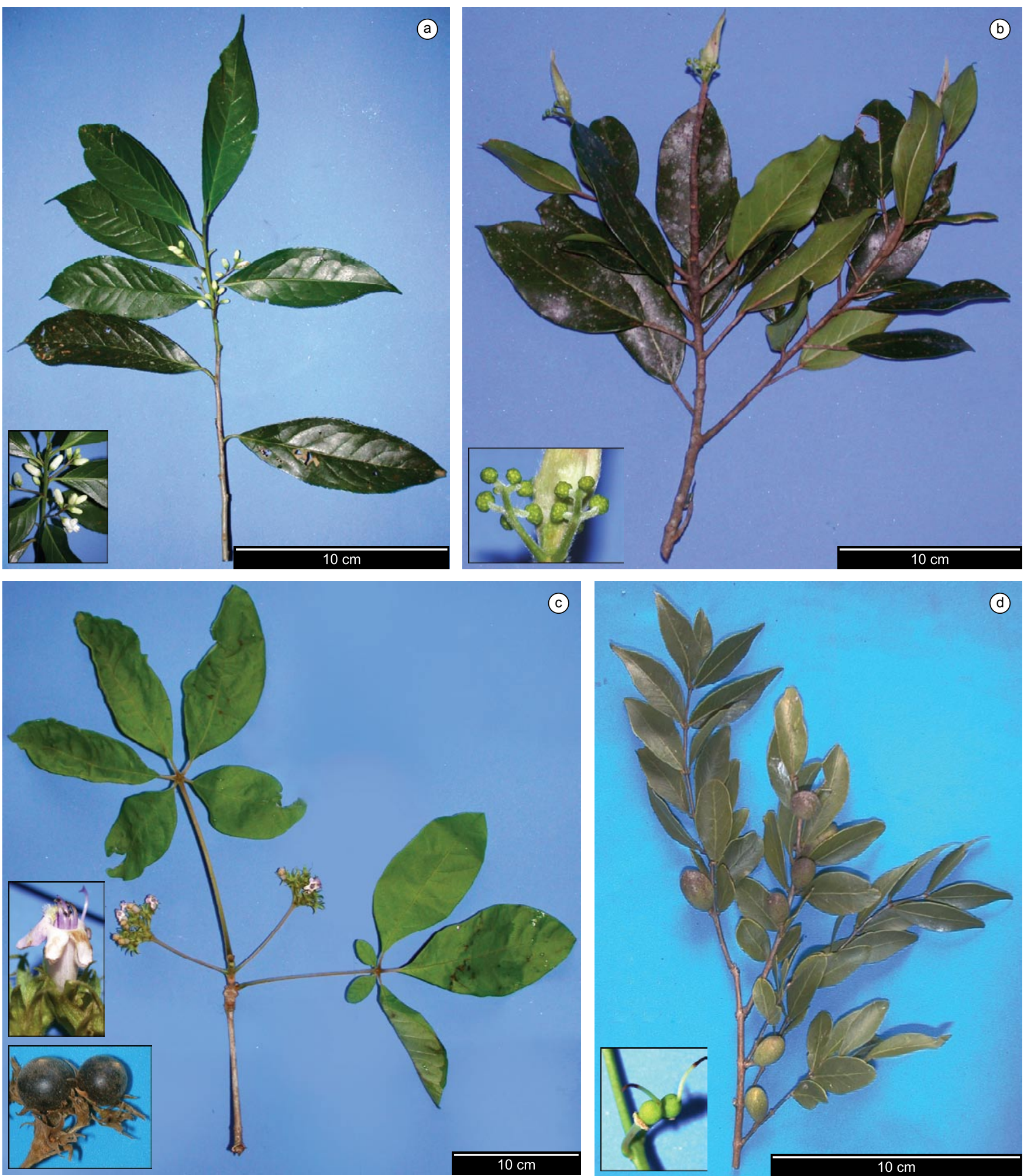

(d)

Figura 31. Symplocaceae: a) Symplocos laxiflora (C. Urbanetz 270), em destaque detalhe da inflorescência. Urticaceae: b) Coussapoa microcarpa (C. Urbanetz 156), em destaque detalhe da inflorescência. Verbenaceae: c) Vitex polygama (C. Urbanetz 256), em destaque detalhes da flor e dos frutos. Vochysiaceae: d) Callisthene kuhlmmanii (C. Urbanetz 151), em destaque detalhe da flor sem perianto.

Figure 31. Symplocaceae: a) Symplocos laxiflora (C. Urbanetz 270), inflorescence in detail. Urticaceae: b) Coussapoa microcarpa (C. Urbanetz 156), inflorescence in detail. Verbenaceae: c) Vitex polygama (C. Urbanetz 256), flower and fruits in detail. Vochysiaceae: d) Callisthene kuhlmmanii (C. Urbanetz 151), flower without perianth in detail. 


\section{Agradecimentos}

Os autores agradecem à CAPES pela bolsa concedida ao primeiro autor, uma vez que o trabalho é parte da dissertação de Mestrado apresentada pelo primeiro autor junto ao programa de Pós-Graduação em Biologia Vegetal (UNICAMP), à PROAP/CAPES pelas diárias, aos proprietários da Fazenda Folha Larga pelo apoio logístico, aos taxonomistas pelas identificações realizadas: A. B. Martins (Melastomataceae), E. Lucas (Myrtaceae), I. Cordeiro (Euphorbiaceae), J. B. Baitello, P. L. R. Moraes e T. D. M. Barbosa (Lauraceae), J. E. C. Meireles (Fabaceae), J. Semir (Asteraceae), L. C. Bernacci (Arecaceae), M. Moraes (Asteraceae), M. Sobral (Myrtaceae), S. L. Jung-Mendaçolli (Rubiaceae), S. Romaniuc Neto (Moraceae) e I. R. Costa pela colaboração com a parte de Myrtaceae da chave.

\section{Referências Bibliográficas}

ALENCAR, J.C. 1998. Identificação botânica de árvores de Floresta Tropical Úmida da Amazônia por meio de computador. Acta. Amaz. 28(1):3-30.

APG - THE ANGIOSPERM PHYLOGENY GROUP. 2003. An update of the Angiosperm Phylogeny Group classification for the orders and families of flowering plants: APG II. Botanical Journal of the Linnean Society 141: 399-436.

BATALHA, M.A., ARAGAKI, S. \& MANTOVANI, W. 1998. Chave de identificação das espécies vasculares de cerrado em Emas (Pirassununga, SP) baseada em caracteres vegetativos. Bol. Bot. Univ. São Paulo 17:85-108.

BRAZ, D.M., MOURA, M.V.L.P.M. \& ROSA, M.M.T. 2004. Chave de identificação para as espécies de Dicotiledôneas arbóreas da Reserva Biológica do Tinguá, RJ, com base em caracteres vegetativos. Acta Bot. Bras. 18(2):225-240.

BRUMMIT, R.K. \& POWELL, C.E. 1992. Authors of plant names. Royal Botanic Gardens, Kew, 732p.

COUTINHO, A.P.S. 2004. Guia ilustrado de identificação para espécies arbóreas em uma parcela permanente no cerradão da Estação Ecológica de Assis, município de Assis (SP). Dissertação de mestrado, Universidade de São Paulo - Esalq, Piracicaba.

DALLWITZ, M.J., PAINE, T.A. \& ZURCHER, E.J. 1984. 'User's Guide to the DELTA System: a General System for Coding Taxonomic Descriptions.' 2nd edition. CSIRO Aust. Div. Entomol. Rep. No. 13:1-93.

DUARTE, A.R. 2003. Espécies de Myrtaceae de uma parcela permanente de Floresta Ombrófila Densa Baixo Montana no Parque Estadual de Carlos Botelho, município de Sete Barras, SP. Dissertação de mestrado, Universidade de São Paulo - Esalq, Piracicaba.

EDWARDS, M. \& MORSE, D.R. 1995. The potential for computer-aided identification in biodiversity research. Tree 10:153-158.

FERRI, M.G., MENEZES, N.L. \& MONTEIRO, W.R. 1981. Glossário ilustrado de botânica. Nobel, São Paulo, 113p.

FONT QUER, P. 1985. Dicionário de botânica. Labor, Barcelona, 1244p.

FREITAS, C.V. \& OLIVEIRA, P.E. 2002. Biologia reprodutiva de Copaifera langsdorffii Desf. (Leguminosae, Caesalpinioideae). Rev. Bras. Bot. 25(3):311-321.

GARCIA, F.C.P. 1998. Relações sistemáticas e fitogeografia de Inga Miller (Leguminosae-Mimosoideae) nas florestas da costa sul e sudeste do Brasil. Tese de doutorado, Universidade Estadual Paulista, Rio Claro.

GENTRY, A.H. 1993. A field guide to the families and genera of woody plants of Northwest South América (Colômbia, Ecuador, Peru) with supplementary notes on herbaceous taxa. Conservation International, Washington, 895p

GUEDES-BRUNI, R.R., PESSOA, S.V.A. \& KURTZ, B.C. 1997. Florística e estrutura do componente arbustivo-arbóreo de um trecho preservado de floresta montana na Reserva Ecológica de Macaé de Cima. In Serra de Macaé de Cima: diversidade florística e conservação em Mata Atlântica
(H.C. Lima \& R.R. Guedes-Bruni, eds.). Jardim Botânico do Rio de Janeiro, Rio de Janeiro, p.127-146.

KOEPPEN, W. 1948. Climatologia: com um estudio de los climas de la terra. Fundo de Cultura Economica, México, 479p.

LEPSCH, I.F., SAKAI, E., PRADO, H., MENK, J.R.F., SAKAI, E. \& RIZZO, L.T.B. 1999. Levantamento de reconhecimento com detalhes dos solos da região do Rio Ribeira de Iguape no Estado de São Paulo. Escala 1: 250.000. Governo do Estado de São Paulo, Secretaria de Agricultura e Abastecimento, Instituto Agronômico, Campinas.

LIMA, M.P., GUEDES-BRUNI, R.R., VIEIRA, C.M., CORREIA, C.M.B. \& ARAÚJO, I.A. 1994. Identificação das famílias com espécies arbóreas. In Reserva ecológica de Macaé de Cima, Nova Friburgo - RJ, aspectos florísticos das espécies vasculares (M.P. Lima \& R.R. Guedes-Bruni, orgs.). Jardim Botânico do Rio de Janeiro, Rio de Janeiro, v. 1, p. 61-74.

LUCIDCENTRAl. Lucid software. http://www.lucidcentral.com/Home/ AboutUs/tabid/204/Default.aspx (último acesso em 21/03/2009).

MANTOVANI, W., LEITÃO-FILHO, H.F. \& MARTINS, F.R. 1985. Chave baseada em caracteres vegetativos para identificação de espécies lenhosas do cerrado da Reserva Biológica de Mogi Guaçu, Estado de São Paulo. Hoehnea 12:35-56.

MARTINS, A.B., SEMIR, J., GOLDENBERG, R. \& MARTINS, E. 1996. O gênero Miconia Ruiz \& Pav. (Melastomataceae) no Estado de São Paulo. Acta Bot. Bras. 10(2):267-316.

MOBOT. Missouri Botanical Garden Website. http://www.tropicos.org/ (ultimo acesso em 31/07/2009).

NEWSTRON, L.E., FRANKIE, G.W., BAKER, H.G. 1994. A new classification for plant phenology based on flowering patterns in lowland Tropical Rain Forest trees at La Selva, Costa Rica. Biotropica 26(2):141-159.

RADFORD, A.E., DICKISON, W.C., MASSEY, J.R. \& BELL, C.R. 1974 Vascular Plant Sistematics. Harper \& Row Publishers, New York, 891p.

REJMÁNEK, M. \& BREWER, S.W. 2001. Vegetative identification of Tropical woody plants: state of the art and annotated biography. Biotropica 33(2):214-228.

RIBEIRO, J.E.L.S., HOPKINS, M.J.G., VICENTINI, A., SOTHERS, C.A., COSTA, M.A.S., BRITO, J.M., SOUZA, M.A.D., MARTINS, L.H.P., LOHMANN, L.G., ASSUNÇÃO, P.A.C.L., PEREIRA, E.C., SILVA, C.F., MESQUITA, M.R. \& PROCOPIO, L.C. 1999. Flora da Reserva Ducke. Guia de identificação das plantas vasculares de uma floresta de terra-firme na Amazônia Central. Instituto Nacional de Pesquisas da Amazônia, Manaus, 816p.

ROSSI, L. 1994. A flora arbóreo-arbustiva da Reserva da Cidade Universitária "Armando Salles de Oliveira" (São Paulo, Brasil). Bol. Inst. Bot. 9:1-105.

SANTOS, K. 1998. Flora arbustivo-arbórea do fragmento de floresta estacional semidecidual no Ribeirão Cachoeira, Campinas, SP. Dissertação de mestrado, Universidade Estadual de Campinas, Campinas.

SMITH, R.F. 1975. Ecología de las plantas leñosas del espinar de los estados Lara y Falcón de Venezuela y clave ilustrada en base a sus características vegetativas. Acta Bot. Venez. 10:87-129.

SMITH, R.F., CASADIEGO, J.A., SANABRIA, M.E. \& GARCÍA, F.Y. 1996. Clave para los árboles de los Llanos de Venezuela basada en características vegetativas. Sociedad Venezolana de Ciencias Naturales, Caracas, Venezuela, 315p.

SPICHIGER, R. 1982. Prueba de clave para reconocer, a partir de los órganos vegetativos, las principales familias de árboles de una reserva natural de la Amazonia peruana. Saussurea 13:1-16.

STUTZ, L.C. 1984. Etudes floristiques de divers states secondaires des formations forestières du Haut Parana (Paraguay oriental) Clé de détermination des espèces ligneuses forestières à l'aide de caractères végétatifs juvéniles. Candollea 39:71-102.

The International Plant Names Index - IPNI. http://www.ipni.org/ (último acesso em 02/07/2009) 
TORRES, R.B., KINOSHITA, L.S. \& MARTINS, F.R. 1994. Aplicação de padrões de casca na identificação de árvores da Estação Ecológica de Angatuba, SP. Rev. Bras. Bot. 17:119-127.

URBANETZ, C. 2005. Estudos Florísticos da Floresta Ombrófila Densa Atlântica da Fazenda Folha Larga, Cananéia, SP. Dissertação de Mestrado, Universidade Estadual de Campinas, Campinas.

VELOSO, H.P., OLIVEIRA FILHO, L.C., VAZ, A.M.S.F., LIMA, M.P.M. MARQUETE, R. \& BRAZÃO, J.E.M. (orgs.). 1992. Manual técnico da vegetação brasileira. Manuais técnicos em Geociências. IBGE, Rio de Janeiro, v. 1, p. 1-91.

VOSS, E.G. 1952. The history of keys and phylogenetic trees in systematic biology. J. Sct. Denison Unw. 43(1952):1-25.

WANDERLEY, M.G.L., SHEPHERD, G.J. \& GIULIETTI, A.M. (coord.). 2002. Flora Fanerogâmica do Estado de São Paulo. FAPESP/HUCITEC, São Paulo, v. 2, 391p.
WANDERLEY, M.G.L., SHEPHERD, G.J., GIULIETTI, A.M. \& MELHEM, T.S. (coord.). 2003. Flora Fanerogâmica do Estado de São Paulo. FAPESP/ RiMa, São Paulo, v. 3, 367p.

WANDERLEY, M.G.L., SHEPHERD, G.J., MELHEM, T.S. \& GIULIETTI, A.M. (coord.). 2005. Flora Fanerogâmica do Estado de São Paulo. FAPESP/RiMa, São Paulo, v. 4, 408p.

WANDERLEY, M.G.L., SHEPHERD, G.J., MELHEM, T.S. \& GIULIETTI, A.M. (coord.). 2007. Flora Fanerogâmica do Estado de São Paulo. FAPESP/Instituto de Botânica, São Paulo, v. 5, 476p.

WANDERLEY, M.G.L., SHEPHERD, G.J., MELHEM, T.S. \& GIULIETTI, A.M. (Coord.). 2009. Flora Fanerogâmica do Estado de São Paulo. São Paulo: FAPESP/Instituto de Botânica, São Paulo, v.6.

Recebido em 20/10/09 Versão reformulada recebida em 27/03/10 Publicado em 19/04/10 


\section{Anexo 1}

Anexo 1. Chave de identificação de espécies lenhosas de um trecho de Floresta Ombrófila Densa Atlântica, no Sudeste do Brasil, baseada em caracteres vegetativos.

Appendix 1. Identification key for woody species of an Atlantic Rain Forest remnant, in the Southeast of Brazil, based on vegetative characters.

1. Plantas com caule sem ramificações visíveis na porção aérea (monocotiledôneas - Arecaceae)

Chave 1

2. Plantas com caule ramificado e folhas compostas (Araliaceae, Bignoniaceae, Burseraceae, Cunoniaceae, Fabaceae, Malvaceae, Meliaceae, Rutaceae, Sapindaceae e Verbenaceae)

Chave 2

3. Plantas com caule ramificado; folhas simples com disposição verticilada, oposta e/ou suboposta (Apocynaceae, Clusiaceae, Elaeocarpaceae, Lauraceae, Melastomataceae, Monimiaceae, Myrtaceae, Nyctaginaceae, Rubiaceae, Rutaceae, Sapotaceae, Vochysiaceae e Verbenaceae).....

Chave 3

4. Plantas com caule ramificado; folhas simples com disposição alterna (Annonaceae, Apocynaceae, Aquifoliaceae, Asteraceae, Boraginaceae, Cecropiaceae, Clethraceae, Celastraceae, Chrysobalanaceae, Erythroxylaceae, Euphorbiaceae, Fabaceae, Humiriaceae, Lacistemataceae, Lauraceae, Moraceae, Myristicaceae, Myrsinaceae, Ochnaceae, Olacaceae, Phyllanthaceae, Piperaceae, Polygonaceae, Rosaceae, Rutaceae, Salicaceae, Sapotaceae, Solanaceae, Symplocaceae, Thymelaeaceae, Urticaceae) . Chave 4

\section{Chave 1 - Plantas com caule sem ramificações visíveis na porção aérea (Monocotiledôneas - família Arecaceae)}

1'. Planta com espinhos 2

1. Planta sem espinhos 4

2. Folhas com o par de pinas terminais com largura semelhante às demais Astrocaryum aculeatissimum

2'. Folhas com o par de pinas terminais mais largas que as demais 3

3. Folhas verdes em ambas as faces Bactris setosa

3'. Folhas com superfície abaxial acinzentada Bactris hatschbachii

4. Plantas adultas com altura inferior a $5 \mathrm{~m}$ e diâmetro à altura do peito $<8 \mathrm{~cm}$ Geonoma gamiova (Figura 3b)

4'. Plantas adultas com altura superior a $5 \mathrm{~m}$ e diâmetro à altura do peito $>8 \mathrm{~cm}$ .5

5. Folhas com pinas distribuídas no mesmo plano da raque, ligeiramente rígidas, raque de até $2,5 \mathrm{~m}$ compr Euterpe edulis

5'. Folhas com pinas distribuídas em vários planos da raque, nunca rígidas, raque de até 4,5 m compr. Attalea dubia

\section{Chave 2 - Plantas com caule ramificado e folhas compostas}

1. Filotaxia oposta 2

1'. Filotaxia alterna 5

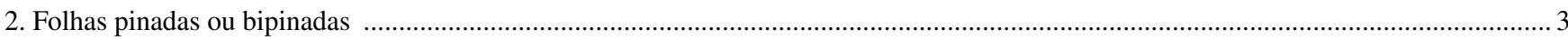

2'. Folhas palmadas 4

3. Folha pinada com a raque alada, estípula interpeciolar presente e caduca Weinmannia paulliniifolia (Figura 7a)

3'. Folha bipinada com raque não alada, estípula ausente Jacaranda puberula

4. Tronco esfoliante; comprimento do pecíolo maior ou igual ao do limbo foliar, folíolo com ápice obtuso, tricomas foliares simples Vitex polygama (Figura 31c)

4. Tronco não esfoliante; comprimento do pecíolo menor que o do limbo foliar, folíolo com ápice agudo ou acuminado, tricomas foliares estrelados .Tabebuia umbellata

5. Folhas sem raque 6

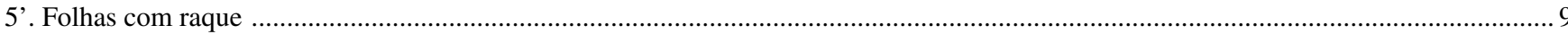

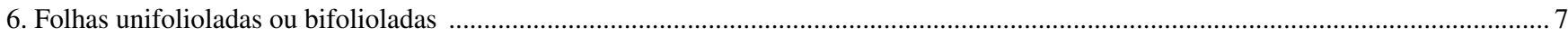

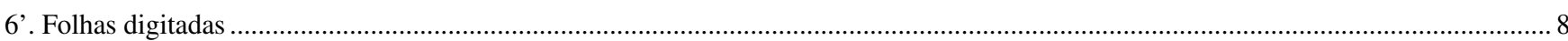

7. Folhas unifolioladas, com espessamento no ápice dos pecíolos Esenbeckia grandiflora (Figura 28b)

7’. Folhas bifolioladas, sem espessamento do ápice dos pecíolos Hymenaea courbaril (Figura 10a) 
Urbanetz, C. et al.

\section{Anexo 1. Continuação...}

8. Folíolos elípticos ou elíptico-lanceolados, com tricomas abundantes na face abaxial, discolores, nervura central enegrecida no material herborizado

8'. Folíolos obovais, glabros em ambas as faces, concolores, com nervura central marrom no material herborizado

Pseudobombax grandiflorum

9. Folhas bipinadas..... 10

9'. Folhas pinadas

10. Árvores com tronco marrom, rugoso e suberoso; pecíolo com nectário extra-floral.....

Baliziapedicellaris (Figura9b)

10'. Árvore com tronco acinzentado, liso e com cicatrizes foliares no caule e ramos; pecíolo sem nectário extra-floral.

Schizolobium parahyba (Figura 11c)

11. Tronco e ramos com espinhos; folhas com glândulas translúcidas no limbo, bordo dos folíolos crenado

Zanthoxylum rhoifolium (Figura 28c)

11'. Tronco e ramos sem espinhos; folhas sem glândulas translúcidas no limbo, bordo dos folíolos inteiro

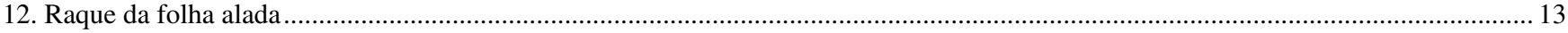

12'. Raque da folha sem ala ......

13. Glândulas entre os pares de folíolos 1,5-4 mm compr., circular ou transversalmente comprimida .Inga edulis (Figura 10b) / Inga sessilis (Figura 10d)

13'. Glândulas entre os pares de folíolos 0,5-1 mm compr., circular, nunca transversalmente comprimida .....

Inga vera (Figura 11a) / Inga striata

14. Folhas imparipinadas .15

14'. Folhas paripinadas

15. Folíolos com disposição alterna

15'. Folíolos com disposição oposta

16. Raque com folíolo terminal

Pterocarpus rohrii (Figura 11b)

16'. Raque com uma estrutura pontiaguda lateralmente ao folíolo

17. Folíolos com margem inteira

Matayba intermedia (Figura 29a)

17'. Folíolos com margem serreada

Cupania oblongifolia (Figura 28d)

18. Estipelas presentes nos folíolos

Andira fraxinifolia (Figura 9a)

18 '. Estipelas ausentes nos folíolos

19. Folíolos glabros

19’. Folíolos com indumento

20. Folhas não odoríferas, com pulvínulo Dahlstedtia pinnata (Figura 9d)

20'. Folhas odoríferas, sem pulvínulo .Protium heptaphyllum

21. Folíolos adultos com 7-16(-18) cm compr., com pontuações translúcidas Centrolobium tomentosum (Figura 9c)

21'. Folíolos adultos com 4-8 cm compr., sem pontuações translúcidas Swartzia submarginata (Figura 12c)

22. Pecíolo ou raque com nectários extra-florais 23

22'. Pecíolo ou raque sem nectários extra-florais 25

23. Nectário com formato de gota Sennamultijuga(Figura12a)

23'. Nectário com formato de prato

24. Folíolos com indumento .Inga bullata

24'. Folíolos sem indumento. Inga lanceifolia (Figura 10c)

25. Folha com estípulas ou cicatrizes estipulares 26

$25^{\prime}$. Folha sem estípulas 28

26. Folíolos romboidais, com base fortemente assimétrica

Copaifera trapezifolia 
Anexo 1. Continuação...

26'. Folíolos elípticos ou ovais, com base simétrica ou apenas levemente assimétrica

27. Folíolos elípticos, coriáceos, de 3-4 pares, com base aguda.....

Sclerolobium denudatum (Figura 11d)

27'. Folíolos ovais, membranáceos ou cartáceos, de 8-12 pares, com base arredondada. Senna silvestris (Figura 12b)

28. Porção distal da folha com folíolos não desenvolvidos assemelhando-se a uma folha não desenvolvida incurvada, pilosa, folíolos com indumento na face abaxial Guarea macrophylla (Figura 17d)

28. Porção distal da folha com os folíolos terminais desenvolvidos, folíolos sem indumento na face abaxial ou com indumento apenas na nervura central

29. Tronco liso; folhas com 6-12 pares de folíolos, presença de domácias

Cabralea canjerana (Figura 17c)

29'. Tronco fissurado longitudinalmente; folhas com 12-18 pares de folíolos, ausência de domácias Cedrela fissilis (Figura 18a)

\section{Chave 3 - Plantas com caule ramificado, folhas simples com disposição verticilada, oposta e/ou suboposta}

1. Filotaxia verticilada 2

1'. Filotaxia oposta e/ou suboposta 3

2. Base do limbo com um par de nectários extra-florais Citharexylum myrianthum

2'. Base do limbo sem nectários extra-florais Vochysia bifalcata

3. Ramos com folhas opostas e/ou subopostas .4

3'. Ramos com folhas exclusivamente opostas 9

4. Pecíolo com engrossamento na parte distal 5

4'. Pecíolo sem engrossamento na parte distal 6

5. Plantas com raízes tabulares; folhas simples, sem pontuações translúcidas no limbo, axilas das nervuras secundárias da folha com domácias em tufos de tricomas Sloanea guianensis

5'. Plantas sem raízes tabulares; folhas unifolioladas, com pontuações translúcidas no limbo, axilas das nervuras secundárias da folha sem domácias em tufos de tricomas Esenbeckia grandiflora (Figura 28b)

6. Folhas com indumento ferrugíneo na face abaxial . Nectandra oppositifolia (Figura 14b)

6'. Folhas glabras ou glabrescentes

7. Margem da folha serreada no terço superior Mollinedia boracensis/Mollinedia schottiana (Figura 18b)

7'. Margem da folha inteira 8

8. Pecíolo de cor bordô .Neea schwackeana (Figura 24a)

8'. Pecíolo com coloração marrom ou verde Guapira opposita (Figura 23d)

9. Látex esbranquiçado presente 10

9'. Látex ausente, ou quando presente translúcido 11

10. Ramos não dicotômicos, ramos jovens de coloração marrom claro; folhas obovais, com nervuras secundárias pouco evidentes, canais laticíferos aparentes na face abaxial Clusia criuva (Figura 6c)

10'. Ramos dicotômicos, ramos jovens com coloração negra; folhas elípticas ou elíptico-lanceoladas, com nervuras secundárias evidentes, sem canais laticíferos aparentes na face abaxial Malouetia arborea (Figura 1d)

11. Planta com raízes tabulares; pecíolo com engrossamento nas partes proximais e distais, axilas das nervuras secundárias com domácias em tufos de tricomas Sloanea guianensis

11'. Planta sem raízes tabulares; ausência de engrosssamento das extremidades do pecíolo, axilas das nervuras secundárias com domácias, ou não

12. Estípulas intra ou interpeciolares

12'. Estípulas axilares ou ausentes

13.Estípulas intrapeciolares Byrsonima ligustrifolia (Figura 15a)

13'. Estípulas interpeciolares (Rubiaceae) 14

14. Plantas armadas 
Anexo 1. Continuação...

14'. Plantas inermes

15. Folhas com domácias

15'. Folhas sem domácias

16. Folhas coriáceas, domácias sem tricomas.

Psychotria carthagenensis (Figura 27b) / Psychotria mapourioides

16’. Folhas cartáceas a membranáceas, domácias com tricomas

Rudgea recurva

17. Estípulas simples não aristadas

.Posoqueria latifolia (Figura 26d)

17’. Estípulas bífidas ou simples aristadas .....

18. Estípulas simples aristadas

18'. Estípulas bífidas

19. Estípulas com comprimento da arista menor do que o da bainha.

Ixora heterodoxa (Figura 26c)

19'. Estípulas com comprimento da arista maior ou igual do que o da bainha

.Faramea montevidensis (Figura 26a) / Faramea multiflora (Figura 26b)

20. Lobos da estípula caducos

20'. Lobos da estípula persistentes

21. Indivíduos adultos de 1,5 m alt.; folhas elípticas ou obovadas, membranáceas a cartáceas.

Psychotria birotula (Figura 27a)

21'. Indivíduos adultos de $6 \mathrm{~m}$ alt.; folhas lanceoladas, cartáceas a subcoriáceas

Psychotria laciniata / Psychotria nuda (Figura 28a)

22. Estípulas com 3,8-5,1 mm compr.

Psychotria gracilenta $($ Figura $27 \mathrm{c})$

22'. Estípulas com 0,8-3,0 mm compr.

23. Folhas rígido-membranáceas a subcoriáceas, oblongas ou lanceoladas, com 7-12 pares de nervuras secundárias, ápice abruptamente acuminado.

Psychotria hoffmannseggiana

23'. Folhas membranáceas, lanceoladas a linear-lanceoladas, com 13-15 pares de nervuras secundárias, ápice longamente acuminado ........ Psychotria leiocarpa (Figura 27d)

24. Nectário extra-floral presente no caule, próximo ao ponto de inserção do pecíolo Callisthene kulhmanii (Figura 31d)

24'. Nectário extra-floral ausente 25

25. Folhas com nervuras acródromas, as terciárias paralelas entre si (Melastomataceae) .................................................................26

$25^{\prime}$. Folhas com outro tipo de nervação ou com nervuras terciárias não paralelas entre si

26. Folhas adultas glabras na face abaxial, exceto por indumento presente às vezes nas nervuras principais 27

26'. Folhas adultas com a face abaxial permanentemente coberta por indumento

27. Nós dos ramos com projeções interpeciolares, à semelhança de estípulas Miconia cinnamomifolia (Figura 16b)

27'. Nós dos ramos sem projeções interpeciolares

28. Folhas com nervuras secundárias suprabasais, unidas na base da nervura central por membrana na face abaxial, margem inteira a denticulada, ápice caudado Miconia hymenonervia

28'. Folhas com nervuras secundárias exclusivamente basais, não unidas na base da nervura central por membrana na face abaxial, margem denticulado-serreada nos $2 / 3$ superiores, ápice longamente caudado Miconia rigidiuscula

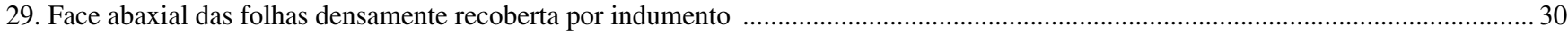

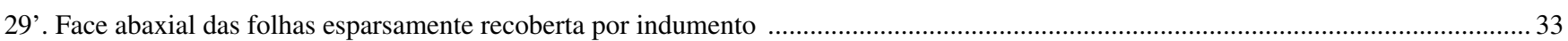

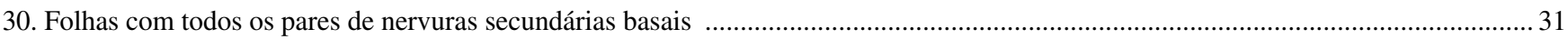

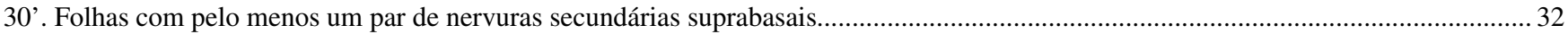

31. Pecíolo com 2,5-8,5 cm compr. e limbo de 9,5-20 × 4-8,5 cm..........Miconia dodecandra (Figura 16d)/Miconia cinerascens (Figura 16a) 31'. Pecíolo com 0,5-2,5 cm compr. e limbo de 4-13 × 1-5 cm Miconia cubatanensis (Figura 16c)

32. Arvoretas com 3-4 m alt.; folhas com 4-13 × 1-4 cm, base atenuada a ligeiramente arredondada ......... Miconia cubatanensis (Figura 16c) 
Anexo 1. Continuação...

32'. Árvores com 5-12 m alt.; folhas com 6-29 × 7-19 cm, base arredondada a subcordada

..Miconia cabussu

33. Folhas adultas com a face adaxial glabra

Miconia saldanhaei (Figura 17a)

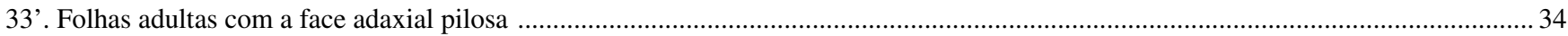

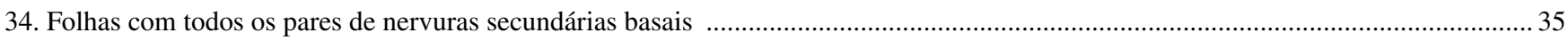

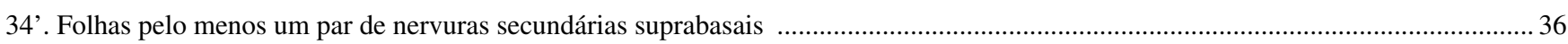

35. Folhas com superfície áspera

Tibouchina weddellii (Figura 17b)

35'. Folhas com superfície lisa

.Tibouchina arborea

36. Folhas adultas com nervura central arroxeada e face adaxial com superfície áspera Leandra scabra(Figura 15d)

36'. Folhas adultas com nervura central com outra coloração e face adaxial com superfície lisa

37. Folhas geralmente com limbo maior ou igual a $15 \mathrm{~cm}$ compr., tricomas ramificados Leandra cf. dasytricha (Figura 15b)

37'. Folhas com limbo de até $11 \mathrm{~cm}$ compr., tricomas simples

38. Ramos com pilosidade híspida; folhas com coloração arroxeada quando secas

Leandra cf. nianga

38'. Ramos com pilosidade adpressa; folhas com coloração não arroxeada quando secas .39

39. Pecíolo com mais de $2 \mathrm{~cm}$ compr.

Leandra cf. dubia (Figura 15c)

39'. Pecíolo com até $1,5 \mathrm{~cm}$ compr.

Tibouchina mutabilis

40. Expansão foliar semelhante a uma estípula (pseudo-estípula) presente

40'. Expansão foliar semelhante a uma estípula (pseudo-estípula) ausente

41. Ramos dicotômicos; folhas lanceoladas

Calyptranthes fusiformis

41'. Ramos não dicotômicos; folhas elípticas

Eugenia brasiliensis

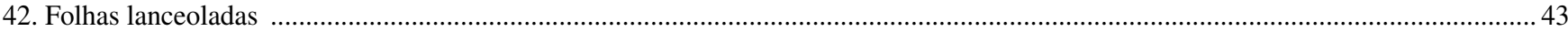

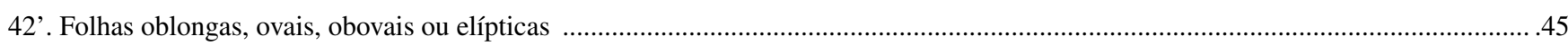

43. Ramos dicotômicos

Calyptranthes strigipes (Figura 20a)

43. Ramos não dicotômicos

44. Ápice da folha longo-acuminado

44'. Ápice da folha agudo, curto-acuminado ou arredondado

Gomidesia spectabilis (Figura 21c)

45. Folhas adultas com $17-30 \mathrm{~cm}$ compr.

45'. Folhas adultas com 2-15 cm compr.

46. Folhas na maioria ovais, glabras

Myrcia heringii

46'. Folhas na maioria oblongas ou elípticas, com indumento

47. Presença de indumento de cor creme, nervuras terciárias inconspícuas na face adaxial

47'. Presença de indumento de cor castanho-avermelhada, nervuras terciárias conspícuas na face adaxial

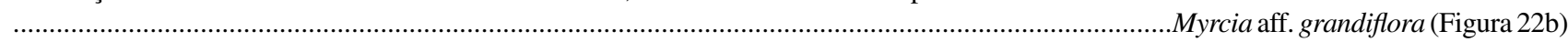

48. Folhas com glândulas translúcidas visíveis apenas sob lente ............................................................................................ 49

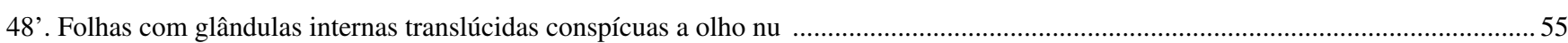

49. Folhas com domácias nas nervuras intramarginais pouco definidas

Campomanesia guaviroba

49'. Folhas com domácias nas nervuras intramarginais bem definidas

50. Ramos dicotômicos

Calyptranthes lucida (Figura 19d)

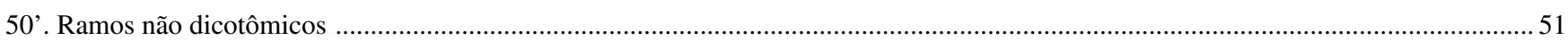

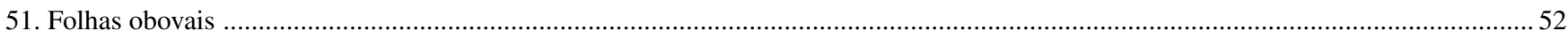

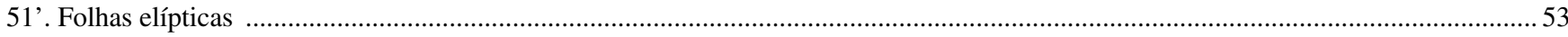




\section{Anexo 1. Continuação...}

52. Látex ausente; folhas com nervuras secundárias pouco visíveis

Psidium cattleianum (Figura 23c)

52'. Látex aquoso presente; folhas com nervuras secundárias visíveis, estreitamente paralelas entre si

Calophyllum brasiliense (Figura 6b)

53. Folhas com nervuras secundárias estreitamente paralelas entre si; presença de látex

Garcinia gardneriana (Figura 6d)

53'. Folhas com nervuras secundárias não paralelas entre si; ausência de látex

54. Folhas com nervuras secundárias conspícuas, nervura intramarginal dupla

Eugenia mosenii (Figura 21a)

54'. Folhas com nervuras secundárias conspícuas, nervura intramarginal dupla

Eugenia cuprea (Figura 20c) / Gomidesia flagellaris

55. Tronco avermelhado 56

55'. Tronco marrom

56. Pecíolos de 0,7-1,1 cm compr. e limbo de 9-11 cm compr.

Eugenia multicostata (Figura 20d)

56'. Pecíolos de 0,2-0,5 cm compr. e limbo de 2-5 cm compr.

Myrcia multiflora (Figura 22c)

57. Ramos dicotômicos

57'. Ramos não dicotômicos

58. Folhas glabras 1,5-4 cm compr., nervuras secundárias estreitamente paralelas entre si.

Blepharocalyx salicifolius

58'. Folhas com indumento 10-14 cm compr., nervuras secundárias não estreitamente paralelas entre si .Calyptranthes grandifolia

59. Folhas curto-pecioladas (pecíolos com até $5 \mathrm{~mm}$ de comprimento)

59'. Folhas longo-pecioladas (pecíolos com mais de $5 \mathrm{~mm}$ de comprimento)

60. Folhas glabras

Eugenia neoaustralis / Eugenia copacabanensis (Figura 20b)

60 '. Folhas com tricomas na face abaxial

Gomidesia schaueriana (Figura 21b)

61. Folhas com glândulas internas visíveis a olho nu mesmo sem olhar contra luz

61'. Folhas com glândulas internas visíveis somente ao olhar contra a luz

62. Glândulas uniformemente distribuídas no limbo foliar, limbo de 10-14 cm compr., ápice longamente acuminado (> $1 \mathrm{~cm})$, folhas adultas glabrescentes

Marlierea eugeniopsoides (Figura 21d)

62'. Glândulas ausentes próximo à nervura central da folha, folhas adultas glabras, limbo com 6-10 cm compr., ápice curtamente acuminado $(\leq 1 \mathrm{~cm})$ Myrcia stictophylla (Figura 23b)

63. Ápice foliar curtamente acuminado $(\leq 1 \mathrm{~cm})$ Myrcia pubipetala (Figura 22d)

63'. Ápice foliar longamente acuminado $(>1 \mathrm{~cm})$

64. Tronco esfoliante fissurado longitudinalmente; folhas com pecíolo sulcado, limbo foliar com 5-7 cm compr., nervura intramarginal distando $1 \mathrm{~mm}$ da margem

Eugenia umbelliflora

64'. Tronco não esfoliante, não fissurado longitudinalmente; folhas com pecíolo não sulcado, limbo foliar com $12-15 \mathrm{~cm}$ compr., nervura intramarginal distando $5 \mathrm{~mm}$ da margem

Eugenia acutata

\section{Chave 4 - Plantas com caule ramificado, folhas simples com disposição alterna}

1. Exsudato translúcido, vermelho ou esbranquiçado

1'. Exsudato ausente

2. Folhas lobadas

2'. Folhas inteiras

3. Folhas não peltadas, com nervação basal

Pourouma guianensis

3'. Folhas peltadas com nervação suprabasal

4. Estípulas vermelho-escuras na face abaxial, com indumento pubescente

Cecropia glaziovii

4'. Estípulas creme-esverdeadas na face abaxial, com indumento tomentoso Cecropia pachystachya

5. Estípulas presentes. 6 
Anexo 1. Continuação...

5'. Estípulas ausentes

6. Estípulas não amplexicaules 7

6'. Estípulas apicais amplexicaules, que deixam cicatriz anelar ao caírem 8

7. Folhas adultas glabras com $6-8 \times 1,8-2,3 \mathrm{~cm}$ Maprounea guianensis (Figura 8b)

7'. Folhas adultas com pilosidade ferrugínea na face abaxial, com 15-23 × 3,5-9 cm

Ecclinusa ramiflora (Figura 29d)

8. Folhas membranáceas ou cartáceas, com nervuras terciárias evidentes na face abaxial

Brosimum glaziovii (Figura 18c) / Brosimum guianense

8'. Folhas coriáceas, com nervuras terciárias inconspícuas na face abaxial 9

9. Pecíolo achatado, folhas com nervação broquidódroma

Ficus pulchella (Figura 18d)

9'. Pecíolo cilíndrico ou levemente sulcado, folhas com nervação eucamptódroma. Coussapoa microcarpa (Figura 31b)

10. Exsudato avermelhado .11

10'. Exsudato esbranquiçado ou incolor

11. Folhas oblongo-lanceoladas, nervuras secundárias imersas na face abaxial, com 8-18 × 2-3,5 cm Virola bicuhyba (Figura 19a)

11'. Folhas oblongas, nervuras nervuras secundárias proeminentes na face abaxial, com 8-18 × 3-8 cm Virola gardneri (Figura 19b)

12. Folhas adultas com pilosidade ferrugínea na face abaxial. Chrysophyllum flexuosum (Figura 29b)

12 '. Folhas adultas glabras ou com tricomas apenas na nervura principal .13

13. Folhas com nervuras secundárias inconspícuas 14

13'. Folhas com nervuras secundárias conspícuas 15

14. Folhas obovais com ápice obtuso ou emarginado Manilkara subsericea

14'. Folhas elípticas com ápice acuminado Diploon cuspidatum (Figura 29c)

15. Folhas com laticíferos em formas de canais evidentes a olho nu na face abaxial Heisteria silvianii (Figura 24c)

15'. Folhas sem laticíferos evidentes na face abaxial

16. Plantas com cicatrizes nos troncos deixadas pela inflorescência cauliflora; folhas adultas com 7,1-22 × 2,8-6,8 cm

Pradosia lactescens (Figura 30a)

16'. Plantas sem cicatrizes nos troncos; folhas adultas com 6-9 $\times 2,3-3,5 \mathrm{~cm}$ Aspidosperma olivaceum (Figura 2a)

17. Folhas com ócrea Coccoloba mosenii

17'. Folhas sem ócrea 18

18. Nós dos ramos espessados .19

18'. Nós dos ramos não espessados

19. Folhas cordadas, base sagitada, com $27-39 \mathrm{~cm}$ compr., pecíolo alado Piper cernuum

19'. Folhas com outros formatos de limbo e base, com 10-18 cm compr., pecíolo não alado

20. Folhas de 5-9 × 10-18 cm, face adaxial glabra

Ottonia martiana (Figura 25c)

20'. Folhas de 3-4,5 $\times 10-15 \mathrm{~cm}$, com tricomas em ambas as faces

Piper aduncum

21. Glândulas lineares internas presentes no limbo foliar, visíveis a olho nu ou com auxílio de lupa 22

21'. Glândulas internas no limbo foliar ausentes ou, se presentes, não lineares

22. Folhas com glândulas lineares translúcidas

Casearia sylvestris

22'. Folhas com glândulas lineares não translúcidas 
Urbanetz, C. et al.

Anexo 1. Continuação...

24. Folhas e ramos ferrugíneo tomentosos, folhas membranáceas, lanceoladas, elíptico-lanceoladas ou oboval-lanceoladas

Myrsine ferruginea

24'. Folhas e ramos glabros, folhas obovais, coriáceas a cartáceas

Myrsine guianensis

25. Folhas alternas dísticas

25'. Folhas alternas espiraladas

26. Folhas lanceoladas, nervuras secundárias pouco evidentes na face abaxial

Xylopia brasiliensis (Figura 1c)

26'. Folhas oblongo-lanceoladas, elípticas ou oblongo-elípticas, nervuras secundárias conspícuas na face abaxial .....

27. Base do pecíolo com cicatrizes semicirculares deixadas por estípulas caducas; folhas com nervação eucamptódroma, folhas elípticolanceoladas.

Lacistema lucidum (Figura 13c)

27'. Base do pecíolo sem cicatrizes semicirculares; folhas com nervação broquidódroma ou, se eucamptódroma, somente na base da folha, folhas elípticas, oblongo elípticas ou oblongo-lanceoladas.

28. Face abaxial da folha com pontuações enegrecidas, vistas com auxílio da lupa Ilexamara (Figura 2b)

28'. Face abaxial da folha sem pontuações enegrecidas 29

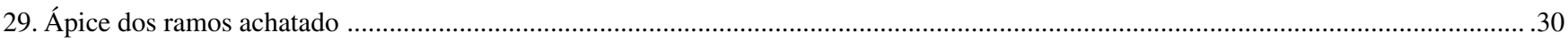

29'. Ápice dos ramos cilíndrico

30. Nervuras secundárias distantes 1-8 mm, terciárias incospícuas ..Heisteria silvianii (Figura 24c)

30’. Nervuras secundárias distantes 6-15 mm, terciárias conspícuas Maytenus schumanniana (Figura 5b)

31. Limbo ou pecíolo com glândulas externas.....

31' Limbo ou pecíolo sem glândulas externas 38

32. Glândulas presentes apenas na base do limbo foliar. 33

32'. Glândulas presentes em todo o limbo foliar ou apenas no pecíolo

33. Folhas com margem inteira

Prunus myrtifolia (Figura 25d)

33'. Folhas com margem serreada 34

34. Folhas com limbo revoluto, orbiculares a ovais, nervura central com 4-5 pares de nervuras secundárias

Alchornea glandulosa $($ Figura 7d)

34'. Folhas com limbo plano, elípticas, lanceoladas a oval-lanceoladas, nervura central com 2-3 pares de nervuras secundárias

Alchornea triplinervia

35. Pecíolo sem glândulas, glândulas presentes nas axilas das nervuras secundárias ou em outras partes do limbo

Aparisthmium cordatum (Figura 8a)

35'. Pecíolo com um par de glândulas, glândulas ausentes nas axilas das nervuras secundárias ou em outras partes do limbo ..... 36

36. Folhas com margem denticulada, glândulas inseridas na parte central do pecíolo que podem ser vistas sem auxílio de lupa

Tetrorchidium rubrivenium (Figura 8d)

36' Folhas com margem inteira, glândulas inseridas na parte distal do pecíolo, próximo à junção da face inferior da lâmina, que podem ser vistas somente com o auxílio de lupa

37. Folhas com 17 nervuras secundárias

Licania octandra (Figura 5d)

37'. Folhas 7-9 nervuras secundárias

38. Folhas com margem serreada

38'. Folhas com margem inteira

39. Plantas arbustivas $(\leq 1,5 \mathrm{~m}$ de alt. e/ou fuste $\geq 0,50 \mathrm{~m})$

Vernonia puberula (Figura 4B) / Vernonia rubriramea / Vernonia beyrichii (Figura 3d)

39'. Plantas arbóreas

40. Folhas adultas lanceoladas, discolores, com superfície da face abaxial não visível, completamente recoberta por indumento 
Anexo 1. Continuação...

40'. Folhas adultas obovais a oboval-elípticas, com superfície da face abaxial visível, apesar da presença do indumento

41. Folhas com estípulas persistentes com 4,5-9 × 1-4,1 mm

Zollernia ilicifolia (Figura 13a)

41'. Folhas sem estípulas

42. Pecíolo canaliculado e tricomas estrelados

42'. Pecíolo circular e com tricomas simples

Symplocos laxiflora (Figura 31a)

43. Pecíolo com espessamento no ápice, presença de glândulas translúcidas circulares no interior do limbo

Esenbeckia grandiflora (Figura 28b)

43'. Pecíolo sem espessamento no ápice, ausência de glândulas translúcidas circulares no interior do limbo

44. Folhas adultas com tricomas na face abaxial

44'. Folhas adultas glabras ou com tricomas apenas na nervura central na face abaxial ......................................................... 57

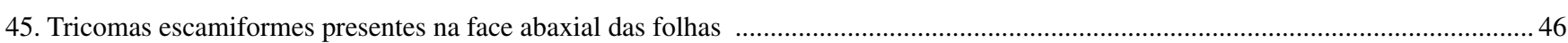

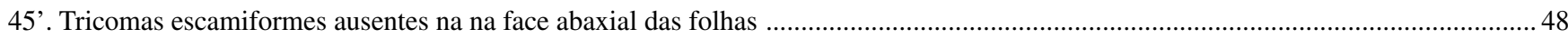

46. Folhas lanceoladas, indumento argênteo ......................................................................................... Solanum swartzianum

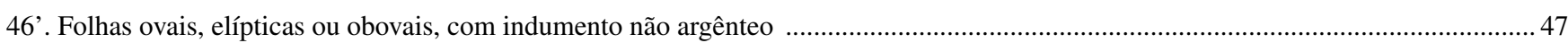

47. Pecíolo cilíndrico de 4,5-10 cm compr., folhas ovais, vermelhas quando velhas, opacas quando frescas

Hyeronima alchorneoides (Figura 25b)

47'. Pecíolo canaliculado de $1 \mathrm{~cm}$ compr., folhas elípticas a obovais, nunca avermelhadas, brilhosas quando frescas

Peraglabrata (Figura 8c)

48. Face abaxial da folha densamente recoberta por indumento

48'. Face abaxial da folha esparsamente recoberta por indumento

49. Arbusto de $1,5 \mathrm{~m}$..

Vernonia argyrotrichia

49'. Árvores adultas com mais de 1,5 m.

50. Pecíolo canaliculado de $2,5-3 \mathrm{~cm}$, na maioria ovais ou elípticas, tricomas estrelados

Piptocarpha macropoda (Figura 3c)

50’. Pecíolo cilíndrico de 1,0-1,4 cm, na maioria elíptico-lanceoladas, tricomas simples

Vernonia petiolaris (Figura 4a)

51. Pecíolo canaliculado, folhas na maioria obovais, concentradas no ápice dos ramos, tricomas estrelados....

Clethra scabra

51'. Pecíolo canaliculado ou não, folhas lanceoladas, elípticas ou ovais, mas se obovais, não concentradas nos ápices dos ramos, tricomas não estrelados

52. Plantas arbustivas $(\leq 1,5 \mathrm{~m}$ de alt. e/ou fuste $\geq 0,50 \mathrm{~m})$

52'. Plantas arbóreas

53. Folhas lanceoladas, cartáceas. Vernonia puberula (Figura 4b)/ Vernonia rubriramea / Vernonia beyrichii (Figura 3d)

53'. Folhas ovais, membranáceas Vernonia scorpioides

54. Folhas elíptico-lanceoladas, ápice e base agudos .55

54'. Folhas ovais, obovais ou oblongas, ápice obtuso, agudo, acuminado ou mucronado, base arredondada 56

55. Pecíolo sem espessamento na base, folha com indumento ferrugíneo na face abaxial. Ocotea nectandrifolia

55'. Pecíolo com espessamento na base, folhas com indumento de cor creme na face abaxial .Cordia sellowiana (Figura 5a)

56. Folhas com estípulas laterais, lineares, ovais ou elípticas, pecíolos de 0,4-0,8 cm compr. Hirtella hebeclada (Figura 5c)

56'. Folhas sem estípulas, obovais ou elípticas, pecíolos de 1,3-3 cm compr. Rhodostemonodaphne macrocalyx

57. Folhas obovais

57'. Folhas com outros formatos 62

58. Face abaxial da folha com pontuações negras Baccharis singularis 


\section{Anexo 1. Continuação...}

58 '. Face abaxial da folha sem pontuações negras

59. Folhas curto-pecioladas $(<0,6 \mathrm{~cm})$, membranáceas

Daphnopsis schwackeana

59’. Folhas longo-pecioladas $(\geq 1 \mathrm{~cm})$, coriáceas

60. Pecíolo de até $1 \mathrm{~cm}$, limbo com mais de $18 \mathrm{~cm}$ compr.

Cordia magnoliifolia (Figura 4d)

60'. Pecíolo maior que $1,5 \mathrm{~cm}$, limbo com menos de $18 \mathrm{~cm}$ compr.

61. Folhas dispostas ao longo de todo o ramo, com 3-11,5 × 1,5-5,5 cm, ápice agudo, apiculado, obtuso ou emarginado

Ilex theezans (Figura 2c)

61'. Folhas concentradas nos ápices dos ramos, com 14-18 × 4-6,5 cm, ápice obtuso

Richeria grandis (Figura 25a)

62. Parte central do pecíolo com um par de glândulas. Tetrorchidium rubrivenium (Figura 8d)

62'. Pecíolo sem glândulas

63. Ramos angulosos alados; folhas aos pares, desiguais na forma e no tamanho Solanum undulatum

63'. Ramos cilíndricos; folhas isoladas não apresentando grandes dimorfismos

64. Ramos com casca esfoliantes

Brunfelsia pauciflora (Figura 30b)

64'. Ramos com casca não esfoliantes

65. Folhas com domácias Solanum pseudoquina (Figura 30d)

65'. Folhas sem domácias

66. Ramos jovens e folhas com pecíolos nigrescentes, ápice foliar acuminado a caudado

Ocotea diospyrifolia (Figura 14c)

66'. Ramos jovens e follhas com pecíolos não nigrescentes, ápice foliar nunca caudado

67. Margem do limbo ondulada, nervuras secundárias pouco evidentes

Ouratea parviflora (Figura 24b)

67'. Margem do limbo não ondulada, nervuras secundárias evidentes

68. Folhas não aromáticas

68'. Folhas aromáticas

69. Plantas arbustivas $(\leq 1,5 \mathrm{~m}$ de alt. e/ou fuste $\geq 0,50 \mathrm{~m})$; folhas ovais a lanceoladas.

Cestrum sessiliflorum (Figura 30c)

69'. Plantas arbóreas; folhas elípticas ou ovais

70. Árvores com até 30,0 m alt.; folhas elípticas ou ovais, com ápice acuminado, brilhosas quando frescas ... Vantanea compacta (Figura 13b) 70’. Arvoretas com até 2,5 m alt.; folhas elípticas, com ápice agudo, opacas quando frescas

71. Estípulas caducas Actinostemon concolor (Figura 7c)

71 '. Estípulas persistentes Erythroxylum cuspidifolium (Figura 7b)

72. Folhas lanceoladas Ocotea daphnifolia

72'. Folhas com outros formatos

......Aniba firmula (Figura 13d) / Cryptocarya saligna (Figura 14a)/Licaria armeniaca / Ocotea aciphylla / Ocotea silvestris (Figura 14d) 